\title{
Asymmetric Catalytic Ketimine Mannich Reactions and Related Transformations
}

\author{
Changgong $X u^{1}$, Carlyn Reep ${ }^{1}$, Jamielyn Jarvis ${ }^{1}$, Brandon Naumann ${ }^{1}$, Burjor Captain ${ }^{2}$ and Norito Takenaka ${ }^{1, *}$ \\ 1 Chemistry Program, Department of Biomedical and Chemical Engineering and Sciences, Florida Institute of \\ Technology, 150 West University Boulevard, Melbourne, FL 32901-6975, USA; cxu2013@my.fit.edu (C.X.); \\ creep2014@my.fit.edu (C.R.); jjarvis2019@my.fit.edu (J.J.); bnaumann2019@my.fit.edu (B.N.) \\ 2 Department of Chemistry, University of Miami, 1301 Memorial Drive, Coral Gables, FL 33146-0431, USA; \\ captain@miami.edu \\ * Correspondence: ntakenaka@fit.edu
}

Citation: Xu, C.; Reep, C.; Jarvis, J.; Naumann, B.; Captain, B.; Takenaka, N. Asymmetric Catalytic Ketimine Mannich Reactions and Related Transformations. Catalysts 2021, 11, 712. https://doi.org/10.3390/ catal11060712

Academic Editors: Jae-Sang Ryu and Bimal Krishna Banik

Received: 21 May 2021

Accepted: 5 June 2021

Published: 7 June 2021

Publisher's Note: MDPI stays neutral with regard to jurisdictional claims in published maps and institutional affiliations.

Copyright: (c) 2021 by the authors. Licensee MDPI, Basel, Switzerland. This article is an open access article distributed under the terms and conditions of the Creative Commons Attribution (CC BY) license (https:// creativecommons.org/licenses/by/ $4.0 /)$.

\begin{abstract}
The catalytic enantioselective ketimine Mannich and its related reactions provide direct access to chiral building blocks bearing an $\alpha$-tertiary amine stereogenic center, a ubiquitous structural motif in nature. Although ketimines are often viewed as challenging electrophiles, various approaches/strategies to circumvent or overcome the adverse properties of ketimines have been developed for these transformations. This review showcases the selected examples that highlight the benefits and utilities of various ketimines and remaining challenges associated with them in the context of Mannich, allylation, and aza-Morita-Baylis-Hillman reactions as well as their variants.
\end{abstract}

Keywords: ketimine Mannich; ketimine allylation; aza-Morita-Baylis-Hillman; asymmetric catalysis; $\alpha$-tertiary amine; $\beta$-amino carbonyl

\section{Introduction}

The condensation reaction between in situ generated imines and enols to form $\beta$ amino carbonyl compounds was reported by Carl U. F. Mannich for the first time in 1912 [1]. This is the transformation that is widely known as the Mannich reaction today. Since it provides direct access to synthetically useful chiral building blocks from readily available carbonyls and amines, it attracted huge attention from the synthetic community and is now recognized as one of the most important chemical transformations (selected reviews; [2-12]). In order to circumvent the inherent difficulties associated with the classical Mannich reaction such as regio-, stereo-, and product-selectivities, preformed imines and/or enolates have often been employed. These nonclassical Mannich variants are broadly regarded as the Mannich reaction while they are alternatively called the Mannichtype reaction, aza- or imino-aldol reaction to be more specific. However, distinction between these terminologies largely remains dependent on an individual author; thus, the term "Mannich reaction" is used for all Mannich-type transformations covered in this review for clarity unless otherwise stated.

Over the years, the asymmetric catalytic Mannich reaction of ketimines (Scheme 1) has been of significant interest to synthetic and medicinal chemists as a way to access synthetically versatile compounds bearing an $\alpha$-tertiary amine stereogenic center (selected reviews; [13-23]). It is because optically pure chiral $\alpha$-tertiary amines are a key structural motif found in a large number of biologically relevant molecules and natural products (Figure 1) [24-28]. However, ketimines are much more challenging electrophiles than aldimines for the Mannich and its related reactions (e.g., allylation) due to some notorious structural properties of the formers (Figure 2). In general, diaryl, aryl alkyl, and dialkyl ketimines (i.e., unmodified ketimines) are poor electrophiles because of the severe steric demands and the electron-donating nature of the two groups flanking a $\mathrm{C}=\mathrm{N}$ bond. Furthermore, these two substituents on a prochiral center are structurally similar thus difficult to distinguish by a chiral catalyst, often leading to low stereoselectivities. 


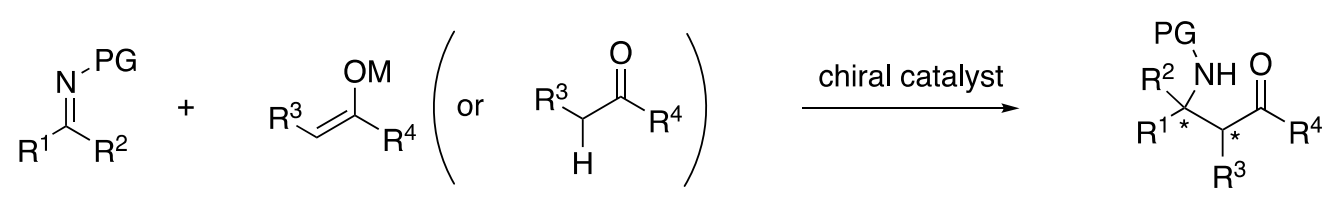

$P G=$ protecting group, $M=$ metals, $\mathrm{Si}, \mathrm{B}$, etc .

Scheme 1. Asymmetric catalytic ketimine Mannich reaction.<smiles>COc1cccc(-c2cccc(CC[C@@]3(C)CC(=O)N(C)C(N)=N3)c2)c1</smiles>

(R)- $\beta$-secretase inhibitor<smiles>CC[C@@](C/C=C/c1ccccc1)(c1ccccc1)N(C)CC1CC1</smiles>

(+)-igmesine

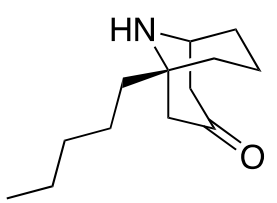

(-)-adaline<smiles>COC(=O)N1c2ccc(OC)cc2C23CCN4CCCC45CCC12CC53</smiles>

(-)-lundurine C<smiles>CN[C@H]1CN2[C@@H](Cc3ccc(OC)cc3)[C@H](O)C3CC2(CCC3OP(=O)(O)O)C1</smiles>

(-)-FR901483

Figure 1. Examples of bioactive compounds and natural products bearing an $\alpha$-tertiary amine stereogenic center.

- Low reactivity due to severe steric demands and electron-donating nature of $R^{1} \& R^{2}$.

- Structural similarity of $R^{1}$ and $R^{2}$ that are difficult to distinguish by a chiral catalyst.

- Presence of $E / Z$ isomers that could diminish the stereoselectivities of a reaction.

- Rapid tautomerization to unreactive enamines under basic conditions.<smiles>[3H]C=N[Pb]</smiles>

E-aldimines<smiles>[R]C(C)=NO</smiles>

electrophile<smiles>[R7]C([R7])=N[Po]</smiles>

E-ketimines<smiles>[R7]C([R7])=N[Pb]</smiles>

Z-ketimines

$$
\mathrm{R}^{1}=\mathrm{R}^{2}=\text { aryl and/or alkyl; } \mathrm{PG}=\mathrm{Boc}, \mathrm{PMP}, \mathrm{Bn}, \mathrm{P}(\mathrm{O}) \mathrm{Ph}_{2} \text {, Ts, etc. }
$$

Figure 2. Notorious properties of unmodified ketimines as electrophiles.

Nonendocyclic ketimines can equilibrate between the $E$ and $Z$ forms in solution at room temperature by an inversion, or rotation, and furthermore, through ketimineenamine tautomerization, if they have an $\alpha$-hydrogen atom [29]. Therefore, ketimines are often available only as a mixture of $E$ and $Z$ isomers that could lead to diminished 
<smiles>CC(CCc1ccccc1)=NNC(=O)c1ccccc1</smiles>

pure $E$ or a 3.8:1 E:Z mixture

stereoselectivities in the asymmetric transformations. An interesting observation regarding the $E / Z$ isomerism was reported by Leighton and coworkers in 2004 (Scheme 2) [30]. Their chiral allylation reagent provided the homoallylic amine in the same yield and ee regardless of the $E / Z$ isomeric ratio of the ketimine used. It was presumed that the ketimine isomerized under the reaction conditions, and one isomer selectively underwent the allylation reaction. Despite this observation, it remains largely elusive how to logically develop such catalytic enantioselective methods. Alternatively, catalytic methods that tolerate $N$-unsubstituted ketimine salts, thus obviating the $E / Z$ isomerism, have been developed in recent years [31]. In 2009, Gosselin, Zhang, and coworkers reported the first examples of catalytic hydrogenation of $\mathrm{N}$-unsubstituted ketimine salts (not shown) [32]. These reported examples bode well for the further development of ketimine Mannich and related transformations.

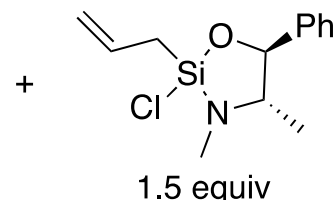

1.5 equiv

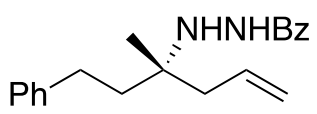

with pure $E$ : $86 \%$ yield, $87 \%$ ee with a $E: Z$ mixture: $87 \%$ yield, $87 \%$ ee

Scheme 2. Selected example of in situ $E / Z$ isomerization of ketimine.

The majority of the work published on the ketimine Mannich reaction and its related transformations employed ketimines where some notorious properties of unmodified ketimines summarized in Figure 2 were absent. In this mini-review, unmodified ketimines refer to nonendocyclic ketimines in which no electron-withdrawing groups and/or alkynes are attached to the carbon atom of a $\mathrm{C}=\mathrm{N}$ bond (sp hybridized carbon atoms are electronegative; for example, the $\mathrm{p} K_{\mathrm{a}}$ value of acetylene is 24 in $\mathrm{H}_{2} \mathrm{O}$ ). Therefore, this review is organized based on the structures of ketimines under each reaction class. It is arguable whether ketimines bearing strongly electron-withdrawing $N$-protecting groups such as $\mathrm{N}$-tosyl ketimines should be categorized as unmodified ketimines or not; however, they are also included as part of unmodified ketimines as long as those ketimines are tautomerizable. Where appropriate, each ketimine class is further classified based on the kind of nucleophiles and/or the methods to generate them. The objective of this review is to highlight the benefits and utilities of different ketimines and remaining challenges associated with them in the context of Mannich, allylation, and aza-Morita-Baylis-Hillman reactions as well as their variants. We hope the information provided herein promotes the study and use of ketimines that are in general considered problematic substrates. Only a summary of the results is shown in each case to focus on the objective, unless otherwise noted. Interested readers may want to refer to the corresponding literature for the detailed catalytic mechanisms and the stereochemical models that are usually provided therein.

In this review, selected examples published over the past decade or so and some pioneering works are covered. With respect to the transformations related to the ketimine Mannich reaction, only methods that employ enolates or its equivalents (e.g., silyl enol ethers and allyl metals) as nucleophiles to provide $\beta$-amino carbonyl compounds or its equivalents are covered, while vinylogous Mannich reactions are included. The asymmetric catalytic methods of ketimines that provide $\alpha$-amino carbonyl compounds such as Strecker reaction (selected review; [33]), nitro-Mannich reaction (selected review; [34]), aza-benzoin reaction (selected references [35,36]) are not included. The asymmetric umpolung addition of ketimines to electrophiles (selected references; [37-44]) is beyond the scope of this review. Oxidative asymmetric Mannich reaction is an approach to avoid some drawbacks of preformed ketimines by in situ oxidation of corresponding amines, which is recently reviewed [45]. Interested readers may wish to refer to these selected articles. 


\section{Activated and/or Cyclic Ketimines in the Mannich Reaction}

\subsection{Endocyclic Ketimines with Electron-Withdrawing Substituents}

\subsubsection{The First Examples of Catalytic Enantioselective Ketimine Mannich Reactions}

In 2003, Jørgensen and coworkers described their approach toward the first catalytic enantioselective ketimine Mannich reaction (Scheme 3) [46]. They designed and developed the endocyclic aryl ketiminoesters (1) that circumvented the poor electrophilicity, the structural similarity of two groups flanking a $\mathrm{C}=\mathrm{N}$ bond, the tautomerization, and the $E / \mathrm{Z}$ isomerism associated with unmodified ketimines. They evaluated their ketiminoesters for the Mukaiyama-Mannich reaction (2) and obtained the products in 86-99\% yields with $34-95 \%$ ee. In a subsequent year, they reported the application of the same ketiminoesters for direct organocatalytic enantioselective Mannich reaction that provided the corresponding products in $82-99 \%$ yields with 4:1->20:1 diastereoselectivities and $72-98 \%$ ee (3) [47]. It is worthy of note that these ketimines reacted well with catalytically generated enamines in the presence of small aldehydes such as propionaldehyde (i.e., good electrophiles). The two consecutive reports clearly demonstrated that these endocyclic tautomerization-free ketiminoesters were viable substrates for the enantioselective catalytic Mannich reactions via either the electrophile activation (i.e., Lewis acid catalysis) or the nucleophile activation (i.e., Lewis base catalysis) methods to access chiral synthetic building blocks bearing an $\alpha$-tertiary amine stereogenic center, inspiring the later developments.

(1)<smiles></smiles>

1) $\mathrm{O}=\mathrm{C}=\mathrm{N}^{\prime}$ DIPEA (cat)

2) $\mathrm{HCO}_{2} \mathrm{H}$
$\mathrm{R}^{1}=\mathrm{H}, 68 \%$ yield<smiles>CCOC1(O)NC(=O)Oc2ncccc21</smiles><smiles>CCOC1(O)NC(=O)Oc2ncccc21</smiles>

$\mathrm{R}^{1}=\mathrm{H}, \mathrm{Me}, \mathrm{OMe}, \mathrm{F}, \mathrm{Cl}$

\section{PMB}<smiles>C=C(C(=O)OCC)C1=CC2C=CC=CC1[In]=C2</smiles>

$\mathrm{R}^{1}=\mathrm{H},>99 \%$ yield

(2)<smiles></smiles><smiles>COc1ccc(OC)c(OC)c1C</smiles>

1.2 equiv

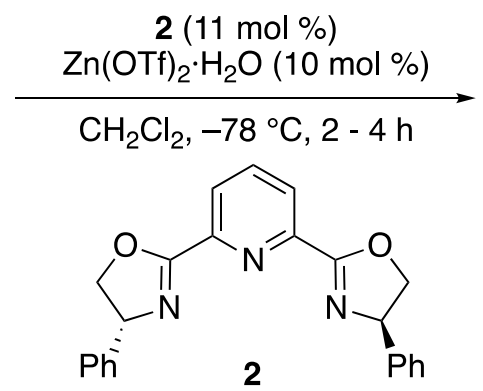

2<smiles>CCOC(=O)C(C)(C)[C@]1(C(=O)OCC)NC(=O)Oc2cccn21</smiles>

7 examples $86-99 \%$ yields $34-95 \%$ ee

(3)

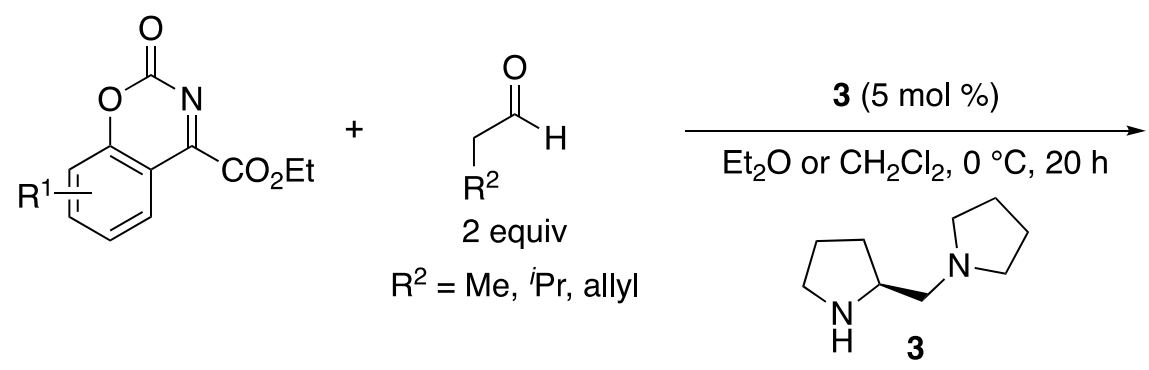

Scheme 3. The first asymmetric catalytic ketimine Mannich reactions. 


\subsubsection{Direct Mannich}

In 2012, Kano, Maruoka, and coworkers developed synthetically flexible ketiminoester 4 and demonstrated its utility in direct organocatalytic enantioselective ketimine Mannich reactions (Scheme 4) [48]. More specifically, they designed an easy-to-prepare nonaromatic ketiminoester that provides relatively versatile synthetic building blocks because an ester group is synthetically more flexible than an aryl group in general. As 4 is relatively reactive, it is a convenient electrophile to build a chiral $\alpha$-tertiary amine motif into compounds. It is notable that their method is stereodivergent and afforded either syn- or anti- $\gamma$-lactones after subsequent $\mathrm{NaBH}_{4}$ reduction of the aldehyde products in $59-79 \%$ yields with excellent diastereo- and enantio-selectivities (>20:1 and 99\% ee, respectively). L$_{\text {-Proline and axial }}$ chiral anime 5 afforded syn- and anti- $\gamma$-lactones, respectively.

(1)
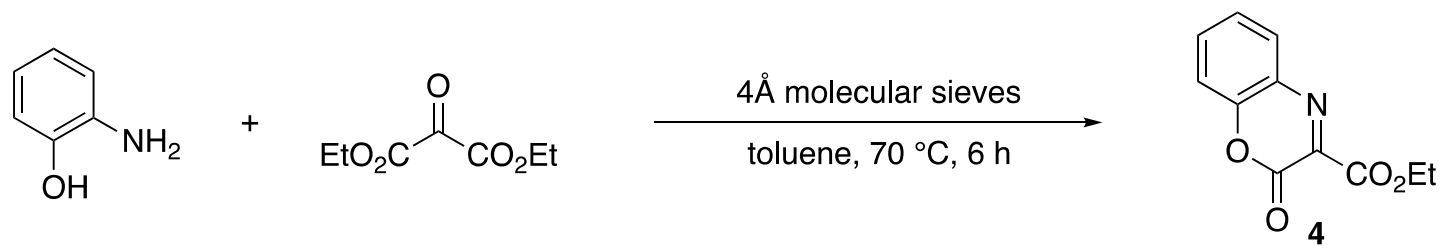

$94 \%$ yield

(2)<smiles>CCOC(=O)c1nc2ccccc2oc1=O</smiles><smiles>O=CCC=S</smiles>

$\mathrm{R}=\mathrm{Et}, \mathrm{Bu}, \mathrm{Hex}$ $\mathrm{Bn}, \mathrm{CH}_{2} \mathrm{Cy}$

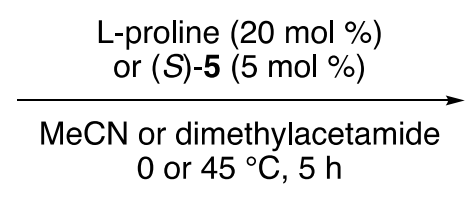<smiles>CCNc1ccc(OC)c2c1CNCC2</smiles>

(S) -5<smiles>CCOC(=O)C1CCOC1=O</smiles>

"

syn

5 examples

$62-72 \%$ yields

d.r. $=>20: 1$

$99 \%$ ee or<smiles>CCOC(=O)C1C(=O)OCC1Nc1ccccc1O</smiles>

anti

5 examples $59-79 \%$ yields

d.r. $=>20: 1$

$99 \%$ ee

Scheme 4. Stereodivergent direct catalytic asymmetric Mannich reaction of an endocyclic ketiminoester.

Endocyclic $N$-sulfonyl ketiminoesters have often been employed in catalytic asymmetric Mannich reactions because resulting chiral benzosultams are an important structural motif present in many medicinally important molecules, and this class of ketimines is relatively easy substrates to work with (highly electrophilic, no tautomerization, and no $E / Z$ isomer issues). As such, we discuss selected examples in Scheme 5 and 10 (for other selected examples; see [49-53]).

In 2015, Ma and coworkers developed a highly regio-, diastereo- and enantio-selective Mannich reaction of $\beta, \gamma$-unsaturated ketones with $N$-sulfonyl ketiminoesters by employing a saccharide-derived tertiary amino-thiourea catalyst (Scheme 5) [54]. The reaction scope was found broad in allylic ketones and included aryl, heteroaryl, alkenyl, benzyl, and alkyl allyl ketones, affording the corresponding products in $45-99 \%$ yields with 1.5:1->20:1 diastereoselectivities and 77-97\% ee. The $\beta, \gamma$-unsaturated-ketone products did not isomerize to the corresponding $\alpha, \beta$-unsaturated ketones, which highlighted the mildness of the reaction conditions. It is noteworthy that benzyl allyl ketone provided a desired regioisomer in $64 \%$ yield. 
<smiles>CCOC(=O)C1=NS(=O)(=O)c2ccccc21</smiles>

$R^{1}=M e, F$, etc<smiles>[R]C(=O)CC=C</smiles>

$\mathrm{R}^{2}=$ aryl, heteroaryl, alkenyl, Bn, alkyl

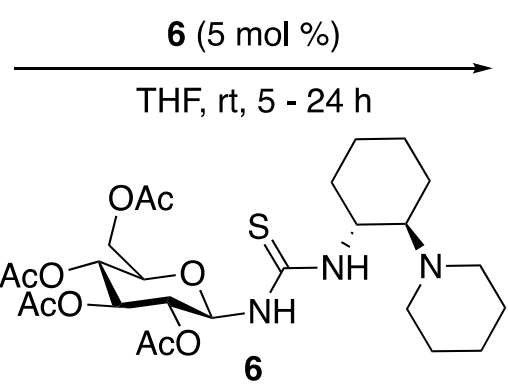<smiles>[R2]C(=O)[C@H](C=C)[C@@]1(COCC)NS(=O)(=O)c2ccc[R1]c21</smiles>

25 examples $45-99 \%$ yields d.r. $=1.5: 1->20: 1$ ee $=77-97 \%$

Scheme 5. Regioselective asymmetric Mannich reaction of allylic ketones with $N$-sulfonyl ketiminoester.

Chiral dihydroquinazolinones are one of the important motifs found in biologically relevant molecules. Since the catalytic asymmetric Mannich reaction of dihydroquinazolines provides direct access to enantio-enriched dihydroquinazolinones and dihydroquinazolines are relatively reactive ketimines, many contributions have been reported, which highlight the usefulness of the asymmetric Mannich reaction of dihydroquinazolines for medicinal chemistry. We discuss two selected examples herein (for other selected examples, see [55-57]).

In 2017, Enders and coworkers developed an enantioselective oxidative NHC-catalyzed $[4+2]$ annulation reaction of $\beta$-methyl enals and trifluoromethyl dihydroquinazolines (Scheme 6) [58]. The catalytically generated dienolate proved highly effective for addition to trifluoromethyl dihydroquinazolines, providing heterocyclic dihydroquinazolinone derivatives bearing a trifluoromethyl group and a tetrasubstituted stereogenic center in $42-85 \%$ yields with $87: 13-98.5: 1.5$ enantiomeric ratios.<smiles>[R]/C(C=O)=C/C=[Co]</smiles>

$\mathrm{R}^{1}=\mathrm{Me}, \mathrm{F}, \mathrm{Cl}$
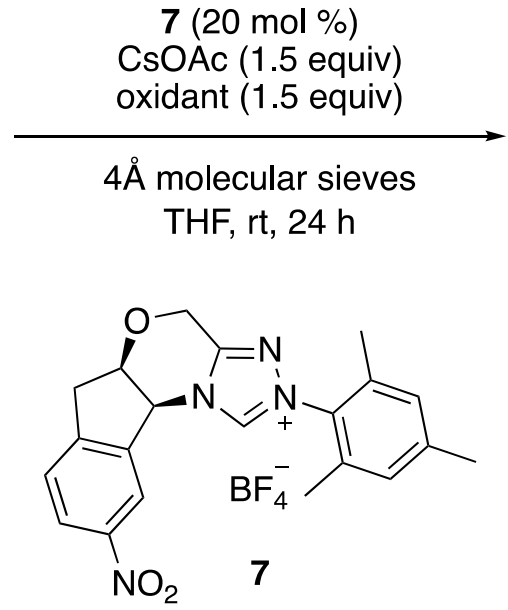<smiles>[R7]C1=CC(=O)N2C(=O)N([R15])c3ccc([R])cc3[C@]2(C)C1</smiles>

17 examples

$42-85 \%$ yields

e.r. $=87: 13-98.5: 1.5$<smiles>CCC(C)C1=CC(=C2C=C(C(C)C)C(=O)C(C(C)(C)C)=C2)C=C(C(C)C)C1=O</smiles>

Scheme 6. The oxidative NHC-catalyze [4 +2] annulation reaction of enals and dihydroquinazolines.

In 2018, Xu, Yuan, and coworkers developed a diastereo- and enantio-selective catalytic Mannich reaction of pyrazoleamides with trifluoromethyl dihydroquinazolines by employing a bifunctional cinchona-derived squaramide catalyst (Scheme 7) [59]. The method provided a wide range of trifluoromethyl dihydroquinazolinone derivatives bearing adjacent tertiary and quaternary stereogenic centers in 17-99\% yields with $>20: 1$ diastereoselectivity and $85-99 \%$ ee. It is noteworthy that they successfully demonstrated a multi-mmol scale reaction that provided $1.21 \mathrm{~g}$ of the desired product with no loss in yields and stereoselectivities $\left(\mathrm{R}^{1}=\mathrm{Cl}, \mathrm{Ar}=\mathrm{Ph}, \mathrm{R}^{2}=\mathrm{H}, 91 \%\right.$ yield, $>20: 1$ d.r., $99 \%$ ee). 
<smiles>[R16]n1c(=O)nc(C(F)(F)F)c2cc([Tl])ccc21</smiles>

$\mathrm{R}_{1}=\mathrm{Me}, \mathrm{OMe}$, $\mathrm{Cl}, \mathrm{PMB}$<smiles>[R]c1cc([R2])n(C(=O)C[Al])n1</smiles>

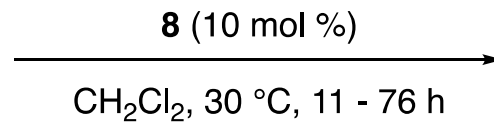

$\mathrm{Ar}=$ aryl, heteroaryl $\mathrm{R}^{2}=\mathrm{H}$ or $\mathrm{Me}$<smiles>C=CC1CCN(C(Nc2c(Nc3cc(C(F)(F)F)cc(C(F)(F)F)c3)c(=O)c2=O)c2ccnc3ccc(OC)cc23)CC1</smiles>

16 examples $17-99 \%$ yields d.r. $=>20: 1$ ee $=85-99 \%$

Scheme 7. Asymmetric Mannich reaction of pyrazoleamides and dihydroquinazolines.

Indole derivatives are privileged structures and thus found in numerous pharmaceutical compounds. Moreover, 2-Aryl-3H-indol-3-ones are valuable synthons for the synthesis of complex indole-derived molecules. This class of ketimines was demonstrated as viable electrophiles in the proline-catalyzed Mannich reactions with aldehydes and ketones by the groups of Xie and Rueping in 2011 and 2012, respectively [60,61] (not shown), highlighting their sufficient electrophilicity.

In 2019, Fu and coworkers developed a chiral phosphoric acid-catalyzed Mannich reaction of 2-aryl-3H-indol-3-ones (10) with Schiff bases generated in situ from aromatic aldehydes and diethyl 2-aminomalonate (Scheme 8) [62]. This method afforded complex heterocycles bearing a nitrogen-substituted quaternary and aminal stereogenic centers that are not trivial to make in 51-71\% yields with >20:1 diastereoselectivities and 21-96\% ee.

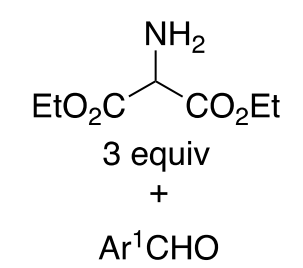

3.3 equiv $\mathrm{Ar}^{1}=4-\mathrm{NO}_{2}-\mathrm{Ph}$, etc.

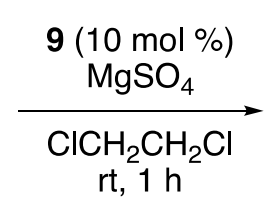<smiles>CCOC(=NC=[Al])C(OCC)OCC</smiles><smiles>O=P(O)(O)Oc1cc(CCCCCCc2ccc(-c3cc4ccccc4c4ccccc34)c(-c3cccc4ccccc34)c2OP(=O)(O)O)ccc1-c1cc2ccccc2c2ccccc12</smiles>

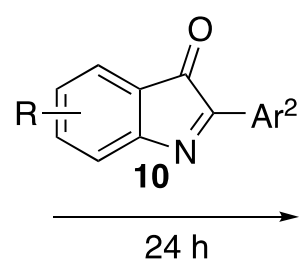

$\mathrm{Ar}^{2}=\mathrm{Ph}, 4-\mathrm{F}-\mathrm{Ph}$, etc. $\mathrm{R}=\mathrm{Me}, \mathrm{F}, \mathrm{Cl}, \mathrm{Br}$<smiles>CCOC(=O)C12C(=O)c3cbccc3N1C([Al])NC2(C)OCC</smiles>

26 examples $51-71 \%$ yields d.r. $=>20: 1$ ee $=21-96 \%$

Scheme 8. Chiral phosphoric acid-catalyzed Mannich reaction of 2-aryl-3H-indol-3-ones.

In 2019, Zheng, Ye, Huang, and coworkers reported a one-pot construction of chiral 2,2-disubstituted 3-iminoindolines (Scheme 9) [63]. In addition, 3-Iminoindoles (11) were generated in situ from amides and isocyanides in $\mathrm{CH}_{2} \mathrm{Cl}_{2}$ for $1 \mathrm{~h}$, and then the resulting 
reaction mixtures were treated with a DMSO solution of ketones, proline and $\mathrm{Et}_{3} \mathrm{~N}$ to provide the Mannich products in 51-79\% yields with $95-99 \%$ ee. This method constructed 3 carbon-carbon bonds, 1 ring, and 1 nitrogen-substituted quaternary stereogenic center in one pot.

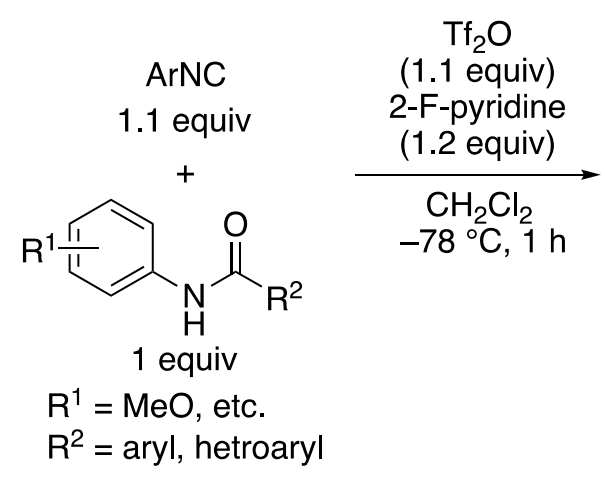<smiles>[R]C1=Nc2cc[Y17]([H])cc2C1=[W]</smiles>

11

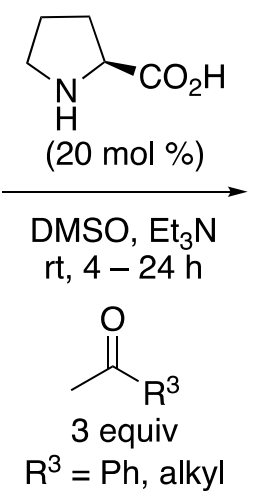<smiles></smiles>

\section{9 examples}

$51-79 \%$ yields ee $=95-99 \%$

Scheme 9. Proline-catalyzed Mannich reaction of 3-iminoindoles generated in situ from amides and isocyanides.

\subsubsection{Preformed Enolate Equivalents}

In 2017, Jia and coworkers reported an enantioselective [2 + 2] cycloaddition of $N$-sulfonyl ketiminoesters with $N$-allenamides that produced chiral azetidines (Scheme 10) [64]. They screened several Lewis acidic metal salts and chiral BOX ligands and then identified Ni-12 complex as an optimal catalyst for this transformation. $N$-Allenyl oxazolidinones were also found to be viable nucleophiles for their method. The reactions with $N$-allenyl oxazolidinones provided the corresponding acrylaldehydes after standard aqueous workup, although it took $3 \mathrm{~h}$ at $60{ }^{\circ} \mathrm{C}$ to hydrolyze azetidines derived from $\mathrm{N}$-allenamides with $\mathrm{TsOH} \cdot \mathrm{H}_{2} \mathrm{O}$. It is noteworthy that only one diastereomer was detected in all cases. The azetidines and acrylaldehydes were obtained in 52-90\% yields with $90-99 \%$ ee and in $44-65 \%$ yields with $83-95 \%$ ee, respectively.

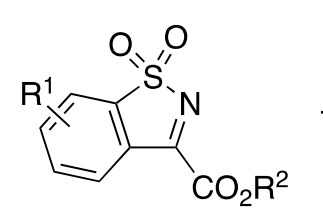

$R^{1}=$ Me, $F$, etc.

$\mathrm{R}^{2}=$ alkyl

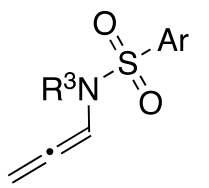

1.5 equiv

$\mathrm{R}^{3}=$ aryl, $\mathrm{Bn}$
$12(12 \mathrm{~mol} \%)$

\begin{tabular}{|c|}
\hline $\mathrm{Ni}\left(\mathrm{ClO}_{4}\right)_{2} \cdot 6 \mathrm{H}_{2} \mathrm{O}(10 \mathrm{~mol} \%)$ \\
\hline $4 \AA ̊$ molecul \\
\hline
\end{tabular}<smiles>CC(C)(C1=N[C@@H](c2ccccc2)CO1)C1=N[C@@H](c2ccccc2)CO1</smiles>

12<smiles></smiles>

single diastereomers

$$
\begin{aligned}
& 26 \text { examples } \\
& 52-90 \% \text { yields } \\
& \text { ee }=90-99 \%
\end{aligned}
$$

or

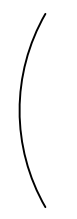

single diastereomers

5 examples

$44-65 \%$ yields

ee $=83-95 \%$

Scheme 10. Enantioselective [2 + 2] cycloaddition of $N$-allenamides with $N$-sulfonyl ketiminoester. 


\subsection{Endocyclic Ketimines without Electron-Withdrawing Substituents}

All of the notorious properties of unmodified ketimines summarized in Figure 2 are absent in the ketimines discussed above. However, these contributions clearly demonstrated that creative applications of relatively easy-to-use ketimines for Mannich reaction can provide synthetically versatile and medicinally important $\beta$-amino carbonyl compounds and their variants that are otherwise difficult to synthesize. In this section, endocyclic ketimines that are not substituted with electron-withdrawing substituents at their $\mathrm{C}=\mathrm{N}$ carbon atoms are discussed. These ketimines are less electrophilic and thus, arguably, more challenging substrates.

\subsubsection{Direct Mannich}

3-Aryl-3-hydroxyisoindolin-1-ones are often employed as stable precursors for the corresponding endocyclic $\mathrm{N}$-carbonyl diaryl ketimines. This class of ketimines is useful synthons to access chiral isoindolin-1-ones that are an important motif found in numerous biologically relevant molecules and natural products. In 2019, Reddy and coworkers reported BINOL phosphoric acid-catalyzed Mannich reaction of endocyclic $N$-acyl ketimines generated in situ from 3-hydroxyisoindolin-1-ones (Scheme 11) [65]. The method provided chiral isoindolin-1-ones bearing adjacent quaternary and tertiary stereogenic centers in $83-95 \%$ yields with excellent stereoselectivities despite the high reaction temperature (99:1 diastereoselectivity for all substrates and 77-97\% ee). They noted that 3-hydroxy3-pentylisoindoline-1-one (i.e., a tautomerizable ketimine) provided the corresponding enamide in $95 \%$ in $4 \mathrm{~h}$ without the desired Mannich product under the optimized condition.<smiles>O=C1NC(O)([14Cl])c2ccccc21</smiles>

$\operatorname{Ar}=$ aryl, heteroaryl<smiles>[R]C1=CC(=O)CCC1([R])[2H]</smiles>

1.5 equiv

$$
\mathrm{R}=\mathrm{H} \text { or } \mathrm{Me}
$$

$13(10 \mathrm{~mol} \%)$

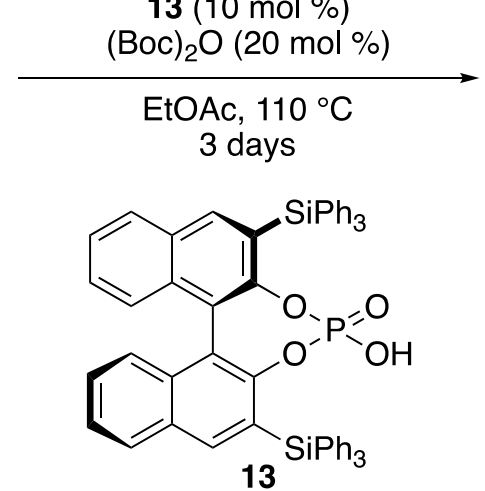<smiles>[R]C1=CC(=O)C([C@]2([Al])NC(=O)c3ccccc32)CC1([R])[R]</smiles>

17 examples $83-95 \%$ yields d.r. $=99: 1$ ee $=77-97 \%$

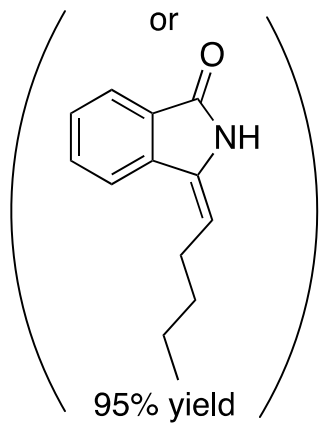<smiles>CCCCCC1(O)NC(=O)c2ccccc21</smiles>

Scheme 11. BINOL phosphoric acid-catalyzed Mannich reaction of endocyclic $N$-acyl ketimines.

In 2013, Wang and coworkers described the proline-catalyzed direct asymmetric Mannich reaction of 3-substituted-2H-1,4-benzoxazines (Scheme 12) [66]. This work represents the first catalytic asymmetric Mannich reaction of 3,4-dihydro-2H-1,4-benzoxazines and provided the $N$-heterocyclic products in $48-94 \%$ yields with $61->99 \%$ ee. The authors pointed out that the ring strain in 3,4-dihydro- $2 \mathrm{H}-1,4$-benzoxazines contributed to their reactivities. It is still notable that these ketimines bear no electron-withdrawing substituents 
in sharp contrast to the ketimines discussed earlier in this review. It is worthy of mention that the same transformation catalyzed by wheat germ lipase was reported by Guan, He, and coworkers in 2016 (not shown) [67].<smiles>[R]=[Pt]C1=Nc2cc[14cH]cc2OC1</smiles>

$\mathrm{Ar}=$ aryl, alkenyl $\mathrm{R}=\mathrm{Me}, \mathrm{F}, \mathrm{Cl}, \mathrm{NO}_{2}$<smiles>O=C(O)[C@H]1CCCN1</smiles>

$(10 \mathrm{~mol} \%)$

DMSO, rt, $48-72 \mathrm{~h}$
10 equiv<smiles>[R][R]1ccc2c(c1)N[C@@]([125I])(CC(C)=O)CO2</smiles>

16 examples $48-94 \%$ yields ee $=61->99 \%$

Scheme 12. Proline-catalyzed Mannich reaction of 3-substituted-2H-1,4-benzoxazines.

$2 \mathrm{H}$-Azirines are three-membered ring molecules with a $\mathrm{C}=\mathrm{N}$ double bond and are the most strained nitrogen unsaturated heterocyclic compounds (selected review; [68]). Their high chemical reactivity is mainly due to their high ring strain that enhances the reactivity of the $\mathrm{C}=\mathrm{N}$ bond.

In 2018, Lin, Feng, and coworkers developed a copper-catalyzed asymmetric Mannich reaction of $2-H$-azirines with $\beta$-keto amides (Scheme 13) [69]. This represents the first example of the catalytic enantioselective Mannich reaction of $2-H$-azirines and is one of the two early examples of asymmetric catalytic additions of carbon-based nucleophiles to 2-Hazirines (the aza-benzoin reaction of aldehydes with $2-H$-azirines was reported earlier in the same year) [35]. This method employed racemic 2- $H$-azirines; one enantiomer of which preferentially reacted with a chiral $\mathrm{Cu}$-enolate complex, affording the aziridines bearing three contiguous stereogenic centers in 65-99\% yields with 45:55-91:9 diastereoselectivities and 32-94\% ee.
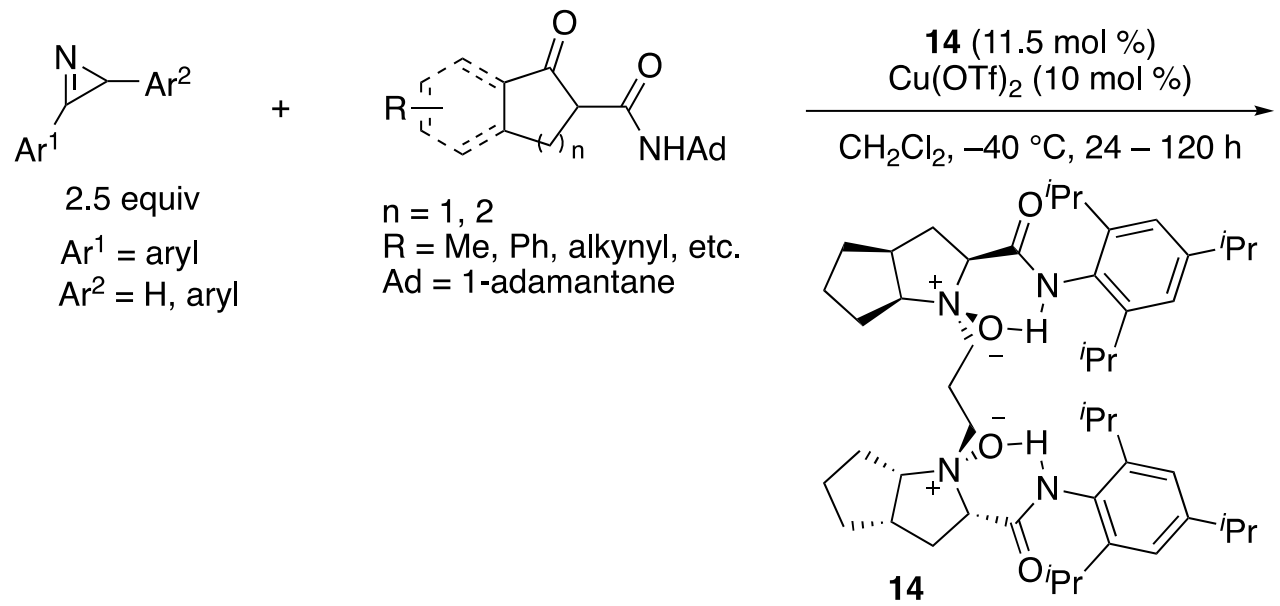

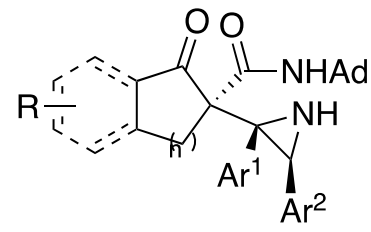

32 examples $65-99 \%$ yields d.r. $=45: 55-91: 9$ 32 - $94 \%$ ee

Scheme 13. Copper-catalyzed asymmetric Mannich reaction of $2 H$-azirines with $\beta$-ketoamides.

In 2019, Yin and coworkers reported a copper(I)-catalyzed asymmetric decarboxylative Mannich reaction of $2 \mathrm{H}$-azirines (Scheme 14) [70]. This method utilized a $2 \mathrm{H}$-azirine not only as an electrophile but also as a base to deprotonate a cyanoacetic acid to induce its decarboxylation (i.e., decarboxylative enolization). As such, a reacting electrophile was a protonated $2 \mathrm{H}$-azirine whose electrophilicity was enhanced. Importance of this "proton transfer" strategy was successfully demonstrated by showing that a nonprotonated $2 \mathrm{H}$-azirine did not react with a corresponding nucleophile under the otherwise identical reaction condition. The reaction scope was very broad and tolerated various substituents 
on both nucleophiles and electrophiles, affording various enantio-enriched aziridines in 73-99\% yields with 2.4:1->20:1 diastereoselectivities and 91-98\% ee. Furthermore, the method worked on a gram-scale reaction with only $2 \mathrm{~mol} \%$ catalyst loading without any loss in stereoselectivities; albeit, it took $50 \mathrm{~h}\left(\mathrm{R}^{1}=\mathrm{Ph}, \mathrm{R}^{2}=\mathrm{Me}, \mathrm{Ar}=\mathrm{Ph}, 91 \%\right.$ yield, $>20: 1$ d.r., $97 \%$ ee).

$$
\mathrm{R}_{\substack{\mathrm{R}^{1} \\ \text { alkenyl, alkyl, }}}^{\mathrm{alk}}+\underset{\substack{1.5 \text { equiv } \\ \mathrm{Ar}=\text { aryl }}}{\mathrm{HO}_{2} \mathrm{Cr}} \mathrm{X}_{\mathrm{CN}}^{\mathrm{R}^{2}}
$$

$15(3 \mathrm{~mol} \%)$ CuOAc (3 $\mathrm{mol} \%)$

THF, -60 or $-20^{\circ} \mathrm{C}, 36$ or $12 \mathrm{~h}$

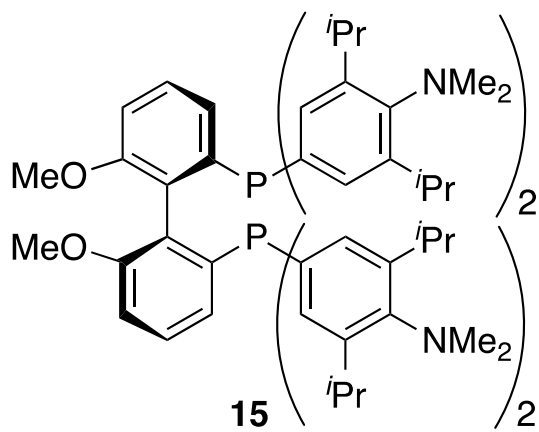<smiles>[R]C([Al])([Al])C1([R])CN1</smiles>

33 examples

$73-99 \%$ yields

d.r. $=2.4: 1->20: 1$

$91-98 \%$ ee

Scheme 14. Copper(I)-catalyzed asymmetric decarboxylative Mannich reaction of $2 \mathrm{H}$-azirines.

In 2020, Trost and coworker developed an asymmetric Mannich reaction of $2 H$-azirines with alkynyl cycloalkyl ketones (Scheme 15) [71]. The key to the success was to employ their bimetallic Zn-ProPhenol complex (16) that activated both nucleophiles and electrophiles within the same chiral pocket encompassing both Brønsted basic and Lewis acidic sites. The method efficiently provided the complex aziridines in $40-91 \%$ yields with $82-98 \%$ ee. The authors noted that possible intramolecular hydrogen bonding between the $\mathrm{N}-\mathrm{H}$ bond of the aziridine moiety and the carbonyl moiety within a product presumably resulted in a chiral center at the nitrogen atom, making the subsequent product characterizations very difficult. Therefore, a sequential N-H bond acetylation of the products was conducted.
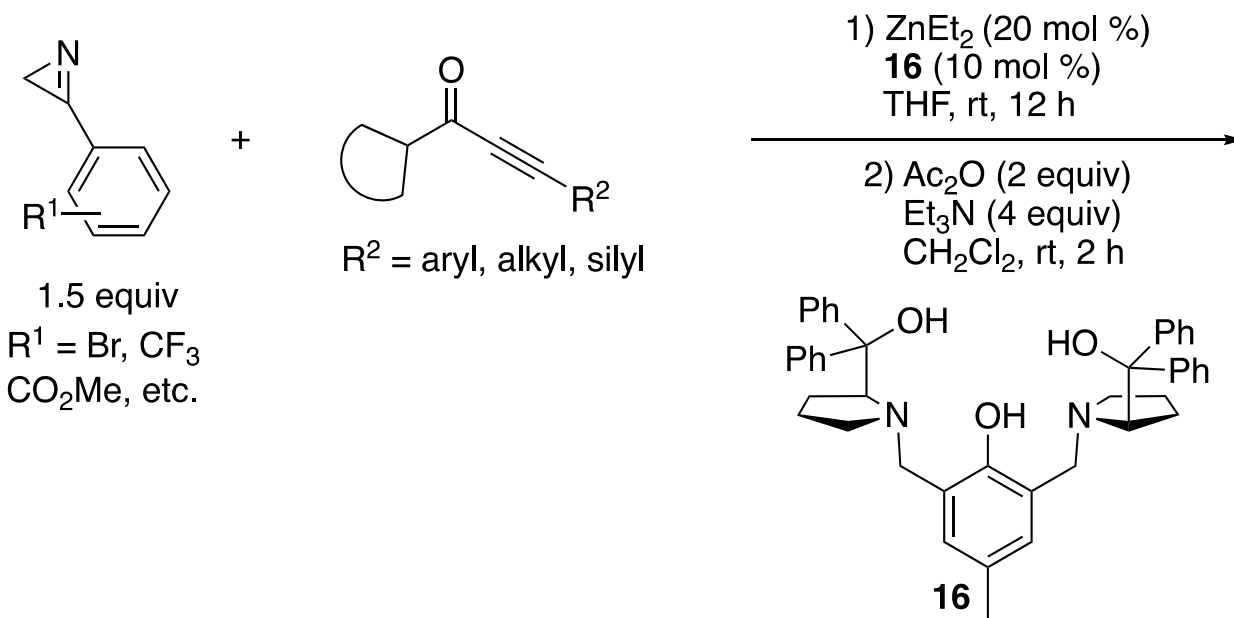

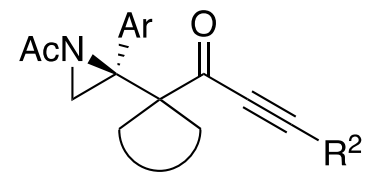

27 examples $40-91 \%$ yields $82-98 \%$ ee

Scheme 15. Zn-ProPhenol catalyzed asymmetric Mannich reaction of $2 H$-azirines with alkynyl cycloalkyl ketones.

\subsubsection{Silyl Enol Ethers}

In 2020, Zhang, Ma, and coworkers reported a chiral phosphoric acid-catalyzed Mukaiyama-Mannich reaction of endocyclic $\mathrm{N}$-acyl ketimines generated in situ from 3hydroxyisoindolin-1-ones (Scheme 16) [72]. They employed difluorinated silyl enol ethers as nucleophiles to prepare enantioenriched fluoroalkyl-functionalized isoindolones. During 
the screening of reaction conditions and chiral phosphoric acid catalysts, they found that (1) the use of hexafluoroisopropyl alcohol as additive was beneficial for both reactivity and enantioselectivity and (2) catalysts bearing trifluoromethylated chiral barriers $\left(\mathrm{Ar}^{2}\right)$ were superior to counterparts having no trifluoromethyl group. As such, they tested a nonfluorinated silyl enol ether $\left(\mathrm{F}=\mathrm{H}, \mathrm{Ar}^{1}=\mathrm{Ph}\right)$ under the optimized reaction conditions and found it unreactive. The scope of both ketimines and silyl enol ethers were broad, and the Mannich products were obtained in 55-97\% yields with $48-99 \%$ ee. It is noteworthy that their method tolerated a tautomerizable ketimine $\left(R^{2}=\mathrm{Me}\right)$, giving the corresponding product $\left(\mathrm{R}^{1}=\mathrm{H}, \mathrm{Ar}^{1}=\mathrm{Ph}\right)$ in $85 \%$ yield with $48 \%$ ee (see Scheme 11 for comparison). Furthermore, a gram-scale reaction was successfully demonstrated $\left(\mathrm{R}^{1}=\mathrm{H}, \mathrm{R}^{2}=\mathrm{Ar}^{1}=\mathrm{Ph}\right.$, $98 \%$ yield, and $96 \%$ ee).<smiles>[R7]C1(O)NC(=O)C2=C1C=C[R]C=C2</smiles>

$\mathrm{R}^{1}=\mathrm{Cl}, \mathrm{Br}$, OMe $\mathrm{R}^{2}=$ aryl, heteroaryl, Me<smiles>COC([Al])=C(F)F</smiles>

2 equiv $\mathrm{Ar}^{1}=$ aryl, heteroaryl
$17(5 \mathrm{~mol} \%)$ $\left(\mathrm{CF}_{3}\right)_{2} \mathrm{CHOH}$ (2 equiv)

toluene, $0{ }^{\circ} \mathrm{C}, 30-72 \mathrm{~h}$

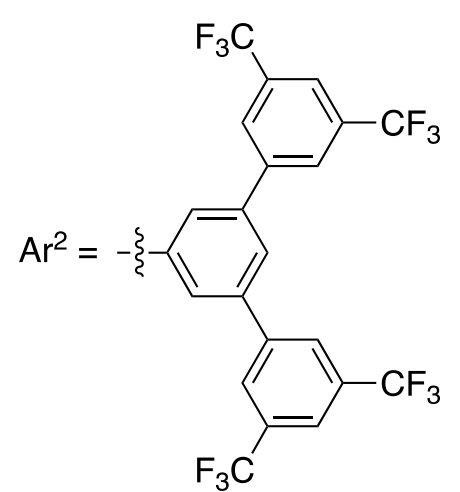<smiles></smiles>

29 examples $55-97 \%$ yields $48-99 \%$ ee<smiles>O=P(O)(O)Oc1c([Al])ccc2c1[C@]1(CCC2)CCc2cccc([Al])c21</smiles>

17

Scheme 16. Chiral phosphoric acid-catalyzed Mukaiyama-Mannich reaction of endocyclic $N$-acyl ketimines.

\subsection{Isatin-Derived Ketimines}

3-substituted-3-aminooxindoles are an important structural motif found in numerous natural products and biologically relevant molecules. The catalytic asymmetric Mannich reaction of isatin-derived ketimines provides direct access to enantio-enriched 3-substituted-3aminooxindoles. Furthermore, isatin-derived ketimines are relatively reactive electrophiles. As such, many catalytic asymmetric Mannich reactions of isatin-derived ketimines have been reported. In light of the excellent review articles that covered up to the end of 2017 [73-75], we discuss herein a few selected examples published after that period (for other selected examples, see: [76-84]).

\subsubsection{Direct Mannich}

In 2018, Morimoto, Ohshima, and coworkers reported a decarboxylative Mannich reaction of $\mathrm{N}$-unprotected isatin-derived ketimines, which directly afforded enantio-enriched chiral oxindoles bearing primary amines at their 3-postions (Scheme 17) [85]. The method that can accommodate substrates that have no protecting groups are more step- and atomeconomical than the counterparts that require them [86-88]. The method tolerated various ketoacids, affording the Mannich products in $69-99 \%$ yields with $79-96 \%$ ee. Their preliminary mechanistic study indicated that the addition of a ketoacid to a ketimine preceded the decarboxylation process with their catalytic system. 
<smiles>[R]C(=O)CC(=O)O</smiles>

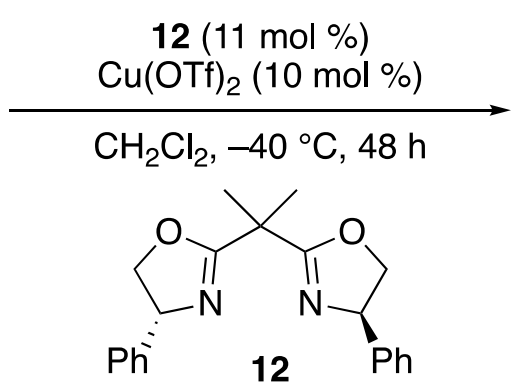

19 examples $69-99 \%$ yields $79-96 \%$ ee

Scheme 17. Copper-catalyzed Mannich reaction of $N$-unprotected isatin-derived ketimines.

In 2019, Wolf and coworkers developed a copper-catalyzed stereodivergent asymmetric Mannich reaction of isatin-derived ketimines and $\alpha$-fluoro- $\alpha$-arylnitriles (Scheme 18) [89]. A chiral cuprous keteniminate complex generated from $\alpha$-fluoro- $\alpha$-arylnitrile, a chiral copper catalyst, and BTMG was proposed as a nucleophile. The Segphos (18)-copper complex provided anti diastereomers in 81-99\% yields with 8.5:1->50:1 diastereoselectivities and 84-97\% ee. On the other hand, the Taniaphos (19) complex afforded syn diastereomers in $84-99 \%$ yields with 3:1-6.7:1 diastereoselectivities and 83-97\% ee. The switching of diastereoselectivities was successfully demonstrated by choosing a proper combination of the chiral ligand and the isatin $N$-protecting group (trityl or phenyl). Furthermore, a gram-scale reaction $\left(\mathrm{R}^{1}=\mathrm{H}, \mathrm{R}^{2}=\right.$ trityl, $\mathrm{Ar}=\mathrm{Ph}, 99 \%$ yield, $12.7: 1$ d.r., $90 \%$ ee) was successfully carried out without compromising yield and stereoselectivities.<smiles>[H][Y]1ccc2c(C(=O)OC(C)(C)C)c(=O)[nH]c2c1</smiles>

$\mathrm{R}^{1}=\mathrm{Me}, \mathrm{Et}, \mathrm{OMe}$ $\mathrm{R}^{2}=$ trityl or $\mathrm{Ph}$

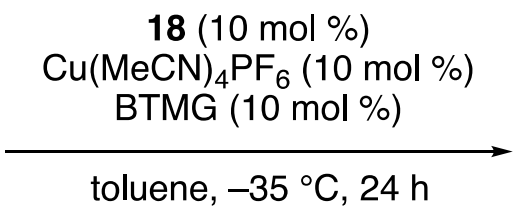<smiles>N#CC(F)(Br)C1(NC(=O)O)C=C2[R17]=CC=C2NC1=O</smiles>

1.1 equiv

$\mathrm{Ar}=\mathrm{Ph}, 3-\mathrm{MeO}-\mathrm{Ph}$ 3-Br-Ph, etc.<smiles>CN(C)C(=NC(C)(C)C)N(C)C#CBr</smiles><smiles>COc1ccc(P(c2ccc3c(c2)OCO3)c2ccc3c(c2-c2c(P(c4cc(Br)c(Br)c(Br)c4)c4cc(Br)c(C(C)(C)C)c(Br)c4)ccc4c2OCO4)OCO3)cc1Br</smiles>

anti $\mathrm{R}^{2}=$ trityl 18 examples $81-99 \%$ yields d.r. $=8.5: 1->50: 1$ $84-97 \%$ ee

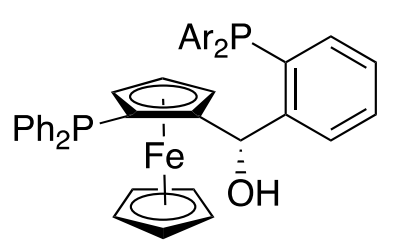<smiles>N#CC(F)(Br)C1(NC(=O)OCc2ccccc2)C(=O)Nc2cc[R][14cH]c21</smiles> 
In 2020, Liu, Feng and coworkers described several Lewis acid-catalyzed enantioselective transformations of $\beta, \gamma$-unsaturated 2-acyl imidazoles; the study of which included ketimines as electrophiles (Scheme 19) [90]. After the screening of the reaction conditions, the catalyst complex generated from $\mathrm{La}(\mathrm{OTf})_{3}$ and $(S)$-pipecolic acid-derived ligand was found to promote the Mannich reaction of isatin-derived ketimines and $\beta, \gamma$-unsaturated 2 -acyl imidazoles, delivering the desired $\beta$-amino 2 -acyl imidazoles as single regio- and diastereo-isomers in $75-99 \%$ yields and $88-91 \%$ ee. The pyrazolinone-derived ketimines were also demonstrated to be good substrates for their method (not shown).<smiles>CN1C(=O)C(=N[R6]([O-])([O-])OC(C)(C)C)c2cc[R17]cc21</smiles>

$\mathrm{R}^{1}=\mathrm{Me}, \mathrm{F}, \mathrm{Cl}, \mathrm{Br}$<smiles>Cn1ccnc1C(=O)C/C=C/Br</smiles>

$\mathrm{Ar}=\mathrm{Ph}, 2-$ naphthyl

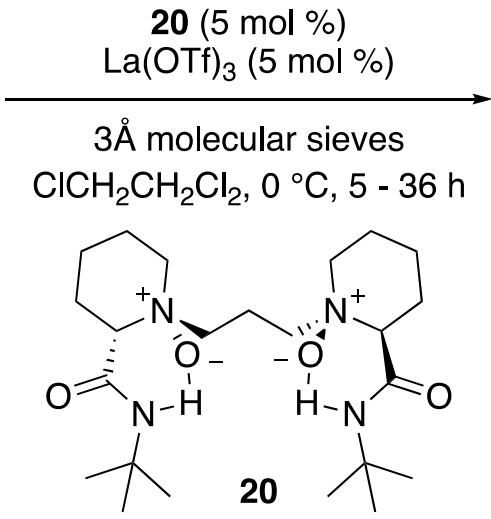

8 examples $75-99 \%$ yields $88-91 \%$ ee

Scheme 19. Chiral La-catalyzed Mannich reaction of isatin-derived ketimines with $\beta, \gamma$-unsaturated 2 -acyl imidazoles.

\subsubsection{Silyl Enol Ethers}

In 2019, Feng and coworkers reported a serendipitously discovered tandem $\alpha$-alkenyl addition/proton shift reaction of silyl enol ethers and ketimines catalyzed by chiral $N, N^{\prime}$ dioxide/Zn(II) complexes (Scheme 20) [91]. After the optimization of reaction conditions, dioxide 21 was found to be optimal for a series of isatin-derived ketimines (1), giving the products in $83-90 \%$ yields with $94-95 \%$ ee. A gram-scale reaction $\left(\mathrm{R}^{1}=\mathrm{H}\right)$ was successfully demonstrated without compromising yield and stereoselectivity ( $86 \%$ yield and 95\% ee). With respect to the scope of silyl enol ethers, dioxide 22 turned out best and provided the products in 21-90\% yields with $87-97 \%$ ee and 8:1->19:1 diastereoselectivities (for racemic $\alpha^{\prime}$-substituted cyclic silyl enol ethers that required $10 \mathrm{~mol} \%$ catalyst loadings). The pyrazolinone-derived ketimines were also demonstrated to be good substrates for the method (not shown). Their preliminary mechanistic study strongly supported that the Mukaiyama-Mannich addition intermediates got protonated by isopropanol (additive) before the subsequent silyl shift, giving the corresponding $\beta$-amino silyl enol ethers.

\subsection{Acyclic Ketimines Bearing Electron-Withdrawing Groups and/or Alkynes}

Ketimines substituted with esters, perfluorinated alkyl, or alkyne groups are relatively good electrophiles, and thus, enolates with a range of different nucleophilicities (i.e., different catalytic methods) were reported for their Mannich reactions. Nonetheless, some examples presented in this section demonstrate that seemingly subtle differences in the ketimine structures substantially affected chemical yields and stereoselectivities, highlighting the challenging nature of ketimine Mannich reactions. On the other hand, some ketimines presented herein were creatively designed so as to not only circumvent the inherent problems of unmodified ketimines but also to provide synthetically and medicinally important chiral building blocks. 
1)

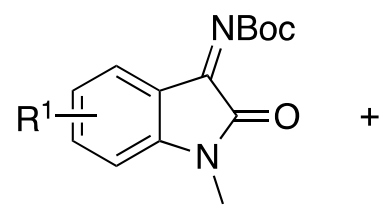

$\mathrm{R}^{1}=\mathrm{Me}, \mathrm{OMe}, \mathrm{F}, \mathrm{Br}, \mathrm{I}$

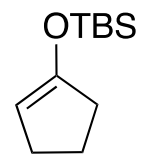

1.5 equiv
$21(5 \mathrm{~mol} \%)$

$\mathrm{Zn}(\mathrm{OTf})_{2}(5 \mathrm{~mol} \%)$

iPrOH (1.5 equiv)

$4 \AA ̊$ molecular sieves

$\mathrm{ClCH}_{2} \mathrm{CH}_{2} \mathrm{Cl}_{2}, 40{ }^{\circ} \mathrm{C}, 3-24 \mathrm{~h}$

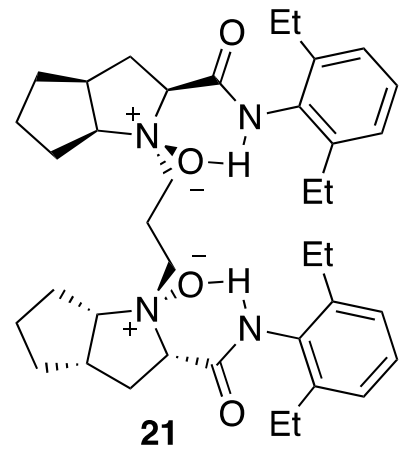

$22(2.5-5 \mathrm{~mol} \%)$

$\mathrm{Zn}(\mathrm{OTf})_{2}(2.5-5 \mathrm{~mol} \%)$ iPrOH (1.5 equiv)

$4 \AA ̊$ molecular sieves $\mathrm{ClCH}_{2} \mathrm{CH}_{2} \mathrm{Cl}_{2}, 40{ }^{\circ} \mathrm{C}, 6-96 \mathrm{~h}$

$$
\begin{aligned}
& 1.5 \text { equiv } \\
& \mathrm{n}=0-3 \\
& \mathrm{R}=\mathrm{Cl} \text {, alkyl }
\end{aligned}
$$<smiles></smiles>

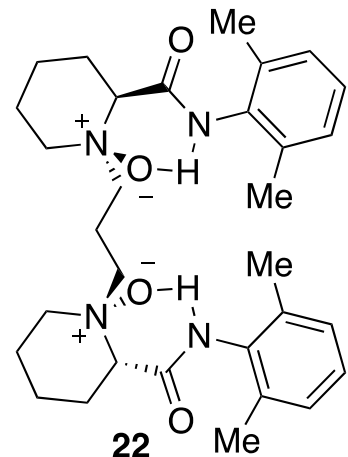

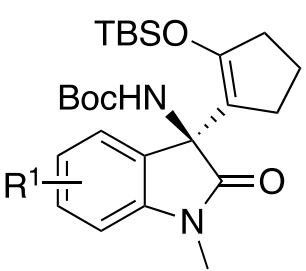

6 examples $83-90 \%$ yields $94-95 \%$ ee
2)<smiles>CN1C(=O)C(=NC(C)(C)C)c2ccccc21</smiles>

Scheme 20. Tandem $\alpha$-alkenyl addition/proton shift reaction of silyl enol ethers with ketimines.

Direct Mannich

In 2016, Terada and coworkers developed a novel asymmetric direct Mannich reaction of ketiminoesters with thionolactones using bis(guanidino)iminophosphorane $\mathbf{2 3}$ as a chiral organosuperbase catalyst (Scheme 21) [92]. Thionolactones were identified as suitable nucleophiles, while a corresponding lactone did not undergo the reaction. It was presumed that a lactone was not acidic enough to get enolized by the base catalyst. With respect to the electrophiles, the substituent on the benzoyl protecting group was found crucial for both chemical yield and diastereoselectivity. For example, a corresponding methoxy-substituted ketiminoester $\left(\mathrm{CF}_{3}=\mathrm{OMe}\right)$ provided the product in much lower yield and selectivity $\left(\mathrm{Ar}=p\right.$-tol: for $\mathrm{CF}_{3}, 93 \%$ yield, d.r. $=95: 5$; for $\mathrm{OMe}, 35 \%$ yield, d.r. $\left.=88: 12\right)$. Under the optimized conditions, the method provided the products with vicinal quaternary stereogenic centers in 56->99\% yields with 95:5-99:1 diastereoselectivities and 83-93\% ee. 
<smiles>CCOC(=O)C(=[Ga])N=C(O)c1ccc(C(F)(F)F)cc1</smiles><smiles>CCOC(=O)N[C@]([Al])(NC(=O)c1ccc(C(F)(F)F)cc1)C1COC(=S)[C@H]1Br</smiles>

9 examples $56->99 \%$ yields d.r. $=95: 5-99: 1$ $83-93 \%$ ee

23: $R^{2}=$ benzhydryl

Scheme 21. Chiral organosuperbase-catalyzed direct Mannich reaction of ketiminoesters.

As part of their longstanding interests in the soft Lewis acid/hard Brønsted base cooperative catalysis, in 2016 Kumagai, Shibasaki, and a coworker developed the direct catalytic asymmetric Mannich reaction of an $\alpha, \beta$-unsaturated $\gamma$-butyrolactam with ketiminoesters (Scheme 22) [93]. This method was found to give the $\alpha$-addition products (aza-Morita-Baylis-Hillman type products) through the regioselective $\alpha$-addition of the dienolate intermediate followed by isomerization of a double bond. This work represents the first $\alpha$-addition of $\alpha, \beta$-unsaturated $\gamma$-butyrolactams to ketimines under the asymmetric catalysis conditions. The interaction of the soft Lewis acidic copper catalyst and soft Lewis basic thiophosphinoyl protecting group of ketimines was suggested crucial for the success of this Mannich reaction, because a corresponding phosphinoyl protected ketiminoester did not react under the otherwise identical reaction conditions. These observations were consistent with their earlier works on the soft Lewis acid/hard Brønsted base cooperative catalysis (vide infra). The method accommodated 17 ketiminoesters and provided the $\beta$-amino carbonyl products in 55-99\% yields with 74-94\% ee. A gram-scale reaction was demonstrated without any loss in yield or ee ( $\mathrm{Ar}=\mathrm{Ph}, 99 \%$ yield, $91 \%$ ee).

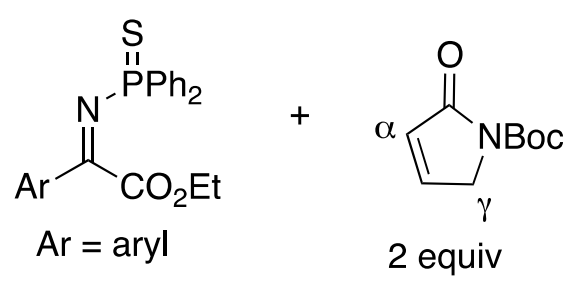

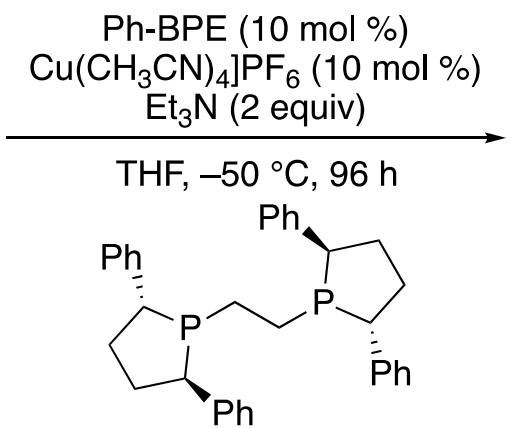

Ph-BPE

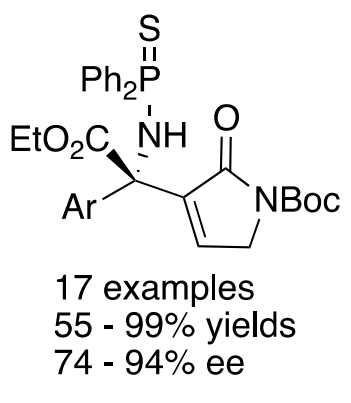

Scheme 22. Direct enantioselective Mannich reaction of $\alpha, \beta$-unsaturated $\gamma$-butyrolactam with ketiminoesters.

As part of their efforts in the development of the transformations employing $\mathrm{N}$ unprotected imines/ketimines, in 2017 Morimoto, Ohshima, and coworkers reported a direct enantioselective Mannich reaction with an $\mathrm{N}$-unprotected trifluoromethyl ketiminoester (Scheme 23) [94]. While unprotected $\mathrm{N}-\mathrm{H}$ ketimines generally have limited stabilities, they often mitigate problems associated with the $E / Z$ isomerism in the asymmetric catalysis reactions. Under the optimized conditions, their method tolerated malonates, cyclic $\beta$-keto-nitriles, esters, and oxindoles (conducted at $0{ }^{\circ} \mathrm{C}$ instead of $-20^{\circ} \mathrm{C}$ ), providing the corresponding products in $77-99 \%$ yields with $78-94 \%$ ee, $75-98 \%$ yields with 
17:1->20:1 diastereoselectivities and 77->99\% ee, and 91-99\% yields with 11:1->20:1 diastereoselectivities and $81-98 \%$ ee, respectively.

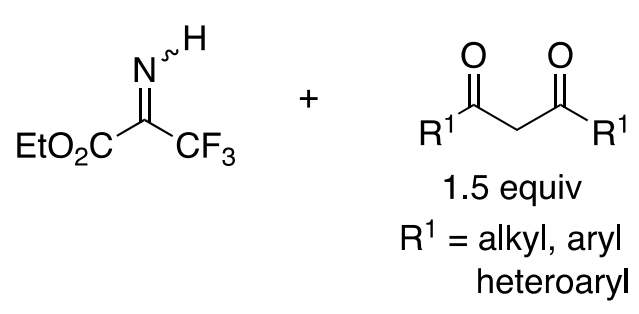<smiles>[X]c1ccc2c(c1)CC(C(C)(N)N)(C(N)(N)F)C2=O</smiles>

$\mathrm{R}^{2}=\mathrm{CN}, \mathrm{CO}_{2} \mathrm{Bzh}$

$\mathrm{X}^{1}=\mathrm{H}, \mathrm{F}, \mathrm{Br}, \mathrm{OMe}$

7 examples

$75-98 \%$ yields

d.r. $=17: 1->20: 1$

$77->99 \%$ ee

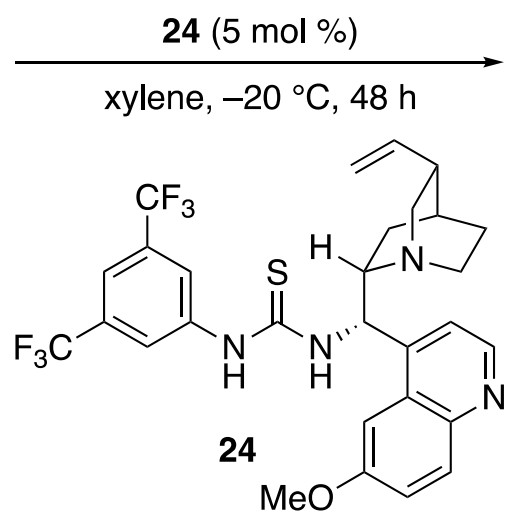<smiles>[R]C(=O)C(C(=O)CCC)C(N)(C(F)(F)F)C(F)(F)F</smiles>

12 examples $77-99 \%$ yields $78-94 \%$ ee

Scheme 23. Direct catalytic Mannich reaction with an $N$-unprotected trifluoromethyl ketiminoester.

In 2018, Trost and coworkers developed a Zn-ProPhenol catalyzed asymmetric Mannich reaction of $\alpha, \beta$ - and $\beta, \gamma$-butenolides with perfluoroalkyl alkynyl ketimines (Scheme 24) [95]. The method provided vinylogous products bearing two contiguous tetrasubstituted stereogenic centers. This represents the first successful use of ketimines in the ProPhenol Mannich process. They noted the salient features of perfluoroalkyl alkynyl ketimines; (1) a fluorinated group makes ketimines more electrophilic; (2) an alkyne is sterically much less demanding and its higher s character should further enhance the electrophilicity of ketimines; and (3) the increased steric differences between alkynyl and perfluoroalkyl groups would give ketimines in a single diastereomeric form, which is critical for high stereoselectivities. The reaction scope was very broad, providing the medicinally important (i.e., perfluoroalkyl groups) and synthetically versatile (i.e., alkynes) Mannich products in 35-92\% yields with 4:1->50:1 diastereoselectivities, 4:1->50:1 regioselectivities, and $54-99 \%$ ee.

Chiral amine catalysts derived from natural amino acids have proven highly effective for a wide range of enantioselective transformations. However, enantiomers of natural amino acids are not always readily available. As such, in 2019, Lan, Shao, and coworkers described their strategy to address this issue, which was "enantiodivergence" via minimal modification of a chiral amine catalyst (Scheme 25) [96]. They successfully demonstrated this strategy by applying their catalysts to the Mannich reaction of alkynyl ketiminoesters. By switching catalyst 26 and $\mathrm{MeCN}$ to 28 and dichloroethane, the corresponding enantiomers were obtained in almost the same yields and stereoselectivities. They also demonstrated that the same was true for a range of alkynyl trifluoromethyl-, isatin-derived-, and pyrazolinone-derived ketimines (not shown). 


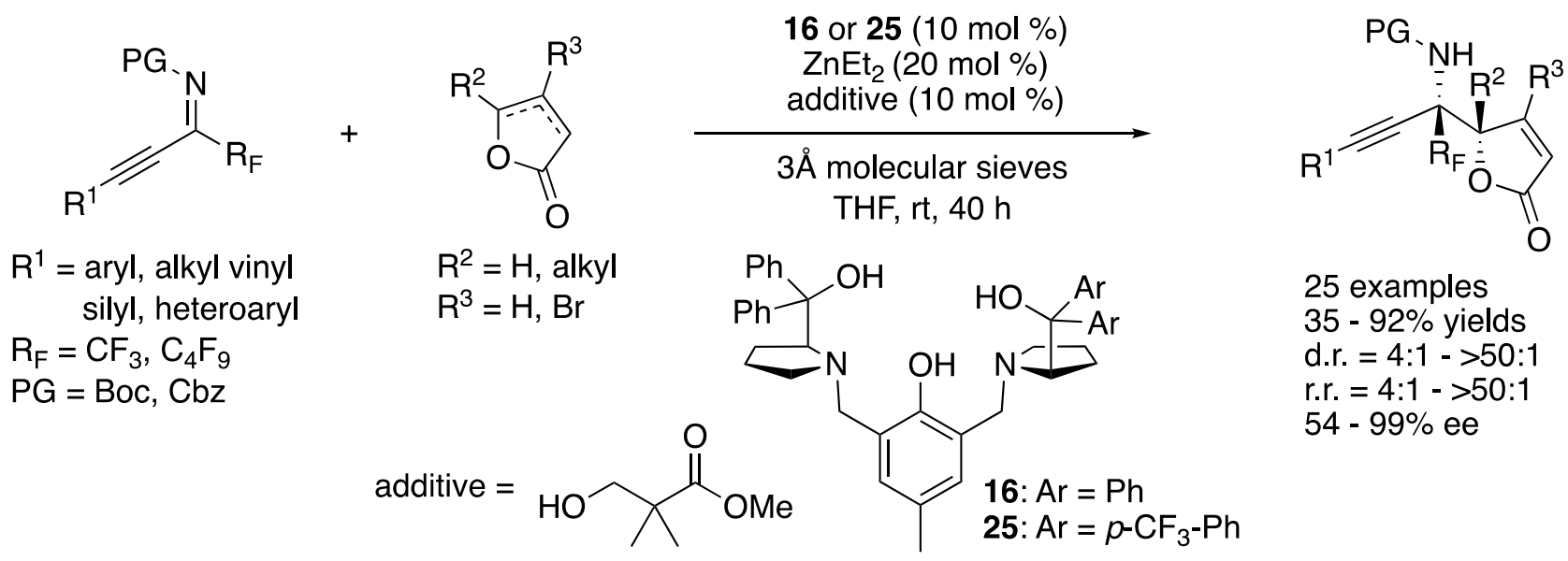

Scheme 24. Direct catalytic asymmetric vinylogous Mannich reaction of polyfluorinated alkynyl ketimines.
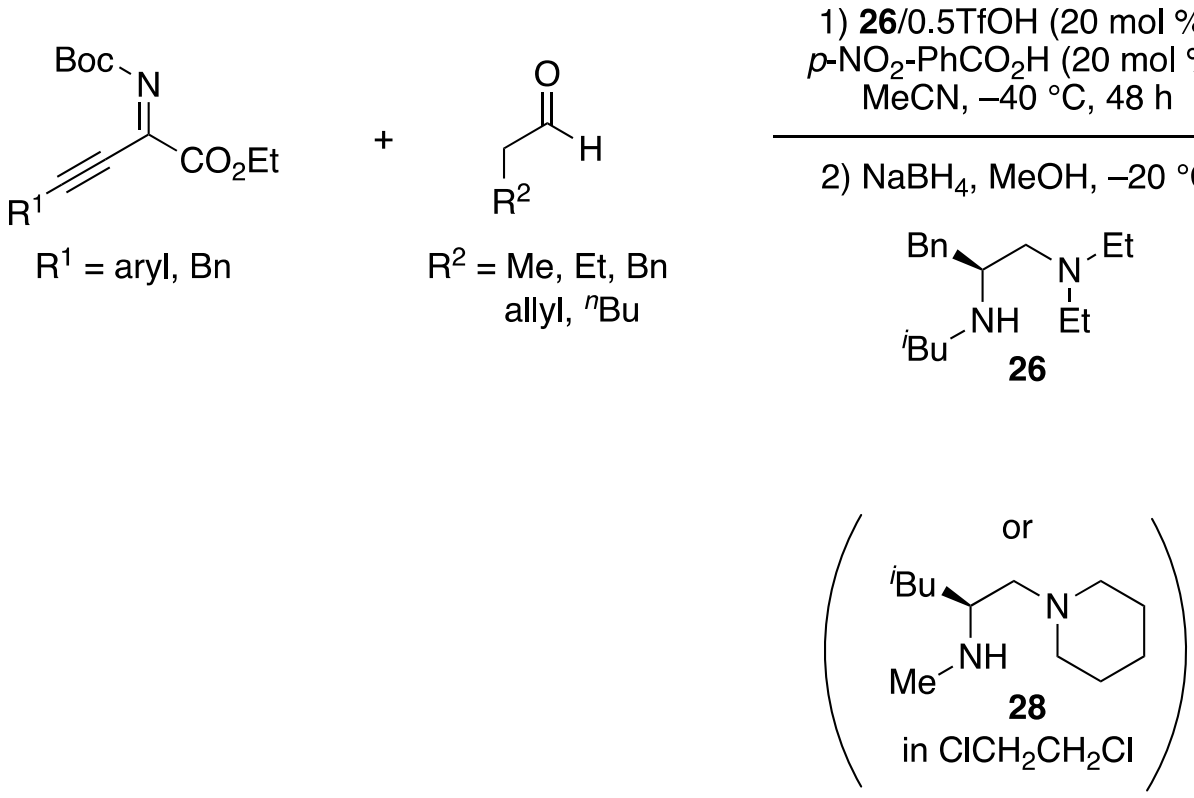

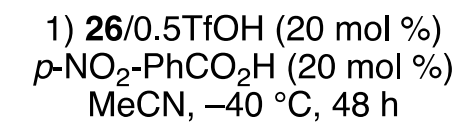

2) $\mathrm{NaBH}_{4}, \mathrm{MeOH},-20^{\circ} \mathrm{C}$<smiles>CCN(CC)CC(Br)NC(=O)c1ccccc1</smiles>

Scheme 25. Enantiodivergent Mannich reaction of alkynyl ketiminoesters catalyzed by chiral amines.

Ketimines bearing two structurally similar substituents exist as an inseparable $E / Z$ diastereomeric mixture and thus are rarely utilized in the asymmetric catalysis methods in contrast to ketimines that are available in a single diastereomeric form. Dialkyl ketimines are a prototypical example of such isomeric ketimine mixtures. They are also relatively easy to tautomerize to enamines (especially ones protected with Boc). In 2021, Kano, Maruoka, and coworkers reported a solution to this classical yet persisting problem, which is to utilize alkynyl alkyl ketimines as synthetic equivalents of dialkyl ketimines. The alkynyl groups in the reaction products can be readily reduced to the corresponding alkyl groups through simple hydrogenation. Furthermore, the steric size differences between alkynyl and alkyl groups are large enough to give alkynyl alkyl $\mathrm{N}$-protected ketimines in a single diastereomeric form, which in turn makes them easy to differentiate by a chiral catalyst. As discussed above, alkynyl-substituted ketimines are more reactive than the corresponding alkyl counterparts due to their electronegative sp hybridized carbon atoms and sterically small triple bonds. These advantageous properties of alkynyl alkyl ketimines certainly outweigh the cost of an extra hydrogenation step. Nonetheless, $\mathrm{N}$-Boc alkynyl alkyl ketimines are hardly accessible in a single diastereomeric form through dehydrative condensation reaction. Therefore, they developed the synthesis of $\mathrm{N}$-Boc- 
protected alkynyl alkyl ketimines ((1) and (2), Scheme 26) and then proceeded to evaluate them for chiral amine-catalyzed Mannich reactions (3) [97]. (Z)-Alkynyl alkyl ketimines underwent chiral amine-catalyzed Mannich reaction smoothly with aldehyde nucleophiles. Their method is stereodivergent; proline provided anti products in $42-77 \%$ yields with 8:1->20:1 diastereoselectivities and 96-99\% ee, and phenylcyclopropane-based amine 29 afforded syn counterparts in 60-84\% yields with 10:1->20:1 diastereoselectivities and 98-99\% ee. They successfully demonstrated the hydrogenation of the Mannich products, providing chiral amines bearing two structurally similar alkyl groups that are otherwise very difficult to prepare in an enantio-enriched form (not shown).

(1)

(2)<smiles>CC(C)(C)OC(=NC(=NC(=O)c1ccccc1)n1cnc2ccccc21)C(C)(C)C</smiles>

or<smiles>[R]C#CC([TlH])NC(=O)OC(C)(C)C</smiles>

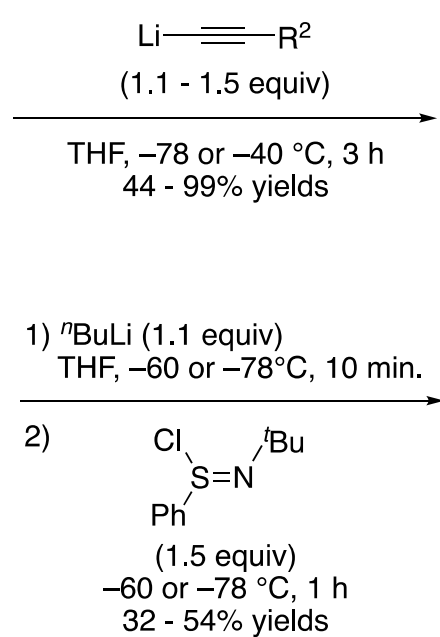

1) L-proline (20 mol \%) $\mathrm{CHCl}_{3}, \mathrm{rt}, 24 \mathrm{~h}$

or $(S, R)-29(10 \mathrm{~mol} \%)$<smiles>[R]C#C/C([R7])=N/[C@H](C)OC(C)(C)C</smiles>

$\mathrm{R}^{3}=\mathrm{Et}, \mathrm{Bu}, \mathrm{Bn}$ allyl, etc.<smiles>O=C(O)C1CCCN1</smiles>

L-proline
2) $\mathrm{NaBH}_{4}, \mathrm{MeOH}$<smiles>CCNc1cccc2c1CNCC1CC21</smiles>

$(S, R)-29$ $\mathrm{MeCN}, 5^{\circ} \mathrm{C}, 48 \mathrm{~h}$<smiles>[R7]C#C/C([Tl])=N\C(=O)OC</smiles>

(Z)-ketimines $\mathrm{R}^{1}=$ Pent, $\mathrm{Me},{ }^{\mathrm{i}} \mathrm{Bu}$ $\mathrm{R}^{2}=\mathrm{Me}, \mathrm{Bu}, \mathrm{Ph}$, Tips

Scheme 26. Chiral amine-catalyzed Mannich reactions of (Z)-alkynyl alkyl ketimines.

\section{Unmodified Ketimines in the Mannich Reaction}

Unless the ketimine activating groups are part of the desired products (e.g., $\mathrm{CF}_{3}$, isatin), they need to be transformed adequately or removed from the Mannich products, which adds steps that would not have been necessary otherwise (vide supra). Therefore, arguably, the development of the Mannich reaction with unmodified ketimines would be highly beneficial from the viewpoints of both atom and step economies [86-88].

\subsection{Silyl Ketene Acetals}

In 2007, Kanai, Shibasaki, and coworkers disclosed the first catalytic enantioselective Mannich reaction of unmodified ketimines using a preformed silyl ketene acetal and chiral copper complexes (Scheme 27) [98]. In these reactions, $N$-di(3,5-xylyl)phosphinoyl ketimines were employed, and a highly nucleophilic copper enolate was generated from a silyl ketene acetal and a chiral copper complex through transmetalation. They attempted 
(1)

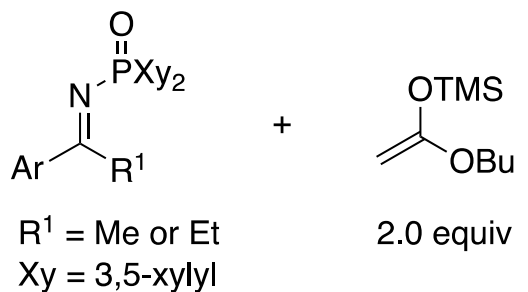<smiles>[R16]C(=O)N=[Y20]([H])=O</smiles>

4.0 equiv

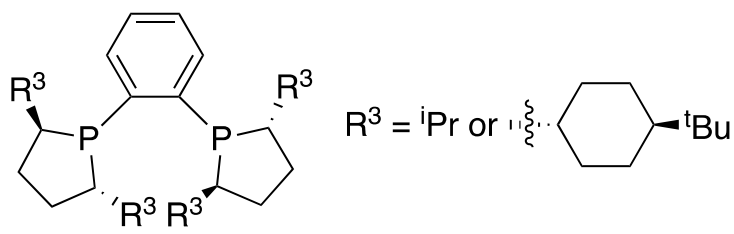

(2)
$\mathrm{R}^{2}=$ alkenyl, alkyl $\mathrm{Xy}=3,5-\mathrm{xy} \mid \mathrm{yl}$<smiles></smiles>

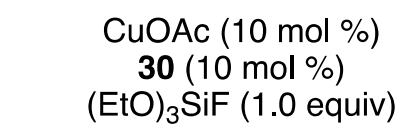

THF, $40^{\circ} \mathrm{C}, 20 \mathrm{~h}$<smiles>[Y20][PH](=O)N[C@@H]([Al])CC(=O)OCCC</smiles>

\section{7 examples} $61-92 \%$ yields $91-97 \%$ ee

to accelerate the presumable turnover-limiting catalyst regeneration step from the intermediate copper amide product by using an electrophilic silicon species, $(\mathrm{EtO})_{2} \mathrm{Si}(\mathrm{OAc})_{2}$ or $(\mathrm{EtO})_{3} \mathrm{SiF}$ as a trapping agent and successfully improved the yield. While optimal chiral ligands for aromatic and aliphatic ketimines turned out to be different, the method tolerated both classes of ketimines very well, giving the $\beta, \beta$-disubstituted amino acid equivalents in $61-92 \%$ yields with $91-97 \%$ ee and $45-99 \%$ yields with $58-81 \%$ ee, respectively. While they mentioned that the nucleophile scope was limited to acetate donors since $\alpha$-substituted enolates did not undergo the addition reaction, this work still remains as the state-of-the-art catalytic enantioselective Mannich reaction between unmodified ketimines and acetate donors.<smiles>[R]C(CC(=O)OCC)N[PH]([Y20])=O</smiles>

3 examples $45-99 \%$ yields $58-81 \%$ ee

30

Scheme 27. The first asymmetric catalytic Mannich reaction of unmodified ketimines.

In 2013, Nakamura and coworkers reported a diastereo- and enantio-selective vinylogous Mannich reaction of $\mathrm{N}$-diphenylphosphinoyl ketimines and 2-(trimethylsiloxy)furan catalyzed by a chiral copper(II) complex (Scheme 28) [99]. They proposed that a nucleophilic chiral copper dienolate complex generated from 2-(trimethylsiloxy)furan was an actual nucleophilic species. Cinchona alkaloid-derived amide 31 was found to be an optimal ligand, and its copper (II) complex tolerated both aromatic and aliphatic ketimines, giving the products 31-99\% yields with 88:12-99:1 diastereoselectivities and 91-97\% ee. 


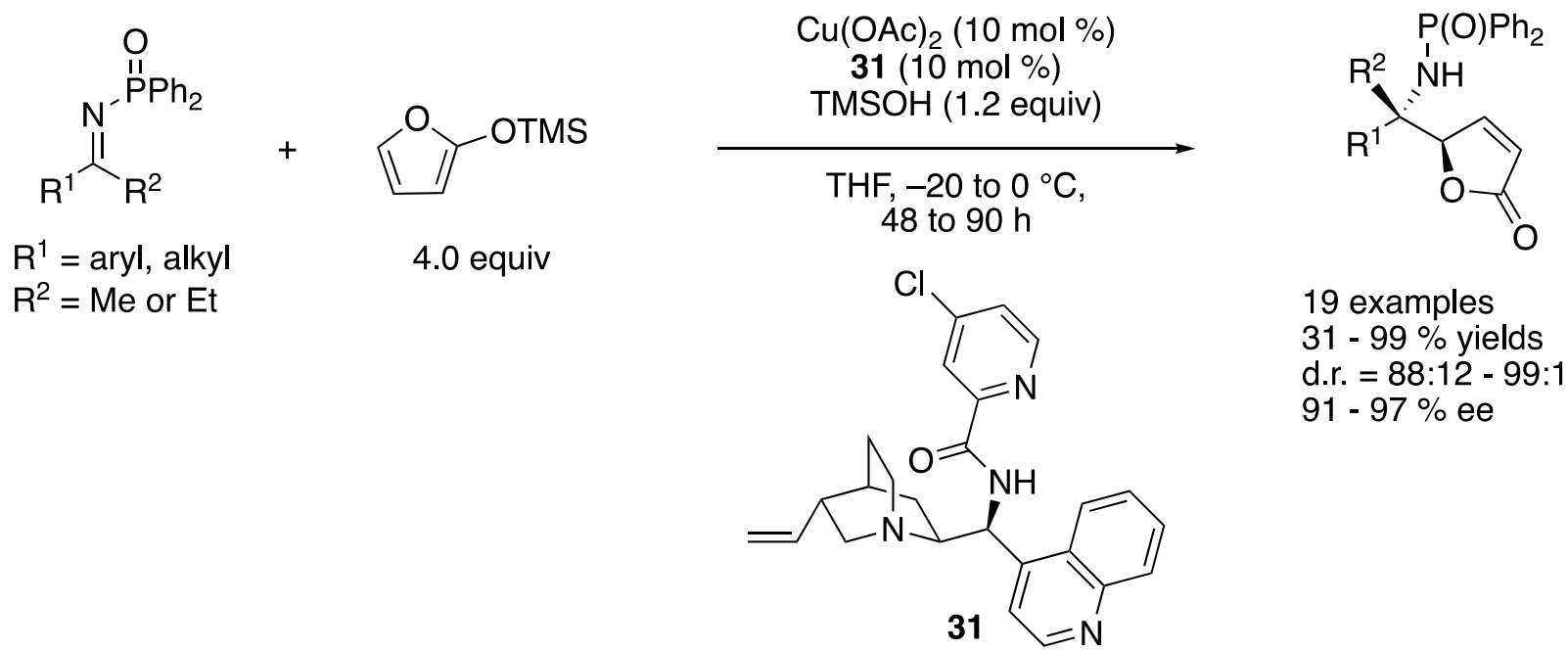

Scheme 28. Chiral copper(II) complex-catalyzed anti-selective vinylogous ketimine Mannich reaction.

\subsection{Reductive Mannich}

$\alpha, \beta, \beta$-trisubstituted $\left(\beta^{2,3,3}\right)$ amino acids are among the important building blocks for a wide variety of natural products, medicinally relevant molecules, and mimics of protein structural motifs. The ketimine Mannich reaction of $\alpha$-substituted enolates provides direct access to $\alpha, \beta, \beta$-trisubstituted amino acids from readily available carbonyl compounds. In 2008, Kanai, Shibasaki, and coworkers described their efforts to significantly expand their previous ketimine Mannich reaction (Scheme 27) that was limited to acetate nucleophiles (Scheme 29) [100]. Since they found that the copper enolate generation from a corresponding silicon enolate through transmetalation was the rate-limiting step for their method, they attempted to increase the concentration of active copper enolates by the conjugate addition of $\mathrm{Cu}$-based nucleophiles to $\alpha, \beta$-unsaturated esters. Their reductive enolate formation approach turned out to be fruitful and afforded the Mannich products in 47-95\% yields with 3:1-30:1 diastereoselectivities and 82-93\% enantiomeric excesses. This work is not only the first example of but also state of the art for the Mannich reaction between nonactivated ketimines and propionate nucleophiles.<smiles>[R]C=CC(=O)OCC</smiles>

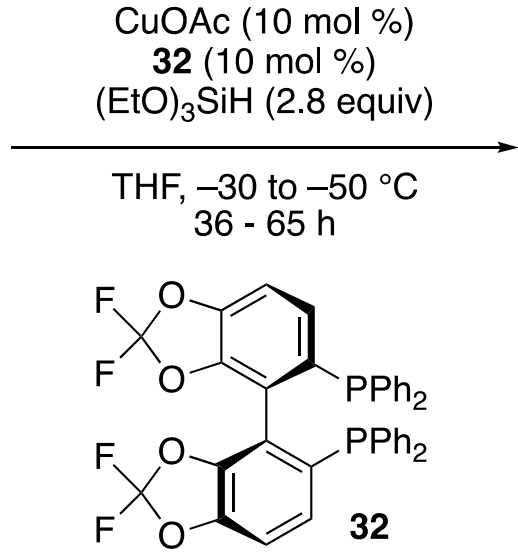

CuOAc $(10 \mathrm{~mol} \%)$

(EtO) ${ }_{3} \mathrm{SiH}(2.8$ equiv)<smiles>[R]CC(C(=O)OCC)C([R])NP(=O)=O</smiles>

syn:

7 examples

$47-95 \%$ yields

d.r. $=3: 1-30: 1$

$82-93 \%$ ee

Scheme 29. State-of-the-art enantioselective propionate ketimine Mannich reaction.

Reep and Takenaka developed a simple method to generate exceedingly reactive $\mathrm{O}$-trichlorosilyl- $\mathrm{N}-\mathrm{O}$-ketene acetals from corresponding acrylamides and $\mathrm{HSiCl}_{3}$ under the Lewis base catalysis conditions as an approach to the propionate ketimine Mannich reaction (Scheme 30) [101]. At the outset of their study, they found that the reported reductive method for $\alpha, \beta$-unsaturated ketones [102,103] quantitatively reduced dimethylacrylamide 
in the presence of benzaldehyde, but no aldol products formed, although they fully reproduced the reported reductive aldol reaction. Since the $\mathrm{D}_{2} \mathrm{O}$ quenching of the reaction did not incorporate the detectable amount of $\mathrm{D}$ atom in a resulting propionamide, they hypothesized that this hitherto unknown O-trichlorosilyl-N-O-ketene acetal got rapidly protonated by a small amount of $\mathrm{HCl}$ intrinsic to $\mathrm{HSiCl}_{3}$. After screening various proton scavengers, they found that activated $4 \AA$ molecular sieves (MS) were optimal. Their success could be attributed to the "sieve effect" since 3 and $5 \AA$ MS gave the similar results but not $10 \AA$ MS. These findings highlighted the exceedingly higher nucleophilicity of $\mathrm{O}$-trichlorosilyl- $\mathrm{N}$-O-ketene acetal than ketone-derived counterparts that underwent aldol reactions in the absence of proton scavengers. They focused on $\alpha$-mono-substituted $Z(O)$ $\mathrm{N}, \mathrm{O}$-ketene acetals, because the high nucleophilicity is presumably derived from their nitrogen lone-pairs that can donate electron density to the enol units. The corresponding $\alpha, \alpha$-disubstituted ketene acetals lose this electronic benefit due to the allylic strain that pushes their nitrogen lone-pairs out of conjugation with the enol functionality [104-106]. They tested the reductive method for an aliphatic ketone-derived benzoylhydrazone and found that the desired product formed in $96 \%$ yield with 11:1 diastereoselectivity and only $2 \%$ ee. Since their method provided an anti diastereomer, it could possibly be developed into a complementary method to Shibasaki's syn-selective propionate ketimine Mannich reaction (Scheme 29). The relative stereochemistry of the Mannich product was established by the X-ray analysis of the product crystal [107].

(1)<smiles>[R]N([R])C(=O)C=C</smiles>

$33(10 \mathrm{~mol} \%)$

$$
\mathrm{HSiCl}_{3} \text { (2 equiv) }
$$

$4 \AA \mathrm{MS}(1 \mathrm{~g} / \mathrm{mmol})$

$\mathrm{CH}_{2} \mathrm{Cl}_{2},-40^{\circ} \mathrm{C}, 6 \mathrm{~h}$<smiles>[R]N([R])/C(=C\C)[GeH2]Cl</smiles>

$99 \%$<smiles></smiles>

(2)<smiles>C/C(CCc1ccccc1)=N/N</smiles><smiles>C=CC(=O)N(C)C</smiles>

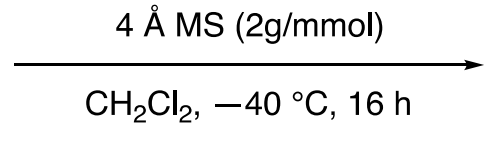

2 equiv<smiles>Cc1ccc(-c2cc3ccccc3c(-c3ccc(C)cc3)c3c4ccccc4cc(-c4ccc(C)cc4)[n+]([O-])c-3[n+]([O-])c2)cc1</smiles><smiles>CC(C(=O)N(C)C)[C@H](C)[C@@](C)(CCc1ccccc1)CNNC(=O)c1ccccc1</smiles>

relative stereochemistry

anti

$96 \%$ yield

d.r. $=11: 1$

$2 \%$ ee

Scheme 30. Anti-selective propionate ketimine Mannich reaction.

\subsection{Enamine}

In 2008, Tsogoeva and coworkers reported highly enantioselective self-coupling of enamides by using BINOL-derived phosphoric acids (Scheme 31) [108]. They took advantage of an equilibrium between ketimine and enamide in the presence of a chiral acid catalyst to utilize $\mathrm{N}$-acyl ketimines that are otherwise difficult to employ as electrophiles due to the tautomerization. The method provided the self-coupled products with $15-83 \%$ yields with $85->99 \%$ ee. They successfully demonstrated the utility of enantio-enriched self- 
coupled products by converting one example to a $\beta$-aminoketone without essential loss in its optical activity (2). This method is a viable alternative to the ketimine Mannich reaction.

(1)<smiles>C=C(Br)NC(=O)Br</smiles>

$\mathrm{R}^{1}=\mathrm{Me}, \mathrm{Et}, \mathrm{Pr}$
(2)<smiles>CC(=O)N/C(=C/C(C)(NC(C)=O)c1ccc(Cl)cc1)c1ccc(Cl)cc1</smiles><smiles>O=[N+]([O-])c1ccc(-c2cc3ccccc3c(OP(=O)(O)Oc3c(-c4ccc([N+](=O)[O-])cc4)cc4ccccc4c3-c3cc4ccccc4cc3[N+](=O)[O-])c2O)cc1</smiles>

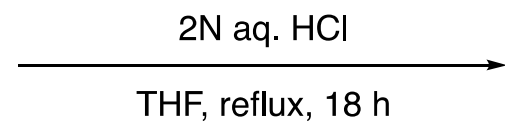<smiles>[R]C(=O)N/C(Br)=C/C(C)(Br)NC(=O)Br</smiles>

7 examples $15-83 \%$ yields $85->99 \%$ ee

Scheme 31. Asymmetric self-coupling of enamides by a BINOL-derived phosphoric acid.

\subsection{Direct Mannich}

In 2008, Kumagai, Shibasaki, and coworkers reported a direct catalytic asymmetric addition of allylic cyanides to ketimines (Scheme 32) [109]. They became interested in nitriles because these can be viewed as a masked carboxylic acid, are readily available, and could be small enough nucleophiles to overcome the severe steric demands of ketimines. Furthermore, they pointed out that allylic cyanides bear a relatively acidic $\alpha$-proton $\left(\mathrm{p} K_{\mathrm{a}}=21.1 \mathrm{in} \mathrm{DMSO}\right)$, and thus, they could be selectively deprotonated by a base catalyst in the presence of ketimines. They hypothesized that a soft Lewis acidic $\mathrm{Cu}-\mathrm{Ph}-\mathrm{BPE}$ complex selectively coordinated to a cyanide so as to allow a phenoxide to deprotonate it (i.e., soft enolization). To their delight, the reaction scope turned out broad, giving the products in $62-95 \%$ yields with $<2 / 98-12 / 88 E / Z$ ratios and $71-94 \%$ ee. They successfully demonstrated the utility of the products by converting one example to a densely functionalized $\beta^{\prime}$-amino $\alpha$, $\beta$-epoxyamide (2).

As a direct access to $\alpha, \beta$-diamino acid surrogates with vicinal tetrasubstituted stereocenters, Matsunaga, Shibasaki, and coworkers described the ketimine Mannich reaction with $\alpha$-methyl- $\alpha$-isothiocyanato ester in 2011 (Scheme 33) [110]. They began their study with catalysts made from $\mathrm{Bu}_{2} \mathrm{Mg}$ and BINAM-derived Schiff bases on the basis of their previous experiences with the aldol reaction of $\alpha$-methyl- $\alpha$-isothiocyanato ester and determined that the Schiff base shown in Scheme 33 was optimal with a model ketimine $\left(\mathrm{Ar}=4-\mathrm{BrC}_{6} \mathrm{H}_{6}\right)$. This chiral $\mathrm{Mg}$ catalyst afforded a syn diastereomer (36) as a major product $(87 \%$ yield, d.r. $=91: 9,84 \%$ ee). In order to improve stereoselectivities, they further investigated $\mathrm{Ca}\left(\mathrm{O}^{\mathrm{i}} \mathrm{Pr}\right)_{2}, \mathrm{Sr}\left(\mathrm{O}^{\mathrm{i}} \mathrm{Pr}\right)_{2}$, and $\mathrm{Ba}\left(\mathrm{O}^{\mathrm{i}} \mathrm{Pr}\right)_{2}$ with the same Schiff base. To their surprise, $\mathrm{Sr}\left(\mathrm{O}^{\mathrm{i} P r}\right)_{2}$ led to an unexpected reversal of the diastereoselectivity, providing an anti-isomer (37) as a major product $\left(\mathrm{Ar}=4-\mathrm{BrC}_{6} \mathrm{H}_{6}, 86 \%\right.$ yield, d.r. $=94: 6$, ee $\left.=92 \%\right)$ while 
the other two metals gave only trace amounts of the products. The reversal of the diastereoselection resulted from the opposite ketimine facial selectivities by the $\mathrm{Mg}$ and $\mathrm{Sr}$ catalysts. The ${ }^{1} \mathrm{H}$ NMR spectra of both catalysts were found to be complicated, which implicated a possibility of the oligomeric structures of theses catalysts. As such, the elucidation of the precise structures of the catalysts proved very challenging. Nonetheless, the $\mathrm{Mg}$ provided syn products in 70-99\% yields with 90:10-93:7 diastereoselectivities and 80-95\% ee, and the Sr catalyst gave anti products in 45-99\% yields with 83:17-96:4 diastereoselectivities and $87-97 \%$ ee. To demonstrate the synthetic utility of the products, an anti product $\left(\mathrm{Ar}=4-\mathrm{MeC}_{6} \mathrm{H}_{4}\right)$ was converted to a corresponding imidazoline and 2-phenyl-imidazoline (not shown).

(1)<smiles>[R]C([R])=N[R](=O)c1ccccc1</smiles>

$\left[\mathrm{Cu}\left(\mathrm{CH}_{3} \mathrm{CN}\right)_{4}\right] \mathrm{ClO}_{4}$ $(R, R)$-Ph-BPE

$\mathrm{Li}\left(\mathrm{OC}_{6} \mathrm{H}_{4}-p-\mathrm{OPh}\right)$ (10 mol \% each)

$\overrightarrow{\mathrm{CH}_{2} \mathrm{Cl}_{2} / \mathrm{THF}(2 / 1),-20^{\circ} \mathrm{C}, 40 \mathrm{~h}}$<smiles>c1ccc(C2CC[C@H](c3ccccc3)P2CCP2[C@H](c3ccccc3)CC[C@@H]2c2ccccc2)cc1</smiles>

$(R, R)$-Ph-BPE<smiles>[R]C/C=C(/C#N)C([R7])([R])NPOC</smiles>

12 examples 62 - $95 \%$ yields $E / Z=<2 / 98-12 / 88$ $71-94 \%$ ee
(2)<smiles>C/C=C(\C#N)[C@](C)(NC(=O)OCc1ccccc1)c1ccccc1</smiles><smiles>CC[C@H](C(N)=O)[C@@](C)(NP[OH+]c1ccccc1)c1ccccc1</smiles>

$91 \%$ ee

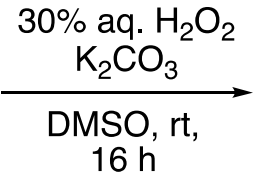

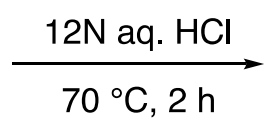<smiles>CCC(C(N)=O)C(C)(c1ccccc1)C(C)([Si])[Cl+]</smiles>

$76 \%$ yield (2 steps)

Scheme 32. Direct catalytic asymmetric addition of allylic cyanide to ketimines.<smiles>COC(=O)C([14CH3])[13CH2][13CH3]</smiles>

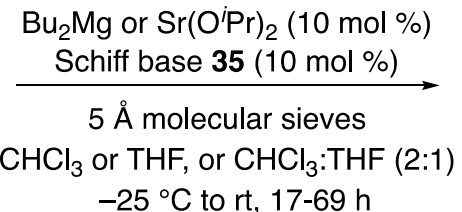<smiles>COc1cc(C=Nc2ccc3ccccc3c2-c2cccc3ccccc23)c(C=Nc2cccc3ccccc23)c(O)c1OC</smiles><smiles>COC(=O)[C@]1(C)NC(=S)N(C(C)C)C1(C)C</smiles>

syn-36:

8 examples

$70-99 \%$ yields

d.r. $=90: 10-93: 7$

$80-95 \%$ ee or<smiles>COC(=O)N1C(=S)N([PH](=O)Pc2ccccc2)C([Al])C1C</smiles>

anti-37:

12 examples $45-99 \%$ yields d.r. $=83: 17-96: 4$ $87-97 \%$ ee

Scheme 33. Stereodivergent direct catalytic asymmetric Mannich reaction. 
In 2013, Kumagai, Shibasaki, and coworkers reported a direct catalytic asymmetric vinylogous ketimine Mannich reaction of $\gamma$-butenolides (Scheme 34) [111]. For the development of direct catalytic asymmetric carbon-carbon bond-forming transformations under proton-transfer conditions, $\gamma$-butenolides have attracted much attention as useful pronucleophiles due to their relatively acidic protons that facilitate the generation of the corresponding dienolates and the high frequency of a $\gamma$-butenolide motif present in natural products and biologically relevant compounds. It is notable that prior to their contribution, $\gamma$-butenolides had not been employed in direct catalytic asymmetric vinylogous Mannich reactions with ketimines. On the basis of their continuing interests in the soft Lewis acid/hard Brønsted base cooperative catalysis (vide supra), they hypothesized that a soft Lewis acid would activate an $N$-(diphenylthiophosphinoyl)ketimine, while a hard Brønsted base would generate a dienolate from a $\gamma$-butenolide via deprotonation. They successfully demonstrated the importance of soft Lewis acid-soft Lewis base interaction (i.e., $\mathrm{Cu} \cdots \mathrm{S}$ interaction) by confirming that a $N$-phosphinoyl ketimine $\left(\mathrm{R}^{1}=\mathrm{Ph}, \mathrm{R}^{2}=\mathrm{Me}\right)$ barely reacted under the optimized reaction conditions. The reaction scope was broad and included two alkyl methyl ketimines and two methyl substituted $\gamma$-butenolides, giving the products in 52-92\% yields with $>20: 1$ diastereoselectivity and $97-99 \%$ ee.

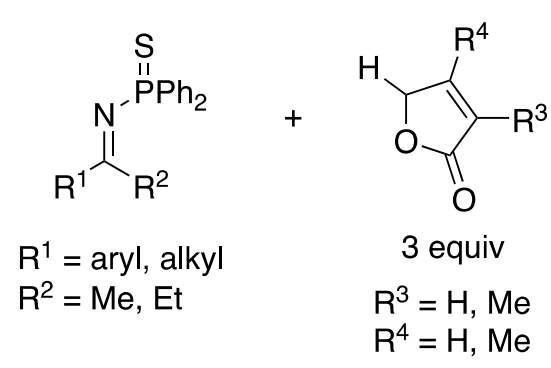

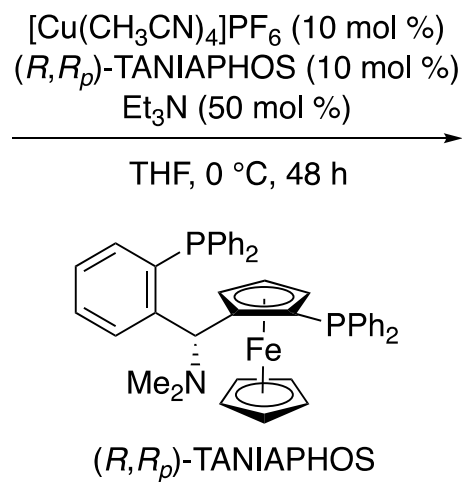

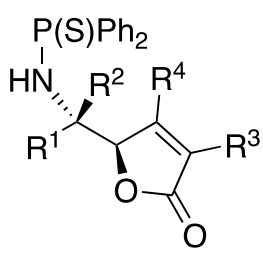

14 examples

$52-92 \%$ yields

d.r. $=>20: 1$

$97-99 \%$ ee

Scheme 34. Direct catalytic asymmetric vinylogous ketimine Mannich reaction of $\gamma$-butenolides.

In 2014, the groups of Dixon and Nakamura independently reported direct asymmetric Mannich reactions of isocyanoacetates and ketimines (Scheme 35) [112,113]. Despite the importance of $\alpha, \beta$-diamino acid building blocks in chemical synthesis of biologically relevant molecules, catalytic enantioselective addition of isocyanoacetates to ketimines were not reported before their contributions.

Dixon and a coworker found that when a combination of cinchona-derived aminophosphine precatalyst 38 and silver oxide was employed as a binary catalyst system, anticonfigured imidazoline products (39) were obtained in 70-98\% yields with 73:27-99:1 diastereoselectivities and 90-99\% ee (Scheme 35, (1)). It is notable that their method worked very well with the 1:1 ratio of ketimine and isocyanoacetate, indicating a high performance of their catalyst system. In general, excess of either electrophile or nucleophile is necessary for challenging asymmetric catalytic transformations such as the ketimine Mannich reaction. In 2016, they further developed this method to include $\alpha$-substituted isocyanoacetates whose reaction scope was broad and included various aryl, heteroaryl, and alkyl methyl ketimines (not shown) [114]. Hydrolysis of these imidazoline products afforded access to fully substituted $\alpha, \beta$-diamino acids in an enantio-enriched form.

Nakamura and coworkers reported that a complex made from alkaloid 40 and $\mathrm{Cu}(\mathrm{OTf})_{2}$ efficiently catalyzed the Mannich reaction of isocyanoacetate in the presence of $\mathrm{Cs}_{2} \mathrm{CO}_{3}$ (Scheme 35, (2)). Their method provided complementary syn-configured imidazoline products (41) in 45-78\% yields with 73:27-99:1 diastereoselectivities and 91-99\% ee. The corresponding 1-indanone-derived ketimine (i.e., a cyclic substrate) was also a good substrate for their method, affording the product in $44 \%$ yield with $91: 9$ diastereoselectivity and $98 \%$ ee. Notably, this catalyst system was found to work for the aliphatic ketimines 
(not shown). Two alkyl methyl ketimines $\left(\mathrm{Ar}=\mathrm{PhCH}_{2} \mathrm{CH}_{2}\right.$ and ${ }^{i} \mathrm{Bu}$ in (2)) gave anti diastereomers as major products (anti:syn $=72: 28$ and 60:40, 54 and $78 \%$ yields, 72 and $89 \%$ ee, respectively). In 2016, they also disclosed their investigation of the ketimine Mannich reaction of $\alpha$-substituted isocyanoacetates (not shown) [115]. A catalytic complex made from an alkaloid analogous to $\mathbf{4 0}$ and $\mathrm{NiCl}_{2}$ was found to be optimal for this reaction in which the substrate scope was broad. The enantioselective synthesis of imidazolines with vicinal tetrasubstituted stereocenters was achieved by this new chiral Ni complex.

(1) Dixon
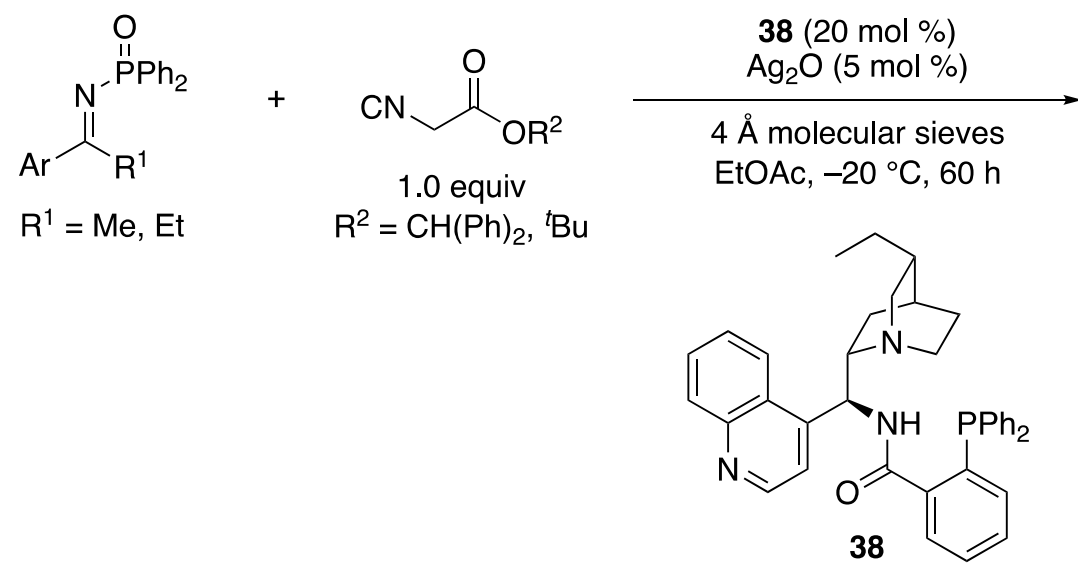

(2) Nakamura

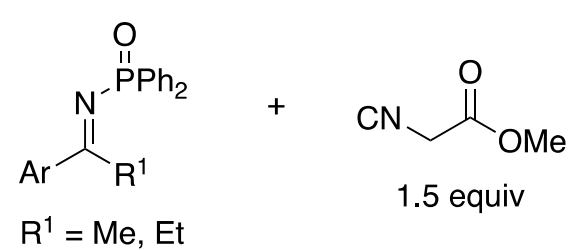

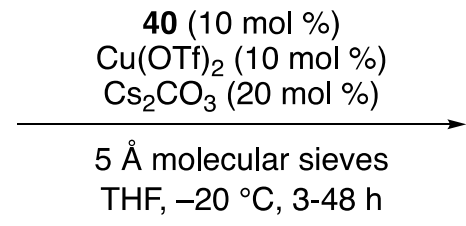<smiles>C=CC1CN2CCC1C2[C@H](NC(=O)c1cc(C(F)(F)F)ccn1)c1ccnc2ccccc12</smiles><smiles></smiles>

anti-39:

19 examples

$70-98 \%$ yields

d.r. $=73: 27-99: 1$

$90-99 \%$ ee

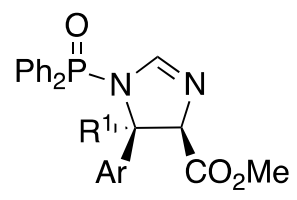

syn-41:

17 examples

$45-78 \%$ yields

d.r. $=73: 27-99: 1$

$91-99 \%$ ee

Scheme 35. Direct asymmetric Mannich reactions of isocyanoacetates and ketimines.

As part of their continuing interests in nitrile-based pronucleophiles and the soft Lewis acid/hard Brønsted base cooperative catalysis (vide supra), Kumagai, Shibasaki, and coworkers developed a direct catalytic asymmetric Mannich reaction of $\mathrm{N}$-(9-fluorenylidene)$\alpha$-aminoacetonitrile and $N$-(diphenylthiophosphinoyl)ketimines (Scheme 36) [116]. The method provided vicinal diamines bearing tetra- and tri-substituted contiguous stereogenic centers in 61-99\% yields with 77:23-95:5 diastereoselectivities and 83-95\% ee. It is notable that their method was highly enantioselective for aliphatic ketimines where the structural difference of the two groups flanking a $\mathrm{C}=\mathrm{N}$ bond was relatively small. Also worthy of mention is that only $3 \mathrm{~mol} \%$ catalyst loading was enough, and it worked on a gram-scale reaction without any detrimental effect $\left(\mathrm{R}^{1}=\mathrm{CH}_{2} \mathrm{CH}_{2} \mathrm{Ph}, \mathrm{R}^{2}=\mathrm{Me}, 48 \mathrm{~h}\right.$, $95 \%$ yield, d.r. $=91: 9,93 \%$ ee). Strangely enough, however, acetophenone-derived $N$ - 
(diphenylthiophosphinoyl)ketimine provided only trace amounts of the product under the optimized reaction conditions. They conducted a preliminary mechanistic study and found that the analogous $\mathrm{N}$-diphenylphosphinoyl ketimine $\left(\mathrm{R}^{1}=\mathrm{CH}_{2} \mathrm{CH}_{2} \mathrm{Ph}, \mathrm{R}^{2}=\mathrm{Me}\right)$ resulted in much lower conversion and stereoselectivity under the reaction conditions, and this catalytic system exhibited higher performance for differentiating the prochiral face of ketimines rather than that of $\alpha$-cyano carbanions. As such, the result suggested that the specific activation of the thiophosphinoyl group by a soft-Lewis acidic $\mathrm{Cu}(\mathrm{I})$ complex was crucial for the formation of a carbon-carbon bond and efficient stereochemical discrimination.<smiles>[R7]C([R7])=N[Pb]([18OH])=S</smiles>

1.1 equiv

$\mathrm{R}^{1}=$ alkyl

$\mathrm{R}^{2}=\mathrm{Me}, \mathrm{Et}$<smiles>CC(C)=[Te]=C1c2ccccc2-c2ccccc21</smiles>

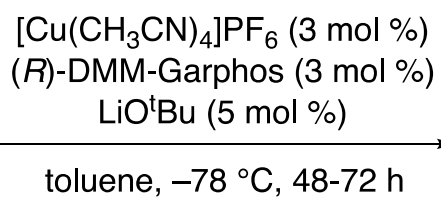

toluene, $-78^{\circ} \mathrm{C}, 48-72 \mathrm{~h}$<smiles>COc1cc(OC)c(-c2c(OC)cc(OC)cc2P(c2ccc(C)c(OC)c2)c2cc(C)c(OC)c(OC)c2)c(OC)c1</smiles>

(R)-DMM-Garphos<smiles>[R]C(N[PbH])C([R7])C(C#N)N=[Pt]</smiles>

12 examples

$61-99 \%$ yields

d.r. $=77: 23-95: 5$

$83-95 \%$ ee

Scheme 36. Direct catalytic asymmetric addition of $N$-alkylidene- $\alpha$-aminoacetonitrile to aliphatic ketimines.

In 2015, Nakamura and coworkers reported that a complex made from alkaloid 42 and $\mathrm{Zn}(\mathrm{OTf})_{2}$ efficiently catalyzed the ketimine Mannich reaction of a $\gamma$-butenolide (Scheme 37) [117]. The ketimine scope was broad and included aryl, heteroaryl, and alkyl methyl ketimines as well as 1-indanone-derived ketimine. The products were obtained in 79-99\% yields with 85:15-99:1 diastereoselectivities and 90:10-94:6 er. It is noteworthy that the pseudoenantiomeric catalyst gave very similar reactivity and selectivity for three ketimines $\left(\mathrm{R}^{1}=4-\mathrm{MeOC}_{6} \mathrm{H}_{4}, 4-\mathrm{FC}_{6} \mathrm{H}_{4}\right.$ and $\mathrm{EtOCOCH}{ }_{2} \mathrm{CH}_{2}$, in 81-84\% yields with 93:7-96:4 d.r. and 10:90-8:92 er) in this method, which is not always the case for cinchona-derived catalysts.
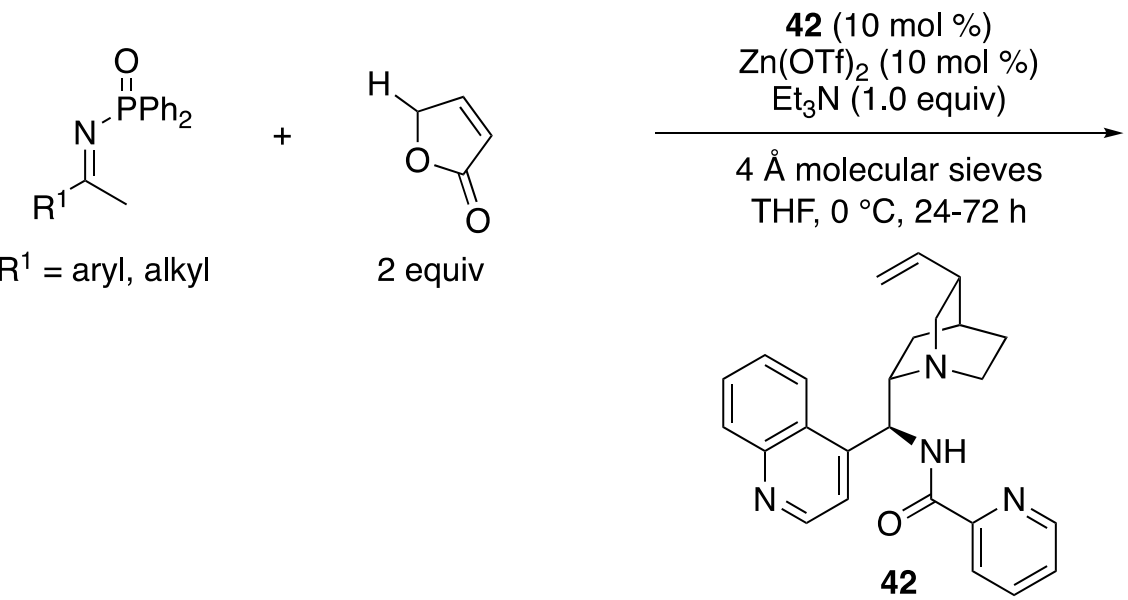

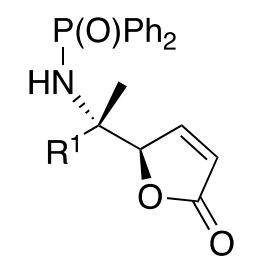

13 examples $79-99 \%$ yields d.r. $=85: 15-99: 1$ 90:10 - 94:6 er

Scheme 37. Direct enantioselective vinylogous Mannich reaction of ketimines with a $\gamma$-butenolide. 


\section{Activated and/or Cyclic Ketimines in the Allylation Reaction}

The addition of allylic organometallic reagents to carbonyl and imine compounds represents an important process in the chemical synthesis (selected reviews; [118-121]). When ketimines are employed as electrophiles, chiral homoallylic $\alpha$-tertiary amines are obtained. In light of a double bond in the products that can be viewed as a masked carbonyl, the allylation of the ketimines is analogous to the ketimine Mannich reaction.

\subsection{Endocyclic Ketimines}

\subsubsection{Allyl Rhodium Species}

In 2012, Lam and coworkers reported the first enantioselective rhodium-catalyzed addition of allylboron reagents to endocyclic ketimines (Scheme 38) [122]. Using only $1.5 \mathrm{~mol} \%$ of the catalyst complex, 1,2,5-thiadiazolidine-1,1-dioxides (43) underwent the reaction with various allyl-, crotyl- and prenyl-trifluoroborates, affording the corresponding products in 61-89\% yields with 17:1->19:1 diastereoselectivities and $95-99 \%$ ee, as did a cyclic sulfamidate imine (45) with allyltrifluoroborate, which provided a corresponding homoallylamine in $83 \%$ yield with $93 \%$ ee. In subsequent years, they expanded the substrate scope of the method, which included endocyclic $N$-sulfonyl ketimines bearing $\mathrm{CF}_{3}$ and $n$-butyl groups at the imine carbon atom as well as various potassium allyltrifluoroborates (not shown) [123,124].

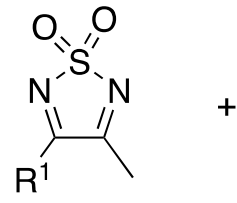

43: $\mathrm{R}^{1}=\mathrm{Me}, \mathrm{Ph}$<smiles>CC1=NS(=O)(=O)O[C@@H]1S</smiles><smiles>[R]C([R])=CC[B-]</smiles>

\section{5 equiv}

$\mathrm{R}^{2}=\mathrm{H}, \mathrm{Me},{ }^{n} \mathrm{Pr}$ $\mathrm{R}^{3}=\mathrm{H}, \mathrm{Me}$
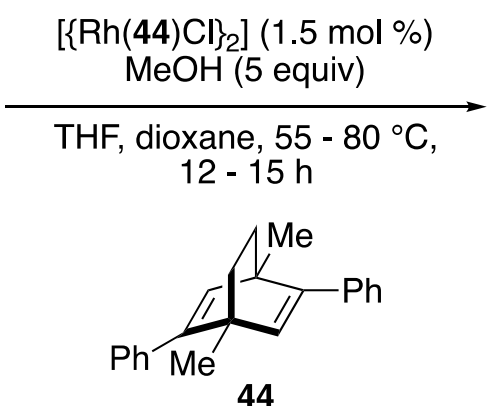

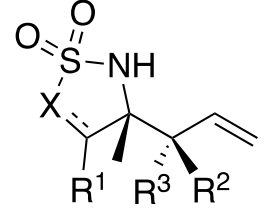

$$
\begin{aligned}
& X=N \\
& R^{1}=\text { Me or } P h \\
& 6 \text { examples } \\
& 61-89 \% \text { yields } \\
& \text { d.r. }=17: 1->19: 1 \\
& 95-99 \% \text { ee } \\
& X=O, \\
& R^{1}=R^{2}=R^{3}=H \\
& 83 \% \text { yield } \\
& 93 \% \text { ee }
\end{aligned}
$$

Scheme 38. Enantioselective rhodium-catalyzed allylation of endocyclic ketimines.

\subsubsection{Allyl Cobalt Species}

In 2018, Yang, Zhang, and coworkers described that the same classes of electrophiles and nucleophiles that were previously studied with chiral rhodium complexes by Lam and coworkers (vide supra) underwent the allylation reaction catalyzed by chiral complexes generated from more cost-effective $\mathrm{Co}\left(\mathrm{ClO}_{4}\right) \cdot 6 \mathrm{H}_{2} \mathrm{O}$ and $\mathrm{BOX}$ ligands. The method afforded the enantio-enriched homoallylamines in $78-98 \%$ yields with $3: 1$ diastereoselectivity and 53-99\% ee (Scheme 39) [125].

\subsection{Isatin-Derived and Analogous Cyclic Ketimines \\ 4.2.1. Allyl Palladium Species}

Ketimines derived from isatins have attracted much attention as electrophiles because they provide chiral 3-substituted 3-amino-2-oxindoles that are a structural motif found in biologically relevant compounds and natural products, and they are relatively reactive electrophiles, as discussed above. However, asymmetric catalytic allylation of isatin-derived ketimines had not been reported prior to a contribution made by Nakamura and coworkers (Scheme 40) [126]. Chiral allyl palladium species generated from 
bis(imidazoline)-palladium pincer catalyst 47 and allyltrimethoxysilanes through transmetalation underwent the allylation reaction with $N$-tert-butoxycarbonyl- $N^{\prime}$-trityl-protected isatin-derived ketimines. Under the optimized reaction conditions, allylation of ketimines with both electron-donating and -withdrawing substituents provided the corresponding products in $84-96 \%$ yields with $82-95 \%$ ee.

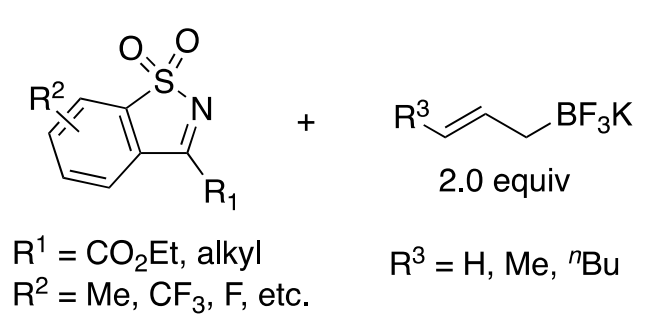

$\mathrm{R}^{2}=\mathrm{Me}, \mathrm{CF}_{3}$, F, etc.

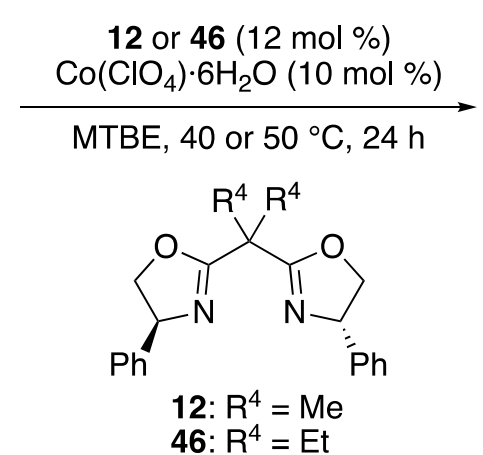

46: $R^{4}=E t$

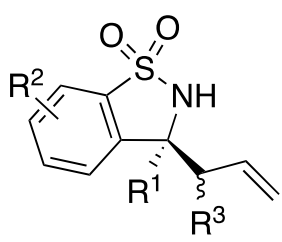

$\mathrm{R}^{1}=\mathrm{CO}_{2} \mathrm{Et}$, ligand 12

20 examples

$78-98 \%$ yields

d.r. $=3: 1$

$53-99 \%$ ee

$\mathrm{R}^{1}=$ alkyl, $\mathrm{R}^{3}=\mathrm{H}$, ligand 46

4 examples

$86-97 \%$ yields

$86-96 \%$ ee

Scheme 39. Enantioselective cobalt-catalyzed allylation of endocyclic ketimines.<smiles></smiles>

$\mathrm{R}^{1}=\mathrm{Me}, \mathrm{MeO}, \mathrm{F}$, etc.

$\mathrm{Bz}=$<smiles>[R]C(=C)C[SiH2]OC</smiles><smiles>COc1cc(C(=O)C(C)(C)C)cc(OC)c1OC</smiles>

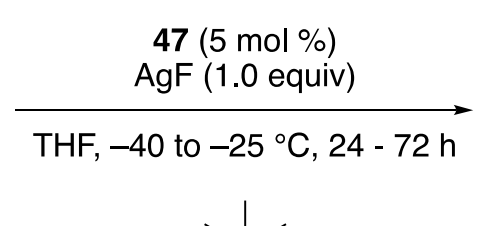

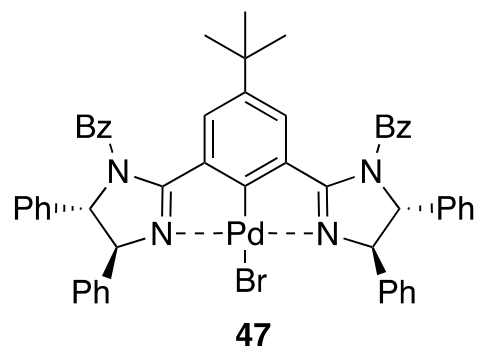<smiles></smiles>

12 examples $84-96 \%$ yields 82 - 95\% ee

Scheme 40. Enantioselective allylation of isatin-derived ketimines catalyzed by a chiral Pd-pincer complex.

\subsubsection{Allyl Bismuth Species}

In 2019, Li and coworkers described the development of an enantioselective asymmetric allylation of isatin-derived ketimines with allylboronates promoted by a binary acid system containing bismuth acetate and chiral phosphoric acid (Scheme 41) [127]. It is notable that most of the ketimines investigated were allylated in less than an hour at room temperature with only $1 \mathrm{~mol} \%$ of $\mathrm{Bi}(\mathrm{OAc})_{3}$ and $2 \mathrm{~mol} \%$ of chiral phosphoric acid 48 . The method gave chiral homoallylic $\alpha$-tertiary amines in 73-99\% yields with 85.1:14.9-99.3:0.7 enantiomeric ratios. An endocyclic $N$-sulfonyl ketiminoester and a pyrazoledione-derived ketimine were included in their study (not shown). While the former was comparable to the isatin-derived ketimines, the latter took $40 \mathrm{~h}$ to provide the corresponding product in $98 \%$ yield with 85.3:14.7 enantiomeric ratio. Regarding the actual nucleophile, they proposed that a chiral allyl bismuth complex generated from allylboronate and two molecules of chiral phosphoric acids through transmetalation would be the allylation species, because the $\alpha$-selectivity was observed with 1-methylalylbornoic acid pinacol ester, and a positive nonlinear effect between the ees of chiral phosphoric acids and products was observed. 
<smiles>[R17]C1OB(CC=C)OC1(C)C</smiles>

$\mathrm{R}^{1}=\mathrm{Me}, \mathrm{MeO}, \mathrm{F}$, etc.

$\mathrm{R}^{2}=\mathrm{H}, \mathrm{Me}, \mathrm{Ph}, \mathrm{Bn}$, etc.

$\mathrm{PG}=\mathrm{Boc}, \mathrm{Cbz}, \mathrm{EtO}_{2} \mathrm{C}, \mathrm{Ph}$

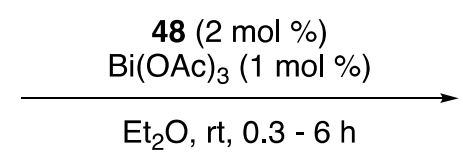

Ar

48<smiles></smiles>

35 examples $73-99 \%$ yields e.r. $=85.1: 14.9$ $-99.5: 0.5$

Scheme 41. Bi(III)-catalyzed enantioselective allylation of ketimines.

\subsubsection{Allenyl Copper Species}

In 2020, Du, Chen, and coworkers reported $\mathrm{Cu}(\mathrm{I})$-catalyzed asymmetric $\alpha$-allenylation of activated ketimines with 3-butynoates (Scheme 42) [128]. Screening of catalysts and reaction conditions was conducted with isatin-derived ketimines. With an optimal catalytic system, $\alpha$-allenylation of fifteen isatin-derived (49), five pyrazoledione-derived (50), four isoquinoline1,2,3-trion-derived (51) ketimines, and one trifluoromethyl alkynyl ketimine (not shown) were evaluated. The first two classes of ketimines underwent the reaction at $-10{ }^{\circ} \mathrm{C}$ and provided the corresponding products after $36 \mathrm{~h}$ in $79-97 \%$ yields with $77-98 \%$ ee, and $64-91 \%$ yields with $84-92 \%$ ee, respectively. In contrast, isoquinoline-1,2,3-trion-derived ketimines took $72 \mathrm{~h}$ at $\mathrm{rt}$ to provide the products in 59-63\% yields with $73-92 \%$ ee. With respect to the actual nucleophile, it was suggested that 3-butynoate generated the corresponding copper enolate intermediate in the presence of DIPEA, which isomerized to $\gamma$-allenyl copper species.

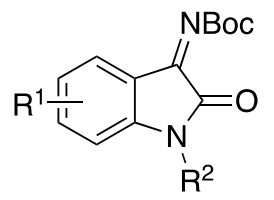<smiles>C#CCC(=O)OCc1ccccc1</smiles>

49: $\mathrm{R}^{1}=\mathrm{Me}, \mathrm{MeO}, \mathrm{F}$, etc. $R^{2}=B n, B o c$

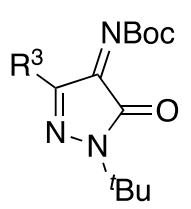

50: $\mathrm{R}^{3}=\mathrm{Me}, \mathrm{Et},{ }^{n} \mathrm{Pr}$, iPr, $\mathrm{Ph}$<smiles>CCC(C)(C)N=C1C(=O)N(Cc2ccccc2)C(=O)c2cc(Br)ccc21</smiles>

51: $\mathrm{R}^{4}=\mathrm{H}, \mathrm{MeO}, \mathrm{F}, \mathrm{Br}$
$18(10 \mathrm{~mol} \%)$

$\mathrm{Cu}\left(\mathrm{CH}_{3} \mathrm{CN}\right)_{4} \mathrm{BF}_{4}(10 \mathrm{~mol} \%)$ $\operatorname{DIPEA}(10 \mathrm{~mol} \%)$

toluene, $-10^{\circ} \mathrm{C}, 36 \mathrm{~h}$<smiles>COc1c(Br)cc(P(c2ccc3c(c2)CCCC3)c2ccc3c(c2-c2c(Br)ccc4c2OCO4)OCO3)cc1Br</smiles>

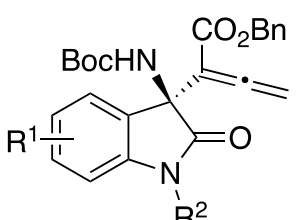

15 examples $79-97 \%$ yields $77-98 \%$ ee

Scheme 42. $\mathrm{Cu}(\mathrm{I})$-catalyzed asymmetric $\alpha$-allenylation of activated ketimines.

\subsubsection{Allyl Gold Species}

In 2021, Hu, Xu, and coworkers developed a gold and chiral organocatalyst cooperative catalysis strategy for the allylation of isatin-derived ketimines with readily available $\mathrm{N}$-propargylamides 52 (Scheme 43) [129]. Their method tolerated various substituents on both substrates and provided the products in 57-96\% yields with 10:1->20:1 diastereoselectivities and $98->99 \%$ ee. As they obtained an X-ray crystal structure of the allyl gold intermediate $\left(55, \mathrm{R}^{3}=\mathrm{Ph}\right)$, they hypothesized that allyl gold species resulted through the aromatization of the corresponding vinyl gold species promoted by a basic functionality of squaramide 53. On this basis, they proposed that the squaramide electrophilically activated a ketimine via dual-hydrogen bonding, while its nitrogen atom coordinated with 
the gold catalyst, leading to a formal intramolecular reaction (i.e., bifunctional catalysis by the squaramide).

(1)<smiles></smiles>
$\mathrm{R}^{1}=\mathrm{Me}, \mathrm{MeO}, \mathrm{F}, \mathrm{Cl}$ etc. $\mathrm{R}^{2}=\mathrm{Bn}, \mathrm{H}, \mathrm{Me}, \mathrm{Ac}$, allyl

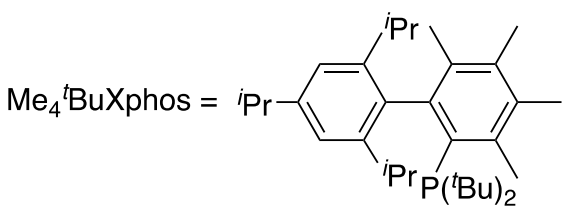
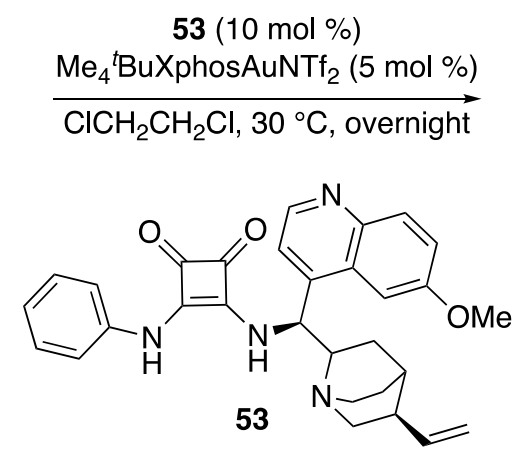<smiles>[R]C1=N[C@H]([C@]2(NC(=O)O)C(=O)N([R7])c3cc[R1]cc32)C(=C)O1</smiles>

37 examples $57-96 \%$ yields d.r. $=10: 1->20: 1$ $98->99 \%$ ee

(2)<smiles>[R]C(=O)NCC#C</smiles>

52<smiles></smiles><smiles>[Y19]C=C1CN=C([R])O1</smiles>

54: vinyl gold

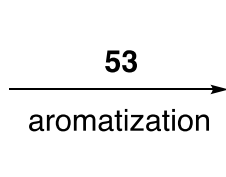

55: "allyl" gold

Scheme 43. Asymmetric allylation of ketimines by allyl gold intermediates promoted by squaramide.

\subsection{Ketimines Bearing a $\mathrm{CF}_{3}$ and/or Carbonyl Moiety etc \\ 4.3.1. Allyl Indium Species}

In 2019, Kürti and coworkers described the first direct catalytic enantioselective allylation of acyclic ketiminoesters to provide $\alpha$-allyl- $\alpha$-aryl and $\alpha$-allyl- $\alpha$-trifluoromethyl amino esters (Scheme 44) [130]. They identified that a complex generated from a commercially available BOX-type ligand (56) and InI as an optimal catalyst for both $\alpha$-aryland $\alpha$-trifluoromethyl- $\alpha$-ketiminoesters. Their method afforded $\alpha$-allyl- $\alpha$-aryl and $\alpha$-allyl$\alpha$-trifluoromethyl amino esters in $85-98 \%$ yields and $95-99 \%$ ee with $5 \mathrm{~mol} \%$ catalyst loading in $\mathrm{CH}_{2} \mathrm{Cl}_{2}$, and $91-99 \%$ yields and $90-99 \%$ ee with $10 \mathrm{~mol} \%$ catalyst loading in THF, respectively. These reactions were scalable to a gram-scale with no deterioration of the yield or enantiopurity. Since an enantiomer of the optimal ligand (56) is not commercially available and would require several steps to synthesize, they found another commercially available ligand $\mathbf{5 7}$ that performed comparably to ligand $\mathbf{5 6}$ with the opposite sense of enantioselection, obtaining the corresponding enantiomers in six $\alpha$-aryl- and three $\alpha$-trifluoromethyl- $\alpha$-ketiminoesters examined.

\subsubsection{Allyl Boronate Species}

In 2020, Hoveyda and coworkers reported a catalytic regio- and enantio-selective synthesis of trifluoromethyl-substituted homoallylic $\alpha$-tertiary primary amines (Scheme 45) [131]. The reaction scope was very broad and included aryl-, heteroaryl-, alkenyl-, and alkynyltrifluoromethyl ketimines, and $\gamma$-substituted Z-allyl and $\beta, \gamma$-trisubstituted Z-allyl boronates. Unprotected $\mathrm{N}-\mathrm{H}$ ketimines generated in situ from corresponding $\mathrm{N}$-silyl ketimines were allylated by an $O$-methyl-L-threonine-derived aminophenol-based boryl catalyst, giving the desired products in 32-91\% yields with 45:55->98:2 $\alpha: \gamma$ selectivity, 95:5->98:2 Z:E selectivity, and 88:12->99:1 enantiomeric ratios. It is worth mentioning that (1) $N$-trimethylsilyl aryl-trifluoromethyl ketimines are stable and readily prepared in multigram quantities and (2) this allylation reaction was demonstrated on a gram-scale with no deterioration of the yield, regio- and stereo-selectivities. 


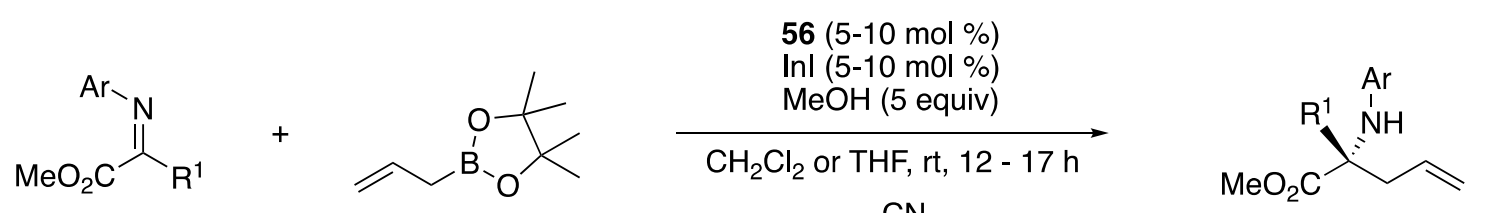

$\mathrm{Ar}=\mathrm{Ph}, 1$-naphthyl, etc

1.5 equiv

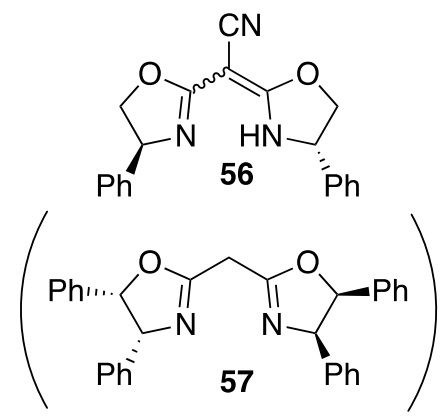

$\mathrm{R}_{1}=$ aryl, 21 examples

$85-98 \%$ yields

$95-99 \%$ ee

$\mathrm{R}_{1}=\mathrm{CF}_{3}, 10$ examples

$91-99 \%$ yields

$90->99 \%$ ee

Scheme 44. Enantioselective catalytic allylation of acyclic ketiminoesters.

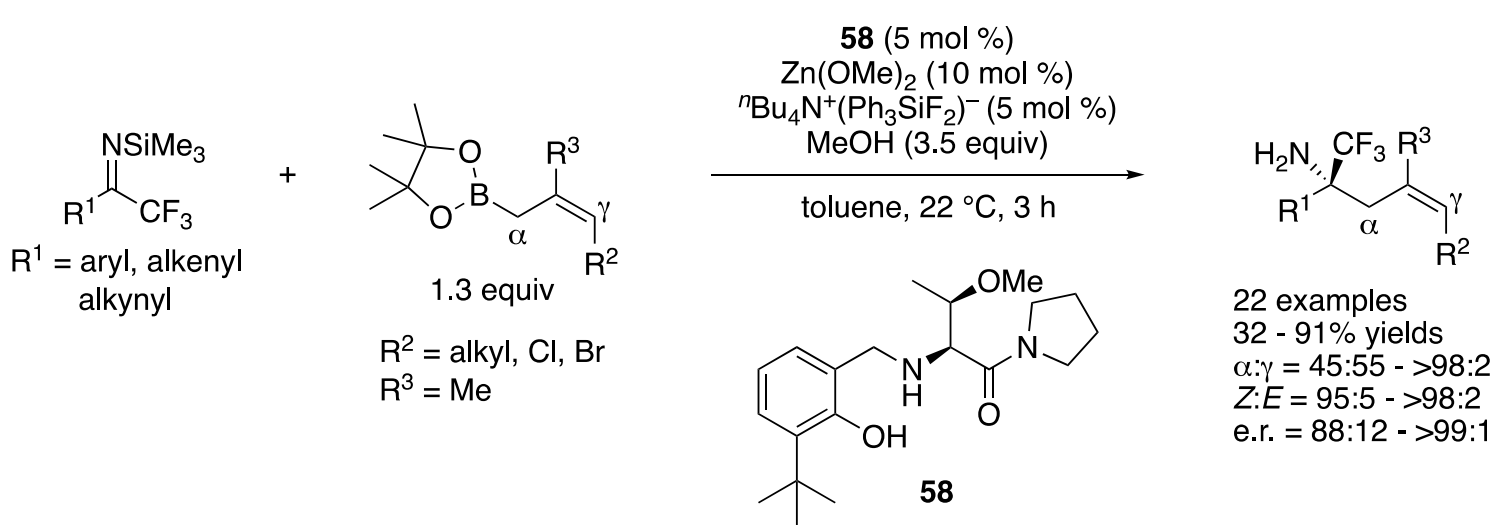

Scheme 45. Regio- and enantio-selective allylation of N-H ketimines generated in situ.

\subsubsection{Allyl Copper Species}

In 2020, Chen and coworkers described an asymmetric allylation of acyclic ketiminoesters through copper-catalyzed carboboronation of allenes (Scheme 46) [132]. They found that the use of a bulky $\mathrm{C}_{2}$-symmetric NHC was the key to control the chemo-, regio-, diastereo-, and enantio-selectivities in their protocol. While the scope of the electrophiles was limited to alkyl aryl glyoxylate-derived ketiminoesters $\left(\mathrm{Ar}^{1}=\operatorname{aryl}\right)$, that of allenes was found broad, affording the products in 53-96\% yields with 4:1->20:1 diastereoselectivities and 75:25-98:2 enantiomeric ratios.

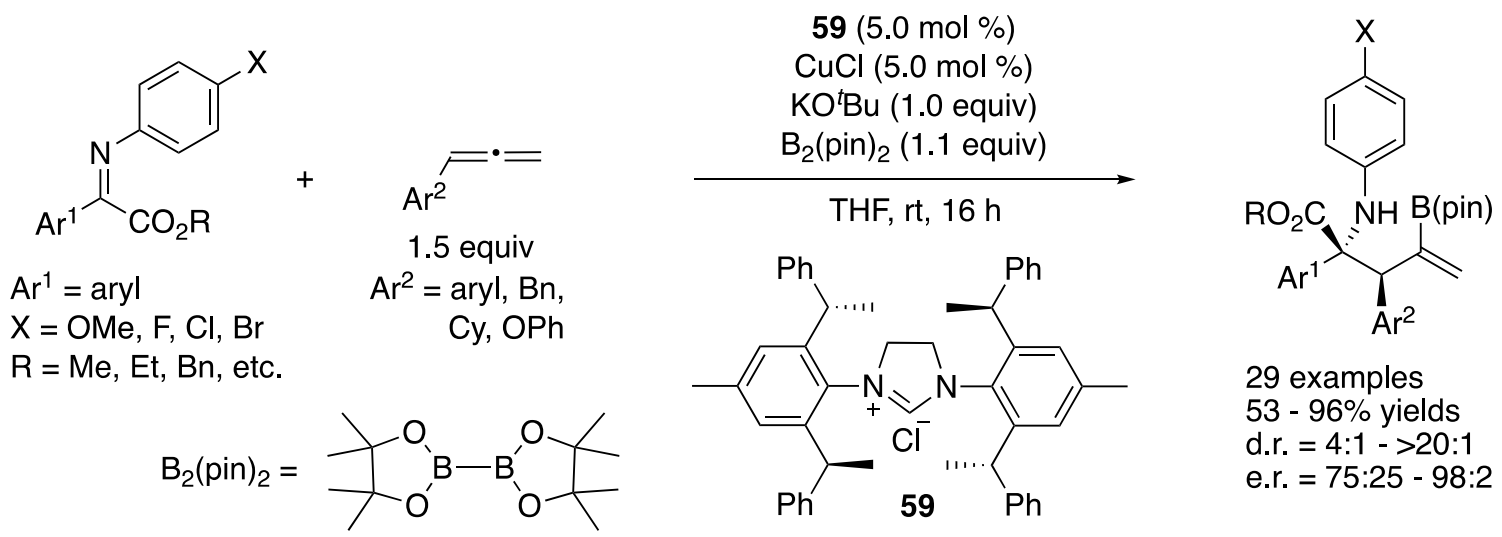

Scheme 46. Enantioselective catalytic allylation of acyclic ketiminoesters via carboboronation of allenes. 


\section{Unmodified Ketimines in the Allylation Reaction \\ 5.1. Allyl Copper Species}

In 2006, Kanai, Shibasaki, and coworkers reported the first catalytic enantioselective ketimine allylation reaction (Scheme 47, (1)) [133]. On the basis of their previous studies on the $\mathrm{Cu}$-catalyzed allylboration of ketones, they hypothesized that a highly nucleophilic allylcopper species generated from allylboronate would also be a suitable nucleophile for ketimines. They first investigated the effect of different ketimine $N$-protecting groups on the reactivity by using achiral $\mathrm{CuF} \cdot 3 \mathrm{PPh}_{3}$ as a catalyst and selected $\mathrm{N}$-benzylketimines for the development of an enantioselective variant. Cyclopentyl-DuPHOS was identified as an optimal chiral ligand for aryl methyl ketimines, providing homoallylic amines in 76-97\% yields with $81-93 \%$ ee. On the other hand, ${ }^{i} \mathrm{Pr}$-DuPHOS was better for an aliphatic ketimine, giving a corresponding homoallylamine in $98 \%$ yield with $23 \%$ ee. The removal of $N$-benzyl group was done in two steps with an overall yield of $88 \%$ (2).

(1)

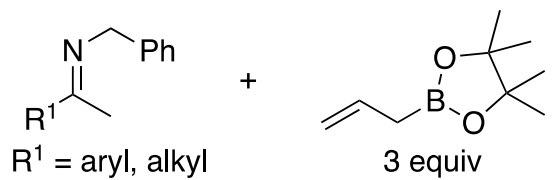

$\mathrm{R}^{1}=$ aryl, alkyl

3 equiv
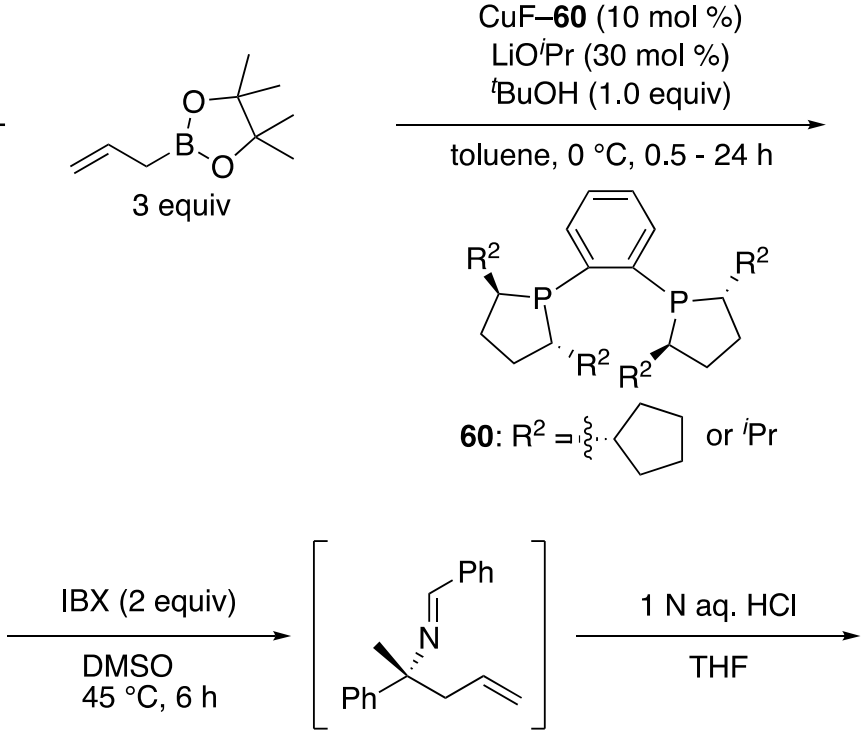

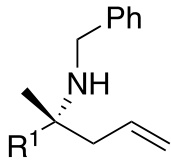

with $\mathrm{R}^{2}=$ cyclopentyl

$\mathrm{R}_{1}=$ aryl, 7 examples

$76-97 \%$ yields

$81-93 \%$ ee

with $\mathrm{R}^{2}={ }^{i} \mathrm{Pr}$

$\mathrm{R}_{1}=\mathrm{CH}_{2} \mathrm{CH}_{2} \mathrm{Ph}$

$98 \%$ yield

$23 \%$ ee
(2)<smiles>C=CCC(C)(NCc1ccccc1)c1ccccc1</smiles>

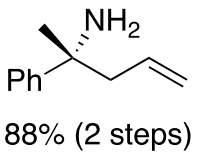

Scheme 47. The first catalytic enantioselective ketimine allylation reaction.

In 2017, Hoveyda and coworkers disclosed the first asymmetric catalytic allylation of unprotected $\mathrm{N}-\mathrm{H}$ ketimines generated in situ from the corresponding salts (61), which directly provided enantio-enriched $\alpha$-tertiary primary amines (Scheme 48) [134]. This class of ketimine salts is bench-stable and prepared by the addition of organo-lithium or magnesium species to readily available nitriles followed by $\mathrm{HCl}$ treatment [32]. This method was not only atom and step economical but also obviated possible complications associated with the removal of $\mathrm{N}$-protecting units in the products. With respect to the actual nucleophiles, the chiral NHC-Cu complex produced corresponding chiral (Z)-allyl copper intermediates through borylcupration of monosubstituted allenes with $\mathrm{B}_{2}(\mathrm{pin})_{2}$, which underwent the addition reaction to $\mathrm{N}-\mathrm{H}$ ketimines. The reaction scope was very broad in terms of both ketimines and allenes, and the primary amine products were obtained in $38-95 \%$ yields with 85.5:14.5->99:1 enantiomeric ratios and exceptional diastereoselectivity (>98:2 throughout). They noted that reactions of ketimines that contained an $\alpha$ - or $\beta$ alkoxy or a benzyl group were inefficient, probably due to facile decomposition (enamine formation and $\beta$-elimination, respectively) and that the same applied to trifluoromethylsubstituted ketimines (decomposition to unidentified products). This catalytic method puts forward an expeditious strategy for the synthesis of $\alpha$-tertiary homoallylamines ( $\beta$ tertiary-amino carbonyl equivalents) with a very broad substrate scope in high diastereoand enantio-selectivities, thus providing a solution to an important and persisting problem 
in catalytic enantioselective synthesis. Indeed, this method is the state of the art in the ketimine allylation.

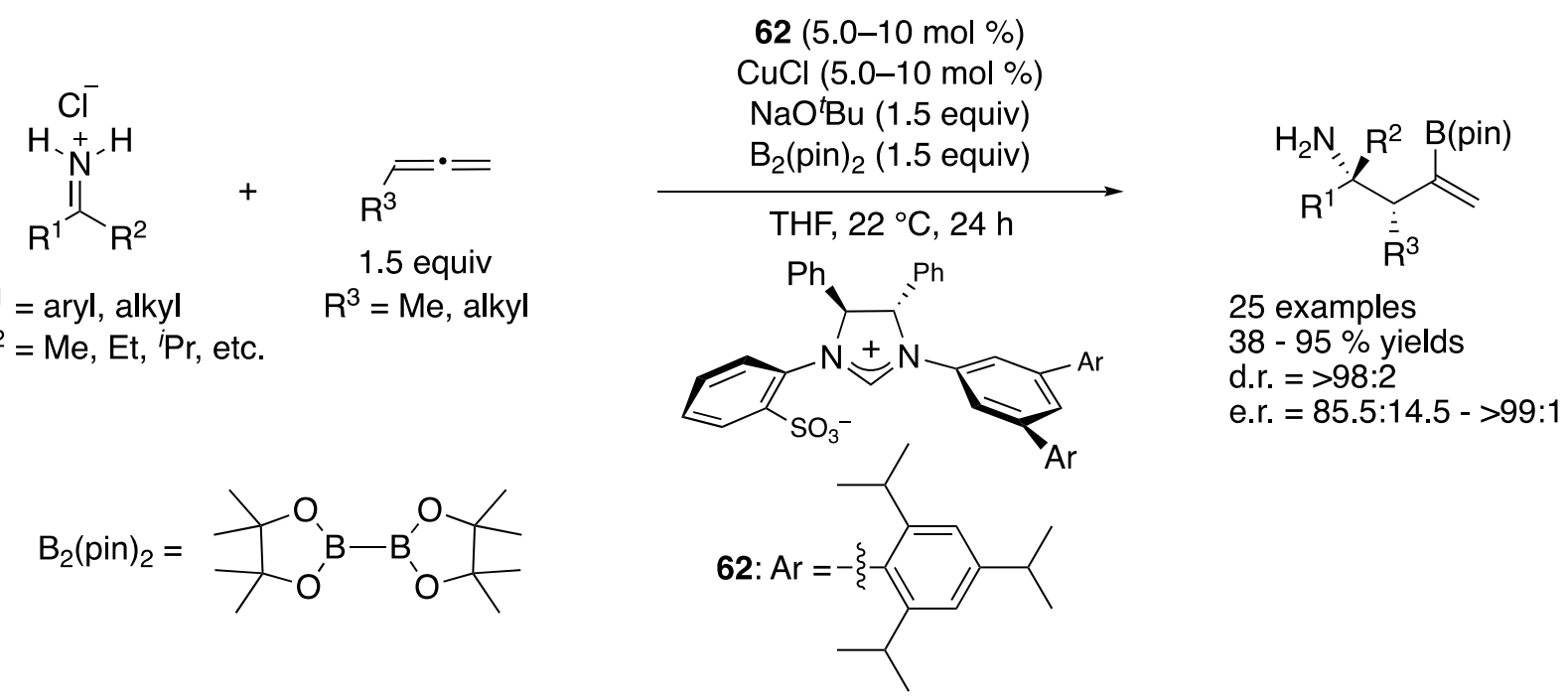

Scheme 48. State-of-the-art catalytic enantioselective allylation of unmodified ketimines.

In 2019, Yun and coworkers described copper-catalyzed asymmetric intramolecular reductive coupling of (E)-dienyl arenes with a tethered ketimine moiety (Scheme 49) [135]. This transformation was a sequence of a chemo-, regio-, and enantio-selective hydrocupration reaction of $(E)$-dienes that produced allyl copper species and their subsequent intramolecular addition to ketimines. The reaction scope was broad and provided enantioenriched 1-benzazepine derivatives bearing two contiguous stereocenters in $11-79 \%$ yields with 75:25-100:0 diastereoselectivities and 63-97\% ee.<smiles>[R7]C(N=CC=C)=Nc1cc#[R]cc1</smiles>

$\mathrm{R}^{1}=\mathrm{Me}, \mathrm{Et}, \mathrm{CO}_{2} \mathrm{Me}$, etc. $\mathrm{R}^{2}=\mathrm{H}, \mathrm{Me}, \mathrm{MeO}, \mathrm{F}$
$(R, R)$-Benzp* $(5 \mathrm{~mol} \%)$ $\mathrm{Cu}(\mathrm{OAc})_{2}(5 \mathrm{~mol} \%)$

${ }^{t} \mathrm{BuOH}(1.5$ equiv) $\mathrm{Me}(\mathrm{EtO})_{2} \mathrm{SiH}$ (2 equiv)

MTBE, $65^{\circ} \mathrm{C}, 12 \mathrm{~h}$<smiles>CCOC(=O)[Pb]=Cc1ccc(P(C)C(C)(C)C)c(P(C)C(C)(C)C)c1</smiles><smiles>[R17]C1C=CC2=CC=[R]#CC=C2NC1[Ga]</smiles>

21 examples $11-79 \%$ yields d.r. $=75: 25-100: 0$ ee $=63-97 \%$

Scheme 49. Catalytic asymmetric intramolecular allylation of ketimines.

\subsection{Pd-Trimethylenemethane (TMM)}

In 2010, Trost and a coworker reported that a zwitterionic complex (Pd-TMM) generated in situ from a Pd catalyst and 1-cyano-2-((trimethylsilyl)methyl)allyl acetate (63) underwent facile cycloaddition reaction with various ketimines (Scheme 50) $[136,137]$. The electrophile scope was very broad and included aryl alkyl, cyclic, and dialkyl ketimines. Phosphoramidite ligand $\mathbf{6 4}$ was found to be optimal for aryl alkyl and cyclic ketimines and provided the corresponding products in 77-99\% yields with 7:1->20:1 diastereoselectivities and $81->99 \%$ ee but gave an unacceptable level of diastereoselectivity for cyclohexyl methyl ketimine. Ligand 65, however, turned out fruitful for dialkyl ketimines, affording the cycloadducts in 50-99\% yields with 1:1->20:1 diastereoselectivities and 84-99\% ee. 


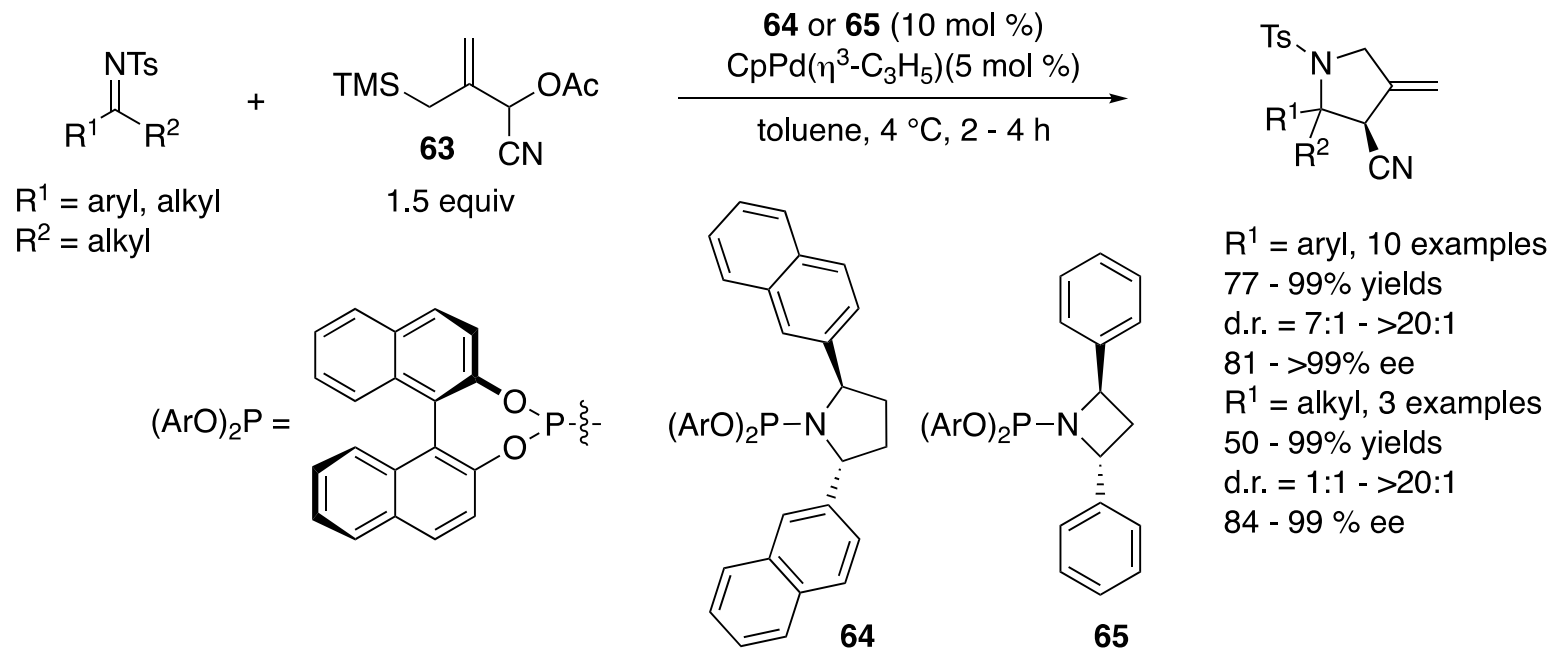

Scheme 50. Pd-catalyzed asymmetric [3+2] cycloaddition of trimethylenemethane with ketimines.

\subsection{Allyl Rhodium Species}

In 2010, Cramer and a coworker reported one example of enantioselective rhodium(I)catalyzed intramolecular allylation of a ketimine (Scheme 51, (1)) [138]. This transformation was initiated by an imine-directed orthorhodation, followed by a carbometallation of the terminal bond of an allene that produced an allyl rhodium species, which in turn underwent an intramolecular ketimine allylation reaction to give the product where its ester group spontaneously cyclized on to the primary amine moiety formed. The absolute configuration of (-)-67 was not determined. In 2013, they extended this protocol to Rh-catalyzed dynamic kinetic resolution of racemic allenes (2) [139]. The substrate scopes of both ketimines and allenes were very broad, affording various cyclic $\alpha$-tertiary homoallylamines in $38-97 \%$ yields with 5:1->20:1 E:Z selectivities and 95:5-99:1 enantiomeric ratios. This protocol also used unprotected $\mathrm{N}-\mathrm{H}$ ketimines that obviated a potentially problematic deprotection of the amine group in the products.

(1)<smiles>C=CCCC(=O)OCC</smiles>

(2)

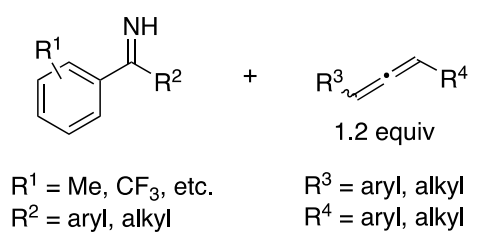

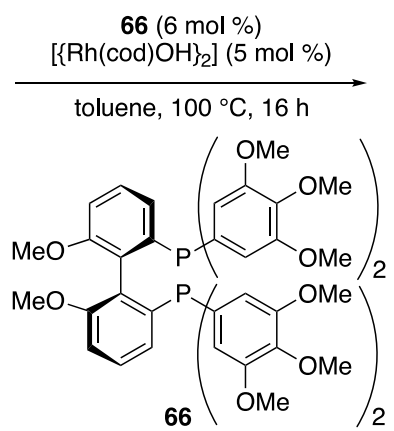

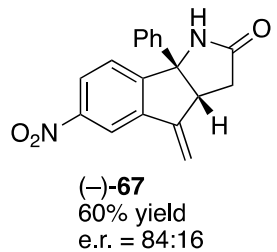

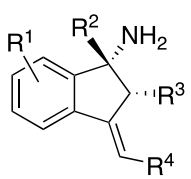

21 examples $38-97 \%$ yields $E: Z=5: 1->20: 1$ e.r. $=95: 5-99: 1$

(R)-BINAP

Scheme 51. Rhodium-catalyzed asymmetric intramolecular allylation of ketimines. 


\subsection{Allyltrichlorosilane}

In 2014, Peng and Takenaka described one example of enantioselective allylation of an aliphatic ketimine with allyltrichlorosilane catalyzed by their helical-chiral Lewis base catalyst (Scheme 52) [140]. Commercially available allyltrichlorosilane is an inexpensive easy-to-use allylation reagent. It is often employed for the allylation of aldehydes and aldimines, but its catalytic enantioselective addition to ketimines is not known to the best of our knowledge. Based on their preliminary mechanistic study, they hypothesized that a product (bearing a $\mathrm{NSiCl}_{3}$ unit before aqueous work-up) inhibited the catalyst from turning over efficiently in $\mathrm{CH}_{2} \mathrm{Cl}_{2}$. A more Lewis basic solvent, THF did improve the catalyst's turnover but adversely affected the enantioselectivity.<smiles>[X][C@H](C)CC=C</smiles><smiles>CC(C)(C)[n+]1ccccc1[O-]</smiles>

$68(30 \mathrm{~mol} \%)$ amylene (2.0 equiv) $-20{ }^{\circ} \mathrm{C}, 16 \mathrm{~h}$

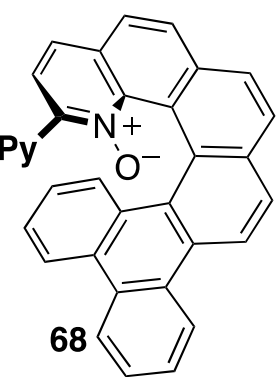

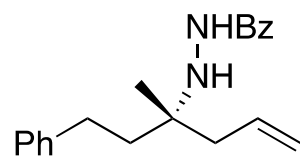

\begin{tabular}{cccc}
\hline $\mathrm{x}$ & solvent & yield (\%) & ee (\%) \\
\hline 1.5 & $\mathrm{CH}_{2} \mathrm{Cl}_{2}$ & 30 & 82 \\
7.5 & $\mathrm{CH}_{2} \mathrm{Cl}_{2}$ & 39 & 84 \\
1.5 & THF & 58 & 71 \\
\hline
\end{tabular}

Scheme 52. Chiral Lewis base-catalyzed allylation of an aliphatic ketimine.

\section{Activated and/or Cyclic Ketimines in Aza-Morita-Baylis-Hillman Reaction}

The asymmetric aza-Morita-Baylis-Hillman (aza-MBH) is widely recognized as a useful and atom-economical carbon-carbon bond formation reaction between electrondeficient alkenes and imines catalyzed by chiral Lewis bases (selected reviews; [141-144]). This transformation provides highly functionalized $\beta$-amino carbonyl compounds in an enantio-enriched form. As such, a number of important developments have been reported. However, the ketimine variant was not known until 2013, in which three independent studies were disclosed [145-147]. One of them employed isatin-derived ketimines [146], and more contributions with isatin-derived ketimines were disclosed later (selected references; [148-154]). In light of the excellent review articles on the isatin-derived ketimines that covered up to the end of 2017 [73-75], we discuss a few selected examples in Section 6.3 (vide infra).

\subsection{Acyclic Ketimines Bearing a Carbonyl Moiety}

In 2013, Chen and coworkers developed an aza-MBH reaction of alkenyl or alkynyl ketiminoesters with acrolein catalyzed by $\beta$-isocupreidine ( $\beta$-ICD) (Scheme 53) [145]. During their optimization study, they found that some double-hydrogen-bond donors such as catechol, $(R)-,(S)$-BINOL, and a chiral thiourea enhanced the enantioselectivity of the model substrate $\left(R^{1}=4-\mathrm{Cl}-\mathrm{Ph}\right)$ from $65 \%$ ee to $87,90,90$, and $90 \%$ ee, respectively, while yields were comparable $(89,92,91,89$, and $91 \%$, respectively). On the basis of the preliminary ${ }^{1} \mathrm{H}$ NMR study of $\beta$-ICD and phenolic additives, they proposed that a BINOL bridged a ketiminoester and a $\beta-\mathrm{ICD}$-acrolein adduct through hydrogen bonding, leading to a more organized transition state. The optimized method worked for both alkenyl- and alkynyl-substituted ketiminoesters and provided the corresponding products in 81-96\% yields with $60-92 \%$ ee and $70-90 \%$ yields with $88-92 \%$ ee, respectively. 
<smiles>[R7]C=CC(=[N+]=[Sn])C(=O)OCC</smiles>

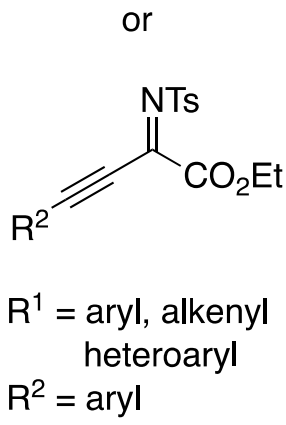<smiles>C=CC=O</smiles>

3 equiv

$\beta-I C D(10 \mathrm{~mol} \%)$

(R)-BINOL (10 $\mathrm{mol} \%)$

THF, $-40^{\circ} \mathrm{C}, 48 \mathrm{~h}$

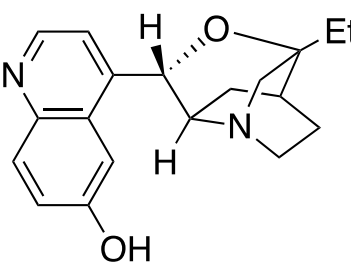

$\beta-I C D$<smiles>Oc1ccc2ccccc2c1-c1c(O)ccc2ccccc12</smiles>

(R)-BINOL<smiles>C=C(C=O)C(C=C[18F])(N[13CH3])C(=O)OCC</smiles>

or<smiles>[R]C#CC(N[AsH2])(C(=C)CO)C(=O)OCC</smiles>

alkenyl product 15 examples $81-96 \%$ yields $60-92 \%$ ee alkynyl product 3 examples $70-90 \%$ yields $88-92 \%$ ee

Scheme 53. The first aza-Morita-Baylis-Hillman reaction of acrolein with ketiminoesters.

In the same year, Jugé and Sasai reported an aza-MBH reaction of methyl or ethyl vinyl ketones with ketiminoesters (Scheme 54) [147]. During their catalyst screening study, they identified that P-chirogenic Lewis bases were superior to other catalysts that were commonly employed for MBH reactions. After optimization of P-chirogenic catalyst structures and other reaction parameters, catalyst 67 provided the MBH products in 59-98\% yields with $41-97 \%$ ee.

$$
\begin{aligned}
& \mathrm{Ar}=\text { aryl, heteroaryl } \\
& \mathrm{R}^{1}=\mathrm{Et}, \mathrm{Bn}, \mathrm{CH}_{2} \mathrm{CF}_{3}
\end{aligned}
$$

$+$<smiles>[R][R3](C)=CC([R7])=O</smiles>

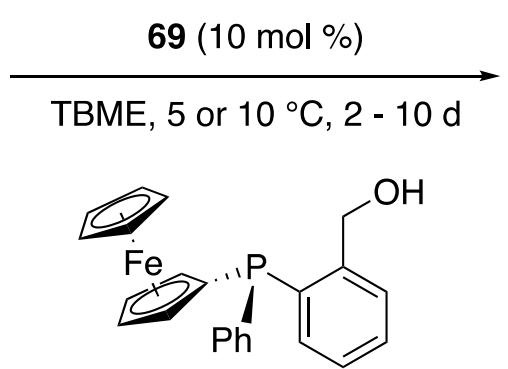

69<smiles>C=C([R]O)C([18O])(Br)C(=O)O</smiles>

10 exmples $59-98 \%$ yields $41-97 \%$ ee

Scheme 54. The P-chirogenic Lewis base-catalyzed aza-MBH reaction of alkyl vinyl ketones with ketiminoesters.

In the same year, Sasai described a chiral Lewis base catalyzed formal [2+2] cycloaddition of ketiminoesters with allenoates (Scheme 55) [155]. This work represents the first example of catalytic enantioselective allenoate addition to ketimines (1). They screened various chiral amines and identified $\beta$-ICD as an optimal catalyst that provided the azetidines in 64-97\% yields with 6:1->20:1 E/Z selectivities and 83-99\% ee. To demonstrate the synthetic utility of the products, they successfully converted an enantio-enriched azetidine to a $\beta$-amino carbonyl compound in two steps without any loss in its optical purity (2).

\subsection{Endocyclic Ketimines}

In 2014, Sasai and coworkers reported enantioselective Lewis base-catalyzed formal [4 + 2] cycloaddition of endocyclic $N$-sulfonyl ketimines with $\alpha$-methyl allenoate (Scheme 56) [156]. After screening commonly used chiral phosphines, they found that (R)-SITCP efficiently promoted the desired transformation. This method readily provided enantio-enriched tetrahydropyridines bearing a chiral tetrasubstituted carbon stereogenic center in $81-95 \%$ yields with $>20: 1$ regioselectivity and $62-92 \%$ ee. With respect to the observed regio- 
selection, they proposed that SITCP (monoaryl spiro-type phosphine catalyst) was relatively electron-rich, thus leading to the kinetically favored $\gamma$-addition to the ketimine through the zwitterionic allenoate-catalyst adduct, followed by intramolecular cyclization.

(1)

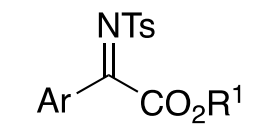

$\operatorname{Ar}=\operatorname{aryl}$

$\mathrm{R}^{1}=\mathrm{Me}, \mathrm{Et}, \mathrm{Bn}$,

$\mathrm{CH}_{2} \mathrm{CF}_{3}$

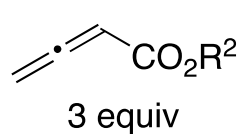

$\mathrm{R}^{2}=\mathrm{Me}, \mathrm{Et}$

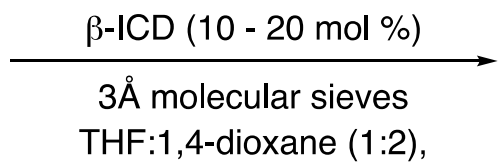

$-5{ }^{\circ} \mathrm{C}, 48 \mathrm{~h}$<smiles></smiles>

$\beta-I C D$

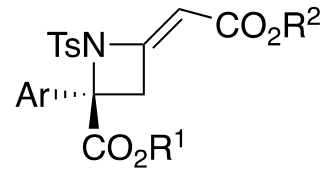

18 examples $64-97 \%$ yields $E: Z=6: 1->20: 1$ $83-99 \%$ ee
(2)

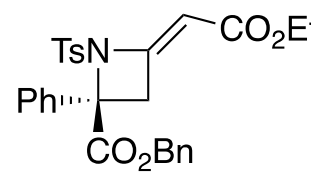

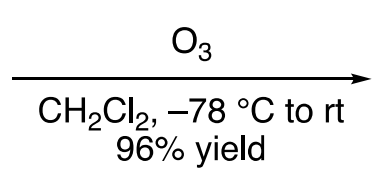

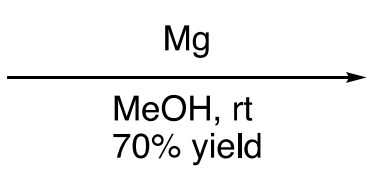

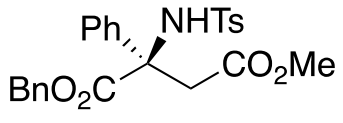

Scheme 55. Chiral Lewis base-catalyzed formal [2 +2] cycloaddition of ketiminoesters with allenoates.<smiles>O=S1(=O)N=C(Br)c2ccccc21</smiles>

$\mathrm{Ar}=$ aryl, heteroaryl $\mathrm{CO}_{2} \mathrm{Et}$<smiles>CCOC(=O)OC(Br)=C(Br)OCC</smiles>

2 equiv

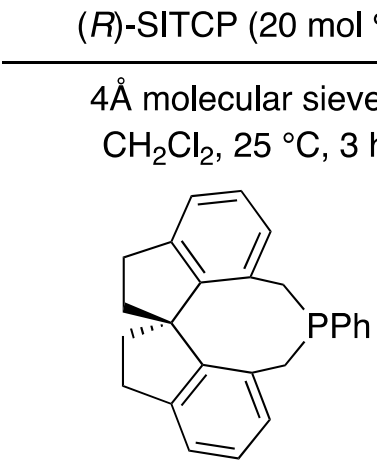

(R)-SITCP<smiles>CCOC(=O)C1=CC([Al])C2([14CH3])c3ccccc3S(=O)(=O)N2C1</smiles>

12 examples $81-95 \%$ yields r.r. $=>20: 1$ $62-92 \%$ ee

Scheme 56. Enantioselective formal [4 +2$]$ cycloaddition of ketimines with $\alpha$-methyl allenoate.

In 2016, Huang and coworkers described a bifunctional-phosphine-catalyzed sequential annulation of endocyclic $N$-sulfonyl ketimines with $\gamma$-benzyl allenoates (Scheme 57) [157]. This transformation readily provided rapid access to polyheterocyclic products with four contiguous stereogenic centers (one quaternary and three tertiary carbon centers). It is noteworthy that only one isomer was obtained in all cases. As to the reaction pathway, it was proposed that a zwitterionic allenoate-catalyst adduct conjugatively added to an $\alpha, \beta$-unsaturated ketimine to generate intermediate $\mathbf{7 1}$, followed by a proton shift and intramolecular addition to the ketimine unit to form the first ring. The method tolerated various aromatic and heteroaromatic substitutions for both substrates and provided the highly complex products in $51-98 \%$ yields with $81-99 \%$ ee. 


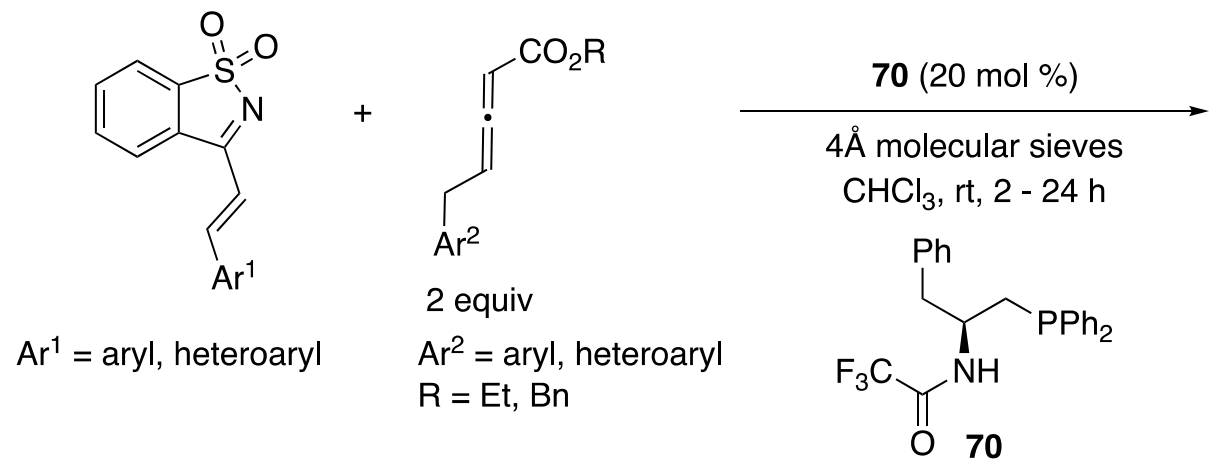

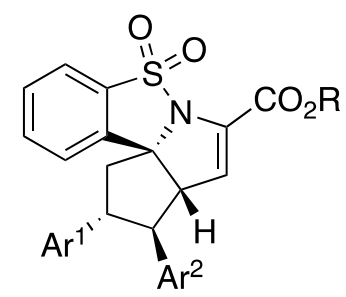

single diastereomers

30 examples

$48-98 \%$ yields

$81-99 \%$ ee

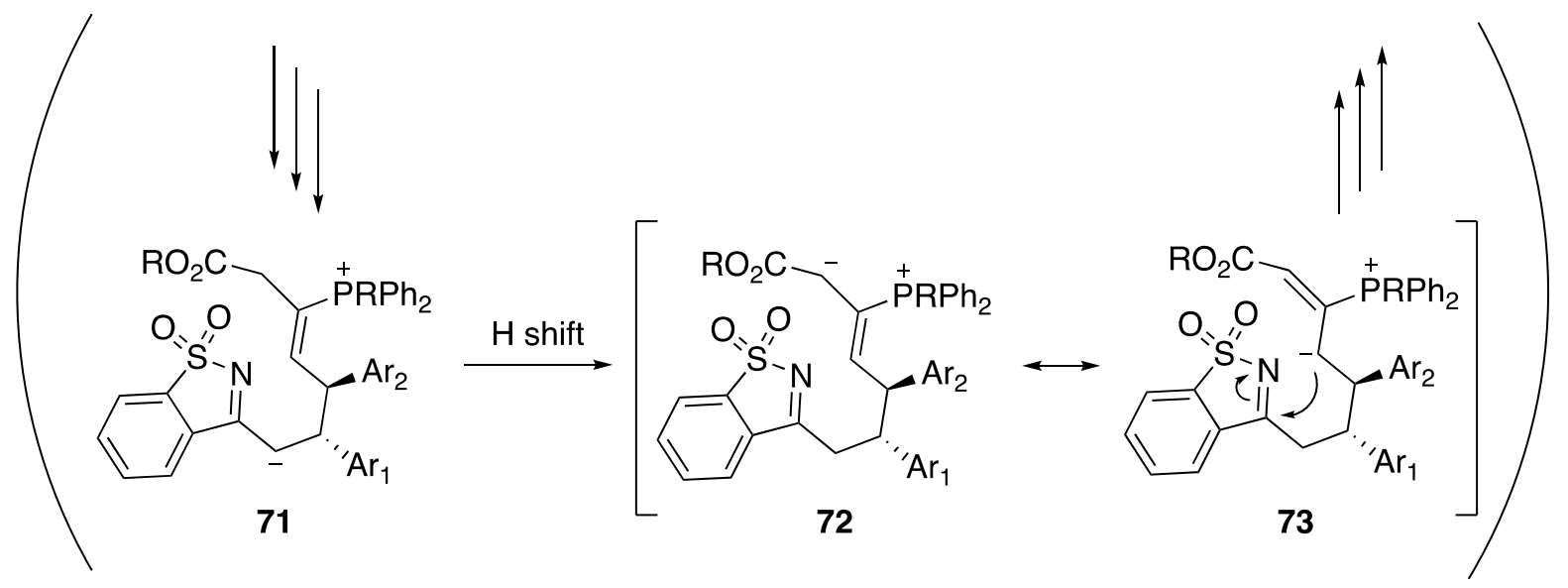

Scheme 57. Chiral phosphine-catalyzed sequential annulation of allenoates and endocyclic ketimines.

\subsection{Isatin-Derived Ketimines}

In 2013, Shi, Li and coworkers described the first catalytic asymmetric aza-MBH reaction of isatin-derived ketimines with methyl vinyl ketone (Scheme 58) [146]. They evaluated both amine- and phosphine-based catalysts ( $\beta$-ICD and 74, respectively) and optimized other reaction parameters for each catalyst. $\beta$-ICD provided the products in $32-98 \%$ yields with $62-94 \%$ ee, and 74 afforded them in $70-97 \%$ yields with $70->99 \%$ ee.<smiles></smiles>

$\mathrm{R}^{1}=\mathrm{Me}, \mathrm{F}, \mathrm{Cl}$ etc $\mathrm{R}^{2}=\mathrm{Bn}, \mathrm{Me}$, allyl<smiles>C=CC(C)=O</smiles>

2 equiv
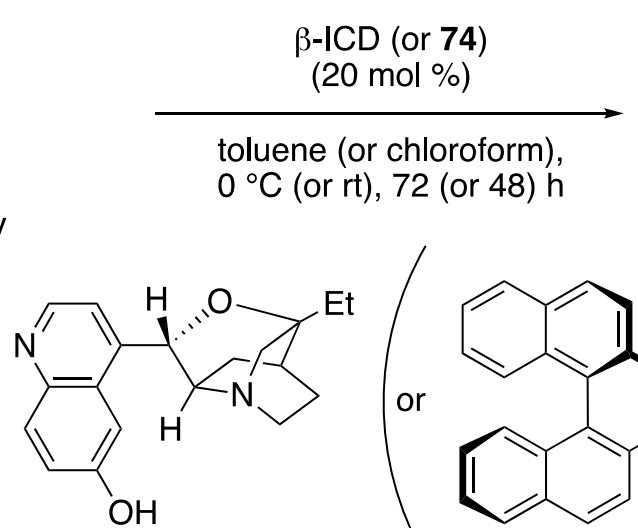

$\beta-I C D$<smiles>Cc1ccc2ccccc2c1-c1c(O)ccc2ccccc12</smiles><smiles></smiles>

with $\beta$-ICD

16 examples

$32-98 \%$ yields

62 - $94 \%$ ee

with 74

16 examples

$70-97 \%$ yields

70 - >99\% ee

Scheme 58. The first asymmetric catalytic aza-MBH reaction of isatin-derived ketimines. 
In 2016, Han, $\mathrm{Lu}$, and coworkers reported an enantioselective phosphine-catalyzed $[3+2]$ annulation reaction of allenoates and isatin-derived ketimines for the first time (Scheme 59) [148]. The method tolerated allenes with both alkyl and aryl substituents at the $\gamma$-positions and afforded various 3,2'-pyrrolidinyl spirooxindoles in $50-85 \%$ yields with

2.3:1-11.2:1 diastereoselectivities and 98.6-99.9\% ee.<smiles>[R]C=C=CC(=O)OCc1ccccc1</smiles>

$\mathrm{R}^{1}=\mathrm{Me}, \mathrm{F}, \mathrm{Cl}$ etc.

\section{2 equiv}

$$
\mathrm{R}^{2}=\mathrm{H} \text {, alkyl, aryl }
$$

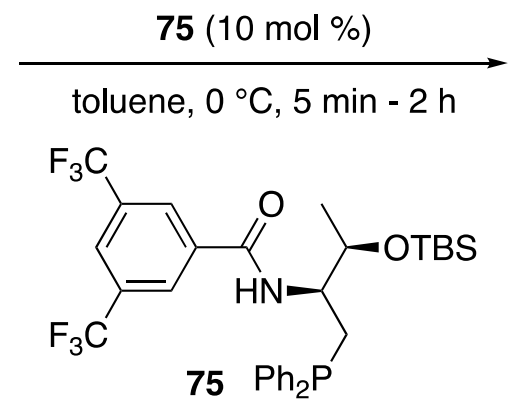

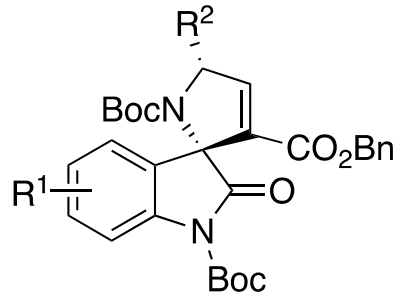

25 examples $50-85 \%$ yields d.r. $=2.3: 1-11.2: 1$ $98.6-99.9 \%$ ee

Scheme 59. A chiral phosphine-catalyzed [3+2] cycloaddition reaction of allenoates and isatin-derived ketimines.

In 2016, Kumar and coworkers disclosed the first diastereo- and enantio-selective [3+2] annulation reaction of $\alpha$-substituted allenoates with isatin-derived ketimines catalyzed by a chiral phosphine (Scheme 60) [149]. They screened various chiral phosphine-based catalysts and found that SITCP provided a desired 3,2'-pyrrolidinyl spiro-oxindole with high selectivities. Under the optimized reaction conditions, the catalyst gave the products in $58-88 \%$ yields with $>99: 1$ diastereoselectivity and $94.3-99.9 \%$ ee.<smiles>[R2]n1c2[cH-][Y17]ccc=2c(=N[R16]([H])([H])C)c1=O</smiles>

$\mathrm{R}^{1}=\mathrm{Me}, \mathrm{F}, \mathrm{Br}$ etc. $\mathrm{R}^{2}=\mathrm{Me}, \mathrm{Ph}$<smiles>[R]CC(=C=C)C(=O)OCC</smiles>

1.2 equiv $\mathrm{R}^{3}=\mathrm{CO}_{2} \mathrm{Et}, \mathrm{CN}$

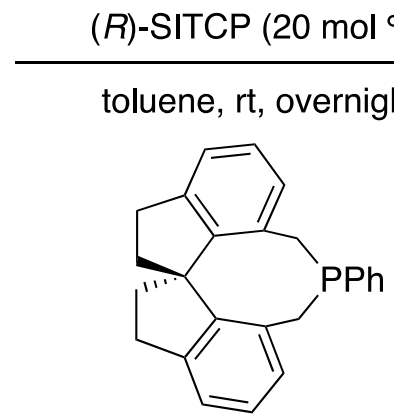

(R)-SITCP

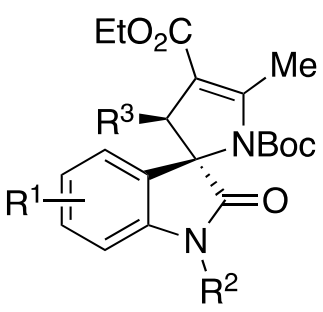

16 examples $58-88 \%$ yields d.r. $=>99: 1$ $94.3-99.9 \%$ ee

Scheme 60. A chiral phosphine-catalyzed [3+2] annulation reaction of $\alpha$-substituted allenoates and isatin-derived ketimines.

\section{Summary and Outlook}

Because of the notorious structural properties of simple ketimines, chemists in general are under the impression that even ketimines with electron-withdrawing substituents are hard to utilize for catalytic asymmetric reactions. Driven by the clear benefits of Mannich reactions, various ketimines have been studied, and many notable achievements are reported in the literature. As such, we hope that these important contributions show that chemists now can readily build $\alpha$-tertiary amine stereogenic centers into molecules of their interest by choosing activated ketimines adequate for their needs. On the other hand, the Mannich and its related reactions of unmodified ketimines currently remain as some of the most important persisting problems in asymmetric catalysis and synthesis, providing intellectually stimulating research opportunities. 
Author Contributions: Manuscript outline-N.T.; bibliographic material selection-C.X., C.R. and N.T.; manuscript writing, review, and editing-C.X., C.R., J.J., B.N., B.C. and N.T. All authors have read and agreed to the published version of the manuscript.

Funding: Support is currently provided by the National Institute of Health (1R15 GM139087-01).

Acknowledgments: We are grateful to our former and present coworkers for their experimental and intellectual contributions to the research program in our laboratory.

Conflicts of Interest: The authors declare no conflict of interest.

\section{References}

1. Mannich, C.; Krösche, W. Ueber ein Kondensationsprodukt aus Formaldehyd, Ammoniak und Antipyrin. Arch. Pharm. 1912, 250, 647-667. [CrossRef]

2. Trost, B.M.; Hung, C.-I.; Mata, G. Dinuclear Metal-ProPhenol Catalysts: Development and Synthetic Applications. Angew. Chem. Int. Ed. 2020, 59, 4240-4261. [CrossRef] [PubMed]

3. Akiyama, T. 6.3 C-C Bond Formation: Mannich Reaction. In Comprehensive Chirality; Elsevier: Amsterdam, The Netherlands, 2012; Volume 6, pp. 69-96. ISBN 9780080951683.

4. Melchiorre, P.; Marigo, M.; Carlone, A.; Bartoli, G. Asymmetric Aminocatalysis-Gold Rush in Organic Chemistry. Angezw. Chem. Int. Ed. 2008, 47, 6138-6171. [CrossRef] [PubMed]

5. Ting, A.; Schaus, S.E. Organocatalytic Asymmetric Mannich Reactions: New Methodology, Catalyst Design, and Synthetic Applications. Eur. J. Org. Chem. 2007, 2007, 5797-5815. [CrossRef]

6. Friestad, G.K.; Mathies, A.K. Recent developments in asymmetric catalytic addition to C=N bonds. Tetrahedron 2007, 63, 2541-2569. [CrossRef]

7. Mukherjee, S.; Yang, J.W.; Hoffmann, S.; List, B. Asymmetric Enamine Catalysis. Chem. Rev. 2007, 107, 5471-5569. [CrossRef] [PubMed]

8. Marques, M.M.B. Catalytic Enantioselective Cross-Mannich Reaction of Aldehydes. Angew. Chem. Int. Ed. 2006, 45, 348-352. [CrossRef] [PubMed]

9. Notz, W.; Tanaka, F.; Barbas, C.F. Enamine-Based Organocatalysis with Proline and Diamines: The Development of Direct Catalytic Asymmetric Aldol, Mannich, Michael, and Diels-Alder Reactions. Acc. Chem. Res. 2004, 37, 580-591. [CrossRef]

10. Córdova, A. The Direct Catalytic Asymmetric Mannich Reaction. Acc. Chem. Res. 2004, 37, 102-112. [CrossRef] [PubMed]

11. Taggi, A.E.; Hafez, A.M.; Lectka, T. $\alpha$-Imino Esters: Versatile Substrates for the Catalytic, Asymmetric Synthesis of $\alpha$ - and $\beta$-Amino Acids and $\beta$-Lactams. Acc. Chem. Res. 2003, 36, 10-19. [CrossRef]

12. Kobayashi, S.; Ishitani, H. Catalytic Enantioselective Addition to Imines. Chem. Rev. 1999, 99, 1069-1094. [CrossRef] [PubMed]

13. Shamna, S.; Afsina, C.M.A.; Philip, R.M.; Anilkumar, G. Recent advances and prospects in the Zn-catalysed Mannich reaction. RSC Adv. 2021, 11, 9098-9111. [CrossRef]

14. Hou, X.; Du, D. Recent Advances in Squaramide-Catalyzed Asymmetric Mannich Reactions. Adv. Synth. Catal. 2020, 362, 4487-4512. [CrossRef]

15. Saranya, S.; Harry, N.A.; Krishnan, K.K.; Anilkumar, G. Recent Developments and Perspectives in the Asymmetric Mannich Reaction. Asian J. Org. Chem. 2018, 7, 613-633. [CrossRef]

16. Frías, M.; Cieślik, W.; Fraile, A.; Rosado-Abón, A.; Garrido-Castro, A.F.; Yuste, F.; Alemán, J. Development and Application of Asymmetric Organocatalytic Mukaiyama and Vinylogous Mukaiyama-Type Reactions. Chem. A Eur. J. 2018, 24, 10906-10933. [CrossRef]

17. Kumagai, N.; Shibasaki, M. Recent Advances in Catalytic Asymmetric C-C Bond-Forming Reactions to Ketimines Promoted by Metal-Based Catalysts. Bull. Chem. Soc. Jpn. 2015, 88, 503-517. [CrossRef]

18. Akiyama, T. 2.16 The Bimolecular and Intramolecular Mannich and Related Reactions. In Comprehensive Organic Synthesis II; Elsevier: Amsterdam, The Netherlands, 2014; Volume 2, pp. 629-681. ISBN 9780080977430.

19. Karimi, B.; Enders, D.; Jafari, E. Recent Advances in Metal-Catalyzed Asymmetric Mannich Reactions. Synthesis 2013, 45, 2769-2812. [CrossRef]

20. Kobayashi, S.; Mori, Y.; Fossey, J.S.; Salter, M.M. Catalytic Enantioselective Formation of C-C Bonds by Addition to Imines and Hydrazones: A Ten-Year Update. Chem. Rev. 2011, 111, 2626-2704. [CrossRef] [PubMed]

21. Matsunaga, S.; Yoshino, T. Construction of Contiguous Tetrasubstituted Chiral Carbon Stereocenters via Direct Catalytic Asymmetric Aldol and Mannich-Type Reactions. Chem. Rec. 2011, 11, 260-268. [CrossRef]

22. Shibasaki, M.; Kanai, M. Asymmetric Synthesis of Tertiary Alcohols and $\alpha$-Tertiary Amines via Cu-Catalyzed C-C Bond Formation to Ketones and Ketimines. Chem. Rev. 2008, 108, 2853-2873. [CrossRef] [PubMed]

23. Riant, O.; Hannedouche, J. Asymmetric catalysis for the construction of quaternary carbon centres: Nucleophilic addition on ketones and ketimines. Org. Biomol. Chem. 2007, 5, 873. [CrossRef]

24. Kano, T.; Aota, Y.; Maruoka, K. Asymmetric Synthesis of Less Accessible $\alpha$-Tertiary Amines from Alkynyl Z- Ketimines. Angew. Chem. Int. Ed. 2017, 56, 16293-16296. [CrossRef] [PubMed] 
25. Kirillova, M.S.; Muratore, M.E.; Dorel, R.; Echavarren, A.M. Concise Total Synthesis of Lundurines A-C Enabled by Gold Catalysis and a Homodienyl Retro-Ene/Ene Isomerization. J. Am. Chem. Soc. 2016, 138, 3671-3674. [CrossRef] [PubMed]

26. Ma, A.; Tu, Y.; Peng, J.; Dou, Q.; Hou, S.; Zhang, F.; Wang, S. Total Synthesis of (-)-FR901483. Org. Lett. 2012, $14,3604-3607$. [CrossRef] [PubMed]

27. Bagutski, V.; Elford, T.G.; Aggarwal, V.K. Synthesis of Highly Enantioenriched C-Tertiary Amines From Boronic Esters: Application to the Synthesis of Igmesine. Angew. Chem. Int. Ed. 2011, 50, 1080-1083. [CrossRef] [PubMed]

28. Edwards, P.D.; Albert, J.S.; Sylvester, M.; Aharony, D.; Andisik, D.; Callaghan, O.; Campbell, J.B.; Carr, R.A.; Chessari, G.; Congreve, M.; et al. Application of Fragment-Based Lead Generation to the Discovery of Novel, Cyclic Amidine $\beta$-Secretase Inhibitors with Nanomolar Potency, Cellular Activity, and High Ligand Efficiency §. J. Med. Chem. 2007, 50, 5912-5925. [CrossRef] [PubMed]

29. Bjørgo, J.; Boyd, D.R.; Watson, C.G.; Jennings, W.B. Equilibrium distribution of E-Z-ketimine isomers. J. Chem. Soc. Perkin Trans. 1974, 2, 757-762. [CrossRef]

30. Berger, R.; Duff, K.; Leighton, J.L. Enantioselective Allylation of Ketone-Derived Benzoylhydrazones: Practical Synthesis of Tertiary Carbinamines. J. Am. Chem. Soc. 2004, 126, 5686-5687. [CrossRef]

31. Yin, Q.; Shi, Y.; Wang, J.; Zhang, X. Direct catalytic asymmetric synthesis of $\alpha$-chiral primary amines. Chem. Soc. Rev. 2020, 49, 6141-6153. [CrossRef] [PubMed]

32. Hou, G.; Gosselin, F.; Li, W.; McWilliams, J.C.; Sun, Y.; Weisel, M.; O'Shea, P.D.; Chen, C.; Davies, I.W.; Zhang, X. Enantioselective Hydrogenation of N-H Imines. J. Am. Chem. Soc. 2009, 131, 9882-9883. [CrossRef] [PubMed]

33. Gröger, H. Catalytic Enantioselective Strecker Reactions and Analogous Syntheses. Chem. Rev. 2003, 103, 2795-2828. [CrossRef] [PubMed]

34. Noble, A.; Anderson, J.C. Nitro-Mannich Reaction. Chem. Rev. 2013, 113, 2887-2939. [CrossRef] [PubMed]

35. Peng, Q.; Guo, D.; Bie, J.; Wang, J. Catalytic Enantioselective Aza-Benzoin Reactions of Aldehydes with $2 H-A z i r i n e s$. Angew. Chem. Int. Ed. 2018, 57, 3767-3771. [CrossRef]

36. Sun, L.-H.; Liang, Z.-Q.; Jia, W.-Q.; Ye, S. Enantioselective N-Heterocyclic Carbene Catalyzed Aza-Benzoin Reaction of Enals with Activated Ketimines. Angew. Chem. Int. Ed. 2013, 52, 5803-5806. [CrossRef]

37. Shen, C.; Wang, R.-Q.; Wei, L.; Wang, Z.-F.; Tao, H.-Y.; Wang, C.-J. Catalytic Asymmetric Umpolung Allylation/2-Aza-Cope Rearrangement for the Construction of $\alpha$-Tetrasubstituted $\alpha$-Trifluoromethyl Homoallylic Amines. Org. Lett. 2019, 21, 6940-6945. [CrossRef] [PubMed]

38. Wang, Y.; Deng, L.-F.; Zhang, X.; Niu, D. Catalytic Asymmetric Synthesis of $\alpha$-Tetrasubstituted $\alpha$-Trifluoromethyl Homoallylic Amines by Ir-Catalyzed Umpolung Allylation of Imines. Org. Lett. 2019, 21, 6951-6956. [CrossRef] [PubMed]

39. Hu, B.; Deng, L. Catalytic Asymmetric Synthesis of Trifluoromethylated $\gamma$-Amino Acids through the Umpolung Addition of Trifluoromethyl Imines to Carboxylic Acid Derivatives. Angew. Chem. Int. Ed. 2018, 57, 2233-2237. [CrossRef] [PubMed]

40. Li, Z.; Hu, B.; Wu, Y.; Fei, C.; Deng, L. Control of chemoselectivity in asymmetric tandem reactions: Direct synthesis of chiral amines bearing nonadjacent stereocenters. Proc. Natl. Acad. Sci. USA 2018, 115, 1730-1735. [CrossRef]

41. Chen, P.; Zhang, J. Phosphine-Catalyzed Asymmetric Synthesis of $\alpha$-Quaternary Amine via Umpolung $\gamma$-Addition of Ketimines to Allenoates. Org. Lett. 2017, 19, 6550-6553. [CrossRef]

42. Chen, P.; Yue, Z.; Zhang, J.; Lv, X.; Wang, L.; Zhang, J. Phosphine-Catalyzed Asymmetric Umpolung Addition of Trifluoromethyl Ketimines to Morita-Baylis-Hillman Carbonates. Angew. Chem. Int. Ed. 2016, 55, 13316-13320. [CrossRef] [PubMed]

43. Wu, Y.; Hu, L.; Li, Z.; Deng, L. Catalytic asymmetric umpolung reactions of imines. Nature 2015, 523, 445-450. [CrossRef] [PubMed]

44. Curto, J.M.; Dickstein, J.S.; Berritt, S.; Kozlowski, M.C. Asymmetric Synthesis of $\alpha$-Allyl- $\alpha$-Aryl $\alpha$-Amino Acids by Tandem Alkylation/ $\pi$-Allylation of $\alpha$-Iminoesters. Org. Lett. 2014, 16, 1948-1951. [CrossRef] [PubMed]

45. Rostoll-Berenguer, J.; Blay, G.; Pedro, J.R.; Vila, C. Asymmetric Oxidative Mannich Reactions. Adv. Synth. Catal. 2021, 363, 602-628. [CrossRef]

46. Saaby, S.; Nakama, K.; Lie, M.A.; Hazell, R.G.; Jørgensen, K.A. The First Catalytic Highly Enantioselective Alkylation of Ketimines-A Novel Approach to Optically Active Quaternary $\alpha$-Amino Acids. Chem. A Eur. J. 2003, 9, 6145-6154. [CrossRef] [PubMed]

47. Zhuang, W.; Saaby, S.; Jørgensen, K.A. Direct Organocatalytic Enantioselective Mannich Reactions of Ketimines: An Approach to Optically Active Quaternary $\alpha$-Amino Acid Derivatives. Angew. Chem. Int. Ed. 2004, 43, 4476-4478. [CrossRef] [PubMed]

48. Kano, T.; Song, S.; Kubota, Y.; Maruoka, K. Highly Diastereo- and Enantioselective Mannich Reactions of Synthetically Flexible Ketimines with Secondary Amine Organocatalysts. Angew. Chem. Int. Ed. 2012, 51, 1191-1194. [CrossRef]

49. Shao, Q.; Wu, L.; Chen, J.; Gridnev, I.D.; Yang, G.; Xie, F.; Zhang, W. Copper (II)/RuPHOX-Catalyzed Enantioselective MannichType Reaction of Glycine Schiff Bases with Cyclic Ketimines. Adv. Synth. Catal. 2018, 360, 4625-4633. [CrossRef]

50. Zhao, M.-X.; Dong, Z.-W.; Zhu, G.-Y.; Zhao, X.-L.; Shi, M. Diastereo- and enantioselective Mannich/cyclization cascade reaction of isocyanoacetates with cyclic sulfamide ketimines by cinchona alkaloid squaramide/AgOAc cooperative catalysis. Org. Biomol. Chem. 2018, 16, 4641-4649. [CrossRef] [PubMed]

51. Zhang, S.; Li, L.; Hu, Y.; Li, Y.; Yang, Y.; Zha, Z.; Wang, Z. Highly Enantioselective Construction of Fluoroalkylated Quaternary Stereocenters via Organocatalytic Dehydrated Mannich Reaction of Unprotected Hemiaminals with Ketones. Org. Lett. 2015, 17, 5036-5039. [CrossRef] 
52. Zhang, S.; Li, L.; Hu, Y.; Zha, Z.; Wang, Z.; Loh, T.-P. Bifunctional Amino Sulfonohydrazide Catalyzed Direct Asymmetric Mannich Reaction of Cyclic Ketimines with Ketones: Highly Diastereo- and Enantioselective Construction of Quaternary Carbon Stereocenters. Org. Lett. 2015, 17, 1050-1053. [CrossRef]

53. Nakamura, S.; Sano, M.; Toda, A.; Nakane, D.; Masuda, H. Organocatalytic Enantioselective Decarboxylative Reaction of Malonic Acid Half Thioesters with Cyclic N-Sulfonyl Ketimines by Using N -Heteroarenesulfonyl Cinchona Alkaloid Amides. Chem. A Eur. J. 2015, 21, 3929-3932. [CrossRef]

54. Qiao, B.; Huang, Y.-J.; Nie, J.; Ma, J.-A. Highly Regio-, Diastereo-, and Enantioselective Mannich Reaction of Allylic Ketones and Cyclic Ketimines: Access to Chiral Benzosultam. Org. Lett. 2015, 17, 4608-4611. [CrossRef] [PubMed]

55. Zhao, M.-X.; Bi, H.-L.; Jiang, R.-H.; Xu, X.-W.; Shi, M. Cinchona Alkaloid Squaramide/AgOAc Cooperatively Catalyzed Diastereoand Enantioselective Mannich/Cyclization Cascade Reaction of Isocyanoacetates and Cyclic Trifluoromethyl Ketimines. Org. Lett. 2014, 16, 4566-4569. [CrossRef] [PubMed]

56. Yuan, H.-N.; Wang, S.; Nie, J.; Meng, W.; Yao, Q.; Ma, J.-A. Hydrogen-Bond-Directed Enantioselective Decarboxylative Mannich Reaction of $\beta$-Ketoacids with Ketimines: Application to the Synthesis of Anti-HIV Drug DPC 083. Angew. Chem. Int. Ed. 2013, 52, 3869-3873. [CrossRef]

57. Jiang, B.; Dong, J.J.; Si, Y.G.; Zhao, X.L.; Huang, Z.G.; Xu, M. Highly Enantioselective Construction of a Quaternary Carbon Center of Dihydroquinazoline by Asymmetric Mannich Reaction and Chiral Recognition. Adv. Synth. Catal. 2008, 350, 1360-1366. [CrossRef]

58. Liu, Q.; Chen, X.-Y.; Li, S.; Jafari, E.; Raabe, G.; Enders, D. N-Heterocyclic carbene-catalyzed [4 + 2] annulation of $\beta$-methyl enals and cyclic trifluoromethyl ketimines for the asymmetric synthesis of dihydroquinazolinone derivatives. Chem. Commun. 2017, 53, 11342-11344. [CrossRef] [PubMed]

59. Luo, Y.; Xie, K.-X.; Yue, D.-F.; Zhang, X.-M.; Xu, X.-Y.; Yuan, W.-C. An organocatalytic asymmetric Mannich reaction of pyrazoleamides with cyclic trifluoromethyl ketimines: Enantioselective access to dihydroquinazolinone skeletons. Org. Biomol. Chem. 2018, 16, 3372-3375. [CrossRef]

60. Li, L.; Han, M.; Xiao, M.; Xie, Z. Proline-Catalyzed Enantioselective Synthesis of Aza-Quaternary Carbon Derivatives. Synlett 2011, 2011, 1727-1730. [CrossRef]

61. Rueping, M.; Rasappan, R.; Raja, S. Asymmetric Proline-Catalyzed Addition of Aldehydes to 3H-Indol-3-ones: Enantioselective Synthesis of 2,3-Dihydro-1H-indol-3-ones with Quaternary Stereogenic Centers. Helv. Chim. Acta 2012, 95, 2296-2303. [CrossRef]

62. Yuan, X.; Wu, X.; Zhang, P.; Peng, F.; Liu, C.; Yang, H.; Zhu, C.; Fu, H. Axially Chiral Cyclic Phosphoric Acid Enabled Enantioselective Sequential Additions. Org. Lett. 2019, 21, 2498-2503. [CrossRef]

63. Xu, Z.; Wang, X.-G.; Wei, Y.-H.; Ji, K.-L.; Zheng, J.-F.; Ye, J.-L.; Huang, P.-Q. Organocatalytic, Enantioselective Reductive Bisfunctionalization of Secondary Amides: One-Pot Construction of Chiral 2,2-Disubstituted 3-Iminoindoline. Org. Lett. 2019, 21, 7587-7591. [CrossRef]

64. Liu, R.-R.; Hu, J.-P.; Hong, J.-J.; Lu, C.-J.; Gao, J.-R.; Jia, Y.-X. Enantioselective [2 + 2] cycloaddition of N-allenamides with cyclic N-sulfonylketimines: Access to polysubstituted azetidines bearing quaternary stereocenters. Chem. Sci. 2017, 8, 2811-2815. [CrossRef] [PubMed]

65. Reddy, K.N.; Rao, M.V.K.; Sridhar, B.; Subba Reddy, B.V. BINOL Phosphoric Acid-Catalyzed Asymmetric Mannich Reaction of Cyclic N-Acyl Ketimines with Cyclic Enones. Chem. Asian J. 2019, 14, 2958-2965. [CrossRef]

66. Wang, Y.-Q.; Zhang, Y.; Pan, K.; You, J.; Zhao, J. Direct Organocatalytic Asymmetric Mannich Addition of 3-Substituted-2 H-1,4-Benzoxazines: Access to Tetrasubstituted Carbon Stereocenters. Adv. Synth. Catal. 2013, 355, 3381-3386. [CrossRef]

67. Wu, L.-L.; Xiang, Y.; Yang, D.-C.; Guan, Z.; He, Y.-H. Biocatalytic asymmetric Mannich reaction of ketimines using wheat germ lipase. Catal. Sci. Technol. 2016, 6, 3963-3970. [CrossRef]

68. Khlebnikov, A.F.; Novikov, M.S. Recent advances in 2H-azirine chemistry. Tetrahedron 2013, 69, 3363-3401. [CrossRef]

69. Hu, H.; Xu, J.; Liu, W.; Dong, S.; Lin, L.; Feng, X. Copper-Catalyzed Asymmetric Addition of Tertiary Carbon Nucleophiles to 2H -Azirines: Access to Chiral Aziridines with Vicinal Tetrasubstituted Stereocenters. Org. Lett. 2018, 20, 5601-5605. [CrossRef] [PubMed]

70. Zhang, H.-J.; Xie, Y.-C.; Yin, L. Copper(I)-catalyzed asymmetric decarboxylative Mannich reaction enabled by acidic activation of 2H-azirines. Nat. Commun. 2019, 10, 1699. [CrossRef]

71. Trost, B.M.; Zhu, C. Zn-ProPhenol Catalyzed Enantioselective Mannich Reaction of 2H-Azirines with Alkynyl Ketones. Org. Lett. 2020, 22, 9683-9687. [CrossRef]

72. Rong, M.-Y.; Li, J.-S.; Zhou, Y.; Zhang, F.-G.; Ma, J.-A. Catalytic Enantioselective Synthesis of Difluoromethylated Tetrasubstituted Stereocenters in Isoindolones Enabled by a Multiple-Fluorine System. Org. Lett. 2020, 22, 9010-9015. [CrossRef]

73. Mohammadi Ziarani, G.; Moradi, R.; Lashgari, N. Asymmetric synthesis of chiral oxindoles using isatin as starting material. Tetrahedron 2018, 74, 1323-1353. [CrossRef]

74. Kaur, J.; Chimni, S.S. Catalytic synthesis of 3-aminooxindoles via addition to isatin imine: An update. Org. Biomol. Chem. 2018, 16, 3328-3347. [CrossRef]

75. Chauhan, P.; Chimni, S.S. Organocatalytic asymmetric synthesis of 3-amino-2-oxindole derivatives bearing a tetra-substituted stereocenter. Tetrahedron Asymmetry 2013, 24, 343-356. [CrossRef]

76. Nakamura, S.; Matsuzaka, K.; Hatanaka, T.; Funahashi, Y. Enantioselective Vinylogous Mannich Reaction of Acyclic Vinylketene Silyl Acetals with Ketimines Using Chiral Bis(imidazoline)-Cu(II) Catalysts. Org. Lett. 2020, 22, 2868-2872. [CrossRef] [PubMed] 
77. Yu, J.-S.; Noda, H.; Kumagai, N.; Shibasaki, M. Direct Catalytic Asymmetric Mannich-Type Reaction of an $\alpha-\mathrm{CF}_{3}$ Amide to Isatin Imines. Synlett 2019, 30, 488-492. [CrossRef]

78. Fan, Y.; Lu, J.; Sha, F.; Li, Q.; Wu, X.-Y. Cu(I)-Catalyzed Asymmetric Mannich Reaction of Glycine Schiff Bases to Ketimines. J. Org. Chem. 2019, 84, 11639-11648. [CrossRef]

79. Franc, M.; Urban, M.; Císařová, I.; Veselý, J. Highly enantioselective addition of sulfur-containing heterocycles to isatin-derived ketimines. Org. Biomol. Chem. 2019, 17, 7309-7314. [CrossRef]

80. Chang, Z.; Ye, C.; Fu, J.; Chigumbu, P.; Zeng, X.; Wang, Y.; Jiang, C.; Han, X. Enantioselective Synthesis of Oxindole-Derived $\alpha$-Aryl- $\beta$-Amino Acid Derivatives and $\delta$-Lactams with Homophthalic Anhydrides. Adv. Synth. Catal. 2019, 361, 5516-5520. [CrossRef]

81. Rodríguez-Ferrer, P.; Sanz-Novo, M.; Maestro, A.; Andrés, J.M.; Pedrosa, R. Synthesis of Enantioenriched 3-Amino-3-Substituted Oxindoles by Stereoselective Mannich Reaction Catalyzed by Supported Bifunctional Thioureas. Adv. Synth. Catal. 2019, 361, 3645-3655. [CrossRef]

82. Lu, J.; Fan, Y.; Sha, F.; Li, Q.; Wu, X.-Y. Copper-catalyzed enantioselective Mannich reaction between N-acylpyrazoles and isatin-derived ketimines. Org. Chem. Front. 2019, 6, 2687-2691. [CrossRef]

83. Huang, Q.; Cheng, Y.; Yuan, H.; Chang, X.; Li, P.; Li, W. Organocatalytic enantioselective Mannich-type addition of 5H-thiazol-4ones to isatin-derived imines: Access to 3-substituted 3-amino-2-oxindoles featured by vicinal sulfur-containing tetrasubstituted stereocenters. Org. Chem. Front. 2018, 5, 3226-3230. [CrossRef]

84. Liu, Y.; Wang, J.; Wei, Z.; Cao, J.; Liang, D.; Lin, Y.; Duan, H. Direct enantio- and diastereoselective Mannich reactions of isatin-derived ketimines with oxo-indanecarboxylates catalyzed by chiral thiourea derived from hydroquinidine. Org. Biomol. Chem. 2018, 16, 8927-8932. [CrossRef]

85. Sawa, M.; Miyazaki, S.; Yonesaki, R.; Morimoto, H.; Ohshima, T. Catalytic Enantioselective Decarboxylative Mannich-Type Reaction of N -Unprotected Isatin-Derived Ketimines. Org. Lett. 2018, 20, 5393-5397. [CrossRef] [PubMed]

86. Newhouse, T.; Baran, P.S.; Hoffmann, R.W. The economies of synthesis. Chem. Soc. Rev. 2009, 38, 3010. [CrossRef] [PubMed]

87. Wender, P.A.; Verma, V.A.; Paxton, T.J.; Pillow, T.H. Function-oriented synthesis, step economy, and drug design. Acc. Chem. Res. 2008, 41, 40-49. [CrossRef]

88. Trost, B. The atom economy-a search for synthetic efficiency. Science 1991, 254, 1471-1477. [CrossRef] [PubMed]

89. Ding, R.; De los Santos, Z.A.; Wolf, C. Catalytic Asymmetric Mannich Reaction of $\alpha$-Fluoronitriles with Ketimines: Enantioselective and Diastereodivergent Construction of Vicinal Tetrasubstituted Stereocenters. ACS Catal. 2019, 9, 2169-2176. [CrossRef]

90. Kang, T.; Hou, L.; Ruan, S.; Cao, W.; Liu, X.; Feng, X. Lewis acid-catalyzed asymmetric reactions of $\beta, \gamma$-unsaturated 2-acyl imidazoles. Nat. Commun. 2020, 11, 3869. [CrossRef]

91. Kang, T.; Cao, W.; Hou, L.; Tang, Q.; Zou, S.; Liu, X.; Feng, X. Chiral Zinc(II)-Catalyzed Enantioselective Tandem $\alpha$-Alkenyl Addition/Proton Shift Reaction of Silyl Enol Ehters with Ketimines. Angew. Chem. Int. Ed. 2019, 58, 2464-2468. [CrossRef] [PubMed]

92. Takeda, T.; Kondoh, A.; Terada, M. Construction of Vicinal Quaternary Stereogenic Centers by Enantioselective Direct MannichType Reaction Using a Chiral Bis(guanidino)iminophosphorane Catalyst. Angew. Chem. Int. Ed. 2016, 55, 4734-4737. [CrossRef] [PubMed]

93. Lin, S.; Kumagai, N.; Shibasaki, M. Direct Catalytic Asymmetric Mannich-type Reaction of $\alpha, \beta$-Unsaturated $\gamma$-Butyrolactam with Ketimines. Chem. A Eur. J. 2016, 22, 3296-3299. [CrossRef] [PubMed]

94. Sawa, M.; Morisaki, K.; Kondo, Y.; Morimoto, H.; Ohshima, T. Direct Access to N-Unprotected $\alpha$ - and/or $\beta$-Tetrasubstituted Amino Acid Esters via Direct Catalytic Mannich-Type Reactions Using N-Unprotected Trifluoromethyl Ketimines. Chem. A Eur. J. 2017, 23, 17022-17028. [CrossRef] [PubMed]

95. Trost, B.M.; Hung, C.-I.J.; Scharf, M.J. Direct Catalytic Asymmetric Vinylogous Additions of $\alpha, \beta-$ and $\beta, \gamma$-Butenolides to Polyfluorinated Alkynyl Ketimines. Angew. Chem. Int. Ed. 2018, 57, 11408-11412. [CrossRef] [PubMed]

96. Dai, J.; Wang, Z.; Deng, Y.; Zhu, L.; Peng, F.; Lan, Y.; Shao, Z. Enantiodivergence by minimal modification of an acyclic chiral secondary aminocatalyst. Nat. Commun. 2019, 10, 5182. [CrossRef]

97. Homma, C.; Takeshima, A.; Kano, T.; Maruoka, K. Construction of chiral $\alpha$ - tert -amine scaffolds via amine-catalyzed asymmetric Mannich reactions of alkyl-substituted ketimines. Chem. Sci. 2021, 12, 1445-1450. [CrossRef]

98. Suto, Y.; Kanai, M.; Shibasaki, M. Catalytic Enantioselective Mannich-type Reactions of Ketoimines. J. Am. Chem. Soc. 2007, 129, 500-501. [CrossRef]

99. Hayashi, M.; Sano, M.; Funahashi, Y.; Nakamura, S. Cinchona Alkaloid Amide/Copper(II) Catalyzed Diastereo- and Enantioselective Vinylogous Mannich Reaction of Ketimines with Siloxyfurans. Angew. Chem. Int. Ed. 2013, 52, 5557-5560. [CrossRef]

100. Du, Y.; Xu, L.-W.; Shimizu, Y.; Oisaki, K.; Kanai, M.; Shibasaki, M. Asymmetric Reductive Mannich Reaction to Ketimines Catalyzed by a Cu(I) Complex. J. Am. Chem. Soc. 2008, 130, 16146-16147. [CrossRef] [PubMed]

101. Reep, C. Development of Axial-Chiral Lewis Base Catalysts for Asymmetric Synthesis. Ph.D. Thesis, Florida Institute of Technology, Melbourne, FL, USA, July 2021. (in preparation) Experimental Data: A round-bottom flask with a stir bar was flame-dried then charged with (R)-3,3'-bis(4-methylphenyl)-1,1'-biisoquinoline $N, N^{\prime}$-dioxide (12 mg, $0.025 \mathrm{mmol}$ ), activated $4 \AA$ molecular sieves powder $(250 \mathrm{mg}, \mathrm{g} / \mathrm{mmol})$ and $\mathrm{CH}_{2} \mathrm{Cl}_{2}$ freshly distilled over $\mathrm{CaH}_{2}(750 \mu \mathrm{L})$. The mixture was stirred for $1 \mathrm{~h}$ at $\mathrm{rt}$, cooled to $-78{ }^{\circ} \mathrm{C}$ and then treated with a solution of trichlorosilane freshly distilled over $\mathrm{CaH}_{2}(51 \mu \mathrm{L}, 0.5 \mathrm{mmol})$ in $\mathrm{CH}_{2} \mathrm{Cl}_{2}$ $(125 \mu \mathrm{L})$. The resulting solution was stirred for $15 \mathrm{~min}$ at $-78{ }^{\circ} \mathrm{C}$. $\mathrm{N}, \mathrm{N}$-Dimethylacrylamide that was distilled over $\mathrm{CaH}_{2}$ and 
stored in a Schlenk flask over 4 Å molecular sieves $(26 \mu \mathrm{L}, 0.25 \mathrm{mmol})$ was added as a solution in $\mathrm{CH}_{2} \mathrm{Cl}_{2}(125 \mu \mathrm{L})$. The mixture was stirred for $15 \mathrm{~min}$ at $-78{ }^{\circ} \mathrm{C}$ and then treated with a solution of benzylacetone-derived hydrazone ( $\left.33 \mathrm{mg}, 0.124 \mathrm{mmol}\right)$ in $\mathrm{CH}_{2} \mathrm{Cl}_{2}(500 \mu \mathrm{L})$. The reaction mixture was stirred for $16 \mathrm{~h}$ at $-40^{\circ} \mathrm{C}$, then quenched by pouring into saturated $\mathrm{NaHCO}_{3}$ solution cooled to $0{ }^{\circ} \mathrm{C}$. The mixture was filtered into a separatory funnel via a short pad of celite, extracted with $\mathrm{CH}_{2} \mathrm{Cl}_{2}, \mathrm{dried}$ over $\mathrm{Na}_{2} \mathrm{SO}_{4}$, and concentrated In Vacuo. The yields of anti- and syn-31 were determined by ${ }^{1} \mathrm{H}$ NMR using 1,1,2,2-tetrachloroethane $(53 \mu \mathrm{L}, 0.5 \mathrm{mmol})$ as an internal standard in $\mathrm{CDCl}_{3}$ (anti-31, 88\%; syn-31, 8\%), then purified by preparative TLC. anti-31: ${ }^{1} \mathrm{H} \mathrm{NMR}$ $\left(400 \mathrm{MHz} \mathrm{CDCl}_{3}\right) \delta 10.82(\mathrm{br} \mathrm{s}, 1 \mathrm{H}), 7.9-7.88(\mathrm{~m}, 2 \mathrm{H}), 7.47-7.41(\mathrm{~m}, 3 \mathrm{H}), 7.20-7.17(\mathrm{~m}, 2 \mathrm{H}), 7.14-7.10(\mathrm{~m}, 1 \mathrm{H}), 7.05(\mathrm{~d}, J .=6.8 \mathrm{~Hz}$, $2 \mathrm{H}), 5.36(\mathrm{br} \mathrm{s}, 1 \mathrm{H}), 3.10(\mathrm{~s}, 3 \mathrm{H}), 2.99(\mathrm{~s}, 3 \mathrm{H}), 2.95(\mathrm{q}, J .=6.8 \mathrm{~Hz}, 1 \mathrm{H}), 2.71(\mathrm{dt}, J .=4.4,12.8 \mathrm{~Hz}, 1 \mathrm{H}), 2.57(\mathrm{dt}, J .=5.2,12.4, \mathrm{~Hz}, 1 \mathrm{H})$, $1.92(\mathrm{dt}, J .=4.4,12.8 \mathrm{~Hz}, 1 \mathrm{H}), 1.61-1.53(\mathrm{~m}, 1 \mathrm{H}), 1.31(\mathrm{~d}, J .=6.4 \mathrm{~Hz}, 3 \mathrm{H}), 1.30(\mathrm{~s}, 3 \mathrm{H}) ;{ }^{13} \mathrm{C} \mathrm{NMR}\left(100 \mathrm{MHz}, \mathrm{CDCl}_{3}\right) \delta 176.9,162.8$, $142.3,133.4,130.9,128.5,128.5,128.4,126.8,125.7,59.7,44.8,38.5,38.2,36.3,29.9,23.4,13.5$; HRMS (ESI): Exact mass calculated for $\mathrm{C}_{22} \mathrm{H}_{29} \mathrm{~N}_{3} \mathrm{NaO}_{2}{ }^{+}[\mathrm{M}+\mathrm{Na}]^{+}$expected: 390.2152, found: 390.2186; HPLC analysis, e.r. = 51:49, tR (major) 26.7 min, $\mathrm{tR}$ (minor) 35.6 min (Daicel Chiralcel ${ }^{\circledR}$ AS-H with an AS-H guard column, hexane/2-propanol = 80:20, $0.5 \mathrm{~mL} / \mathrm{min}$ ); See ref. 105 for its X-ray crystallographic data for structural analysis.

102. Sugiura, M.; Sato, N.; Kotani, S.; Nakajima, M. Lewis base-catalyzed conjugate reduction and reductive aldol reaction of $\alpha, \beta$-unsaturated ketones using trichlorosilane. Chem. Commun. 2008, 2, 4309. [CrossRef]

103. Sugiura, M.; Sato, N.; Sonoda, Y.; Kotani, S.; Nakajima, M. Diastereo- and Enantioselective Reductive Aldol Reaction with Trichlorosilane Using Chiral Lewis Bases as Organocatalysts. Chem. Asian J. 2010, 5, 478-481. [CrossRef]

104. DePorre, Y.C.; Annand, J.R.; Bar, S.; Schindler, C.S. Lewis-Base-Catalyzed Reductive Aldol Reaction To Access Quaternary Carbons. Org. Lett. 2018, 20, 2580-2584. [CrossRef]

105. Allais, C.; Tsai, A.S.; Nuhant, P.; Roush, W.R. Generation of Stereochemically Defined Tetrasubstituted Enolborinates by 1,4Hydroboration of $\alpha, \beta$-Unsaturated Morpholine Carboxamides with (Diisopinocampheyl)borane. Angew. Chem. Int. Ed. 2013, 52, 12888-12891. [CrossRef] [PubMed]

106. Nuhant, P.; Allais, C.; Roush, W.R. Diisopinocampheylborane-Mediated Reductive Aldol Reactions: Highly Enantio- and Diastereoselective Synthesis of syn Aldols from N -Acryloylmorpholine. Angew. Chem. Int. Ed. 2013, 52, 8703-8707. [CrossRef] [PubMed]

107. Crystallographic Data for the Structural Analysis have been Deposited with the Cambridge Crystallographic Data Centre, CCDC No. 2077332 for Compound 31. Copy of this Information may Be Obtained Free of Charge from, The Director, CCDC 12 Union Road, Cambridge CB2 1EZ, UK. Available online: https: / / www.ccdc.cam.ac.uk/ (accessed on 6 June 2021).

108. Baudequin, C.; Zamfir, A.; Tsogoeva, S.B. Highly enantioselective organocatalytic formation of a quaternary carbon center via chiral Brønsted acid catalyzed self-coupling of enamides. Chem. Commun. 2008, 4637-4639. [CrossRef] [PubMed]

109. Yazaki, R.; Nitabaru, T.; Kumagai, N.; Shibasaki, M. Direct Catalytic Asymmetric Addition of Allylic Cyanides to Ketoimines. J. Am. Chem. Soc. 2008, 130, 14477-14479. [CrossRef] [PubMed]

110. Lu, G.; Yoshino, T.; Morimoto, H.; Matsunaga, S.; Shibasaki, M. Stereodivergent Direct Catalytic Asymmetric Mannich-Type Reactions of $\alpha$-Isothiocyanato Ester with Ketimines. Angew. Chem. Int. Ed. 2011, 50, 4382-4385. [CrossRef] [PubMed]

111. Yin, L.; Takada, H.; Kumagai, N.; Shibasaki, M. Direct Catalytic Asymmetric Vinylogous Mannich-Type Reaction of $\gamma$-Butenolides with Ketimines. Angew. Chem. Int. Ed. 2013, 52, 7310-7313. [CrossRef] [PubMed]

112. Ortín, I.; Dixon, D.J. Direct Catalytic Enantio- and Diastereoselective Mannich Reaction of Isocyanoacetates and Ketimines. Angew. Chem. Int. Ed. 2014, 53, 3462-3465. [CrossRef] [PubMed]

113. Hayashi, M.; Iwanaga, M.; Shiomi, N.; Nakane, D.; Masuda, H.; Nakamura, S. Direct Asymmetric Mannich-Type Reaction of $\alpha$-Isocyanoacetates with Ketimines using Cinchona Alkaloid/Copper(II) Catalysts. Angew. Chem. Int. Ed. 2014, 53, 8411-8415. [CrossRef]

114. De la Campa, R.; Gammack Yamagata, A.D.; Ortín, I.; Franchino, A.; Thompson, A.L.; Odell, B.; Dixon, D.J. Catalytic enantio- and diastereoselective Mannich reaction of $\alpha$-substituted isocyanoacetates and ketimines. Chem. Commun. 2016, 52, 10632-10635. [CrossRef]

115. Nakamura, S.; Yamaji, R.; Iwanaga, M. Enantioselective construction of imidazolines having vicinal tetra-substituted stereocenters by direct Mannich reaction of $\alpha$-substituted $\alpha$-isocyanoacetates with ketimines. Chem. Commun. 2016, 52, 7462-7465. [CrossRef] [PubMed]

116. Lin, S.; Kawato, Y.; Kumagai, N.; Shibasaki, M. Catalytic Asymmetric Mannich-Type Reaction of N-Alkylidene- $\alpha$ Aminoacetonitrile with Ketimines. Angew. Chem. Int. Ed. 2015, 54, 5183-5186. [CrossRef] [PubMed]

117. Nakamura, S.; Yamaji, R.; Hayashi, M. Direct Enantioselective Vinylogous Mannich Reaction of Ketimines with $\gamma$-Butenolide by Using Cinchona Alkaloid Amide/Zinc(II) Catalysts. Chem. A Eur. J. 2015, 21, 9615-9618. [CrossRef]

118. Talbot, F.J.T.; Dherbassy, Q.; Manna, S.; Shi, C.; Zhang, S.; Howell, G.P.; Perry, G.J.P.; Procter, D.J. Copper-Catalyzed Borylative Couplings with C-N Electrophiles. Angew. Chem. Int. Ed. 2020, 59, 20278-20289. [CrossRef] [PubMed]

119. Huo, H.-X.; Duvall, J.R.; Huang, M.-Y.; Hong, R. Catalytic asymmetric allylation of carbonyl compounds and imines with allylic boronates. Org. Chem. Front. 2014, 1, 303-320. [CrossRef]

120. Yus, M.; González-Gómez, J.C.; Foubelo, F. Catalytic Enantioselective Allylation of Carbonyl Compounds and Imines. Chem. Rev. 2011, 111, 7774-7854. [CrossRef]

121. Kanai, M.; Wada, R.; Shibuguchi, T.; Shibasaki, M. Cu(I)-catalyzed asymmetric allylation of ketones and ketimines. Pure Appl. Chem. 2008, 80, 1055-1062. [CrossRef] 
122. Luo, Y.; Hepburn, H.B.; Chotsaeng, N.; Lam, H.W. Enantioselective Rhodium-Catalyzed Nucleophilic Allylation of Cyclic Imines with Allylboron Reagents. Angew. Chem. Int. Ed. 2012, 51, 8309-8313. [CrossRef] [PubMed]

123. Hepburn, H.; Chotsaeng, N.; Luo, Y.; Lam, H. Enantioselective Rhodium-Catalyzed Allylation of Cyclic Imines with Potassium Allyltrifluoroborates. Synthesis 2013, 45, 2649-2661. [CrossRef]

124. Hepburn, H.B.; Lam, H.W. The Isomerization of Allylrhodium Intermediates in the Rhodium-Catalyzed Nucleophilic Allylation of Cyclic Imines. Angew. Chem. Int. Ed. 2014, 53, 11605-11610. [CrossRef]

125. Wu, L.; Shao, Q.; Yang, G.; Zhang, W. Cobalt-Catalyzed Asymmetric Allylation of Cyclic Ketimines. Chem. A Eur. J. 2018, 24, 1241-1245. [CrossRef] [PubMed]

126. Nakamura, S.; Hyodo, K.; Nakamura, M.; Nakane, D.; Masuda, H. Catalytic Enantioselective Allylation of Ketimines by Using Palladium Pincer Complexes with Chiral Bis(imidazoline)s. Chem. A Eur. J. 2013, 19, 7304-7309. [CrossRef] [PubMed]

127. Wang, J.; Zhang, Q.; Zhou, B.; Yang, C.; Li, X.; Cheng, J.-P. Bi(III)-Catalyzed Enantioselective Allylation Reactions of Ketimines. Iscience 2019, 16, 511-523. [CrossRef] [PubMed]

128. Ran, G.-Y.; Chen, C.; Yang, X.-X.; Zhao, Z.; Du, W.; Chen, Y.-C. Cu(I)-Catalyzed Asymmetric $\alpha$-Allenylation of Activated Ketimines with 3-Butynoates. Org. Lett. 2020, 22, 4732-4736. [CrossRef]

129. Dong, G.; Bao, M.; Xie, X.; Jia, S.; Hu, W.; Xu, X. Asymmetric Allylation by Chiral Organocatalyst-Promoted Formal Hetero-Ene Reactions of Alkylgold Intermediates. Angew. Chem. Int. Ed. 2021, 60, 1992-1999. [CrossRef] [PubMed]

130. Bhakta, U.; Kattamuri, P.V.; Siitonen, J.H.; Alemany, L.B.; Kürti, L. Enantioselective Catalytic Allylation of Acyclic Ketiminoesters: Synthesis of $\alpha$-Fully-Substituted Amino Esters. Org. Lett. 2019, 21, 9208-9211. [CrossRef]

131. Fager, D.C.; Morrison, R.J.; Hoveyda, A.H. Regio- and Enantioselective Synthesis of Trifluoromethyl-Substituted Homoallylic $\alpha$-Tertiary $\mathrm{NH}_{2}$-Amines by Reactions Facilitated by a Threonine-Based Boron-Containing Catalyst. Angew. Chem. Int. Ed. 2020, 59, 11448-11455. [CrossRef] [PubMed]

132. Zhao, C.-Y.; Zheng, H.; Ji, D.-W.; Min, X.-T.; Hu, Y.-C.; Chen, Q.-A. Copper-Catalyzed Asymmetric Carboboronation of Allenes to Access $\alpha$-Quaternary Amino Esters with Adjacent Stereocenters. Cell Rep. Phys. Sci. 2020, 1, 100067. [CrossRef]

133. Wada, R.; Shibuguchi, T.; Makino, S.; Oisaki, K.; Kanai, M.; Shibasaki, M. Catalytic Enantioselective Allylation of Ketoimines. J. Am. Chem. Soc. 2006, 128, 7687-7691. [CrossRef] [PubMed]

134. Jang, H.; Romiti, F.; Torker, S.; Hoveyda, A.H. Catalytic diastereo- and enantioselective additions of versatile allyl groups to N-H ketimines. Nat. Chem. 2017, 9, 1269-1275. [CrossRef]

135. Li, D.; Park, Y.; Yoon, W.; Yun, H.; Yun, J. Asymmetric Synthesis of 1-Benzazepine Derivatives via Copper-Catalyzed Intramolecular Reductive Cyclization. Org. Lett. 2019, 21, 9699-9703. [CrossRef] [PubMed]

136. Trost, B.M.; Stambuli, J.P.; Silverman, S.M.; Schwörer, U. Palladium-Catalyzed Asymmetric [3 + 2] Trimethylenemethane Cycloaddition Reactions. J. Am. Chem. Soc. 2006, 128, 13328-13329. [CrossRef] [PubMed]

137. Trost, B.M.; Silverman, S.M. Enantioselective Construction of Highly Substituted Pyrrolidines by Palladium-Catalyzed Asymmetric [3+2] Cycloaddition of Trimethylenemethane with Ketimines. J. Am. Chem. Soc. 2010, 132, 8238-8240. [CrossRef] [PubMed]

138. Tran, D.N.; Cramer, N. syn-Selective Rhodium(I)-Catalyzed Allylations of Ketimines Proceeding through a Directed C-H Activation/Allene Addition Sequence. Angew. Chem. Int. Ed. 2010, 49, 8181-8184. [CrossRef]

139. Tran, D.N.; Cramer, N. Rhodium-Catalyzed Dynamic Kinetic Asymmetric Transformations of Racemic Allenes by the [3+2] Annulation of Aryl Ketimines. Angew. Chem. Int. Ed. 2013, 52, 10630-10634. [CrossRef]

140. Peng, Z. Development of Helical Chiral Catalysts and Their Application in Asymmetric Catalysis. Ph.D. Thesis, University of Miami, Miami, FL, USA, August 2014.

141. Guo, H.; Fan, Y.C.; Sun, Z.; Wu, Y.; Kwon, O. Phosphine Organocatalysis. Chem. Rev. 2018, 118, 10049-10293. [CrossRef] [PubMed]

142. Ni, H.; Chan, W.-L.; Lu, Y. Phosphine-Catalyzed Asymmetric Organic Reactions. Chem. Rev. 2018, 118, 9344-9411. [CrossRef]

143. Pellissier, H. Recent developments in the asymmetric organocatalytic Morita-Baylis-Hillman reaction. Tetrahedron 2017, 73, 2831-2861. [CrossRef]

144. Hu, F.-L.; Shi, M. The highly enantioselective catalytic aza-Morita-Baylis-Hillman reaction. Org. Chem. Front. 2014, 1, 587-595. [CrossRef]

145. Yao, Y.; Li, J.-L.; Zhou, Q.-Q.; Dong, L.; Chen, Y.-C. Enantioselective Aza-Morita-Baylis-Hillman Reaction with Ketimines and Acrolein Catalyzed by Organic Assemblies. Chem. A Eur. J. 2013, 19, 9447-9451. [CrossRef]

146. Hu, F.-L.; Wei, Y.; Shi, M.; Pindi, S.; Li, G. Asymmetric catalytic aza-Morita-Baylis-Hillman reaction for the synthesis of 3-substituted-3-aminooxindoles with chiral quaternary carbon centers. Org. Biomol. Chem. 2013, 11, 1921. [CrossRef] [PubMed]

147. Takizawa, S.; Rémond, E.; Arteaga, F.A.; Yoshida, Y.; Sridharan, V.; Bayardon, J.; Jugé, S.; Sasai, H. P-chirogenic organocatalysts: Application to the aza-Morita-Baylis-Hillman (aza-MBH) reaction of ketimines. Chem. Commun. 2013, 49, 8392. [CrossRef]

148. Han, X.; Chan, W.L.; Yao, W.; Wang, Y.; Lu, Y. Phosphine-mediated highly enantioselective spirocyclization with ketimines as substrates. Angew. Chem. Int. Ed. 2016, 55, 6492-6496. [CrossRef] [PubMed]

149. Sankar, M.G.; Garcia-Castro, M.; Golz, C.; Strohmann, C.; Kumar, K. Engaging Allene-Derived Zwitterions in an Unprecedented Mode of Asymmetric [3+2]-Annulation Reaction. Angew. Chem. Int. Ed. 2016, 55, 9709-9713. [CrossRef] [PubMed]

150. Rainoldi, G.; Faltracco, M.; Spatti, C.; Silvani, A.; Lesma, G. Organocatalytic access to enantioenriched spirooxindole-based 4-methyleneazetidines. Molecules 2017, 22, 2016. [CrossRef] [PubMed] 
151. Kumar, A.; Sharma, V.; Kaur, J.; Kumar, N.; Chimni, S.S. Maleimide as an efficient nucleophilic partner in the aza-Morita-BaylisHillman reaction: Synthesis of chiral 3-substituted-3-aminooxindoles. Org. Biomol. Chem. 2015, 13, 5629-5635. [CrossRef] [PubMed]

152. Yoshida, Y.; Sako, M.; Kishi, K.; Sasai, H.; Hatakeyama, S.; Takizawa, S. An enantioselective organocatalyzed aza-Morita-BaylisHillman reaction of isatin-derived ketimines with acrolein. Org. Biomol. Chem. 2015, 13, 9022-9028. [CrossRef] [PubMed]

153. Zhao, X.; Li, T.-Z.; Qian, J.-Y.; Sha, F.; Wu, X.-Y. Enantioselective aza-Morita-Baylis-Hillman reaction between acrylates and N-Boc isatin ketimines: Asymmetric construction of chiral 3-substituted-3-aminooxindoles. Org. Biomol. Chem. 2014, 12, 8072-8078. [CrossRef] [PubMed]

154. Hirata, S.; Tanaka, K.; Matsui, K.; Arteaga, F.A.; Yoshida, Y.; Takizawa, S.; Sasai, H. Chiral bifunctional organocatalysts bearing a 1,3-propanediamine unit for the aza-MBH reaction. Tetrahedron Asymmetry 2013, 24, 1189-1192. [CrossRef]

155. Takizawa, S.; Arteaga, F.A.; Yoshida, Y.; Suzuki, M.; Sasai, H. Organocatalyzed Formal [2 + 2] Cycloaddition of Ketimines with Allenoates: Facile Access to Azetidines with a Chiral Tetrasubstituted Carbon Stereogenic Center. Org. Lett. 2013, 15, $4142-4145$. [CrossRef]

156. Takizawa, S.; Arteaga, F.A.; Yoshida, Y.; Suzuki, M.; Sasai, H. Enantioselective Organocatalyzed Formal [4 + 2] Cycloaddition of Ketimines with Allenoates: Easy Access to a Tetrahydropyridine Framework with a Chiral Tetrasubstituted Stereogenic Carbon Center. Asian J. Org. Chem. 2014, 3, 412-415. [CrossRef]

157. Li, E.; Jin, H.; Jia, P.; Dong, X.; Huang, Y. Bifunctional-Phosphine-Catalyzed Sequential Annulations of Allenoates and Ketimines: Construction of Functionalized Poly-heterocycle Rings. Angew. Chem. Int. Ed. 2016, 55, 11591-11594. [CrossRef] [PubMed] 